\title{
Geomorphic Evidence of Deformation in the Northern Part of the \\ New Madrid Seismic Zone
}

U.S. GEOLOGICAL SURVEY PROFESSIONAL PAPER 1538-R

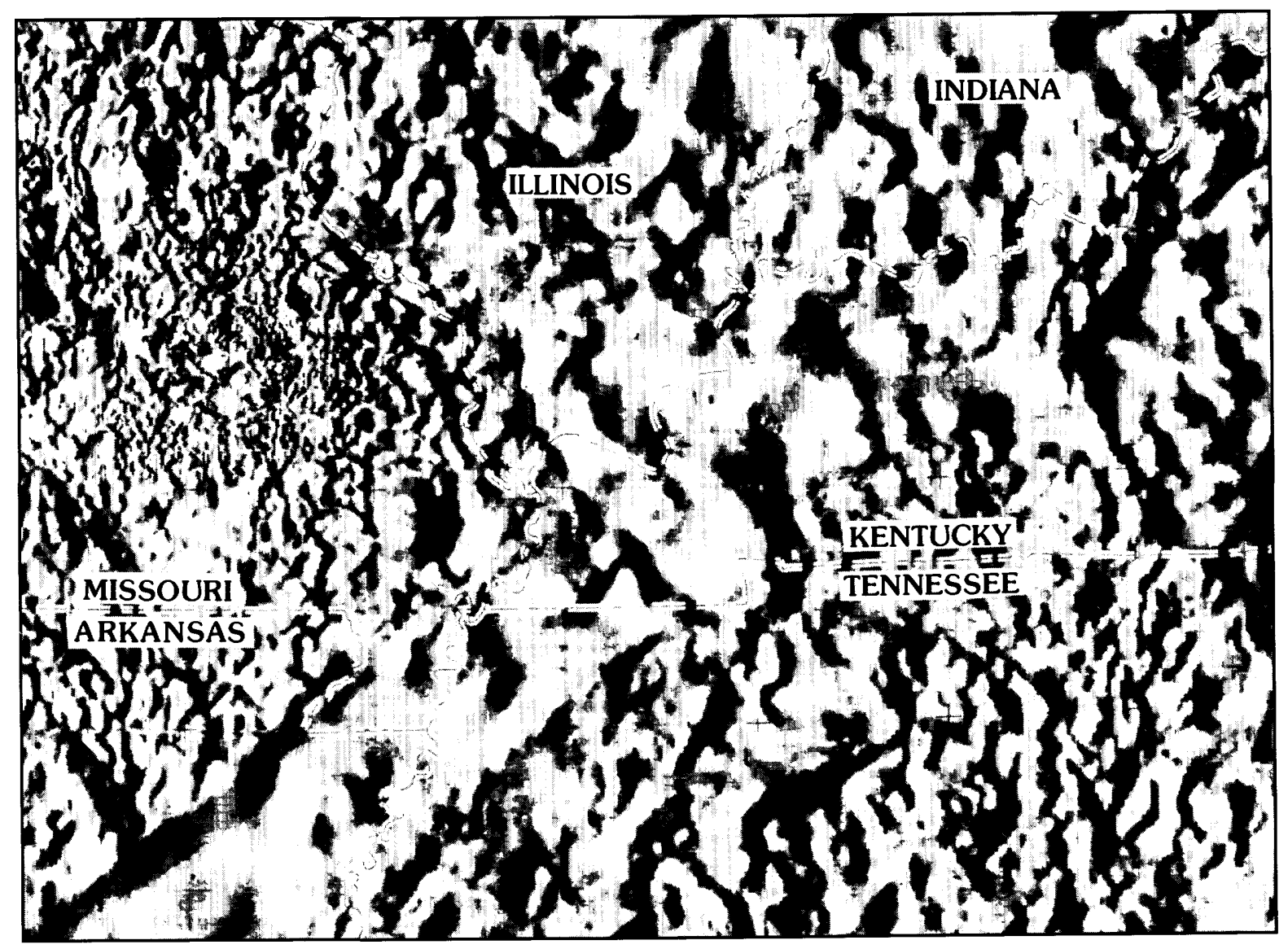


Cover. Gray, shaded-relief map of magnetic anomaly data. Map area includes parts of Missouri, Illinois, Indiana, Kentucky, Tennessee, and Arkansas. Illumination is from the west. Figure is from Geophysical setting of the Reelfoot rift and relations between rift structures and the New Madrid seismic zone, by Thomas G. Hildenbrand and John D. Hendricks (chapter $\mathrm{E}$ in this series). 


\section{Geomorphic Evidence of Deformation in the Northern Part of the New Madrid Seismic Zone}

By Karin Fischer Boyd and Stanley A. Schumm

INVESTIGATIONS OF THE NEW MADRID SEISMIC ZONE

Edited by Kaye M. Shedlock and Arch C. Johnston

U.S. GEOLOGICAL SURVEY PROFESSIONAL PAPER 1538-R

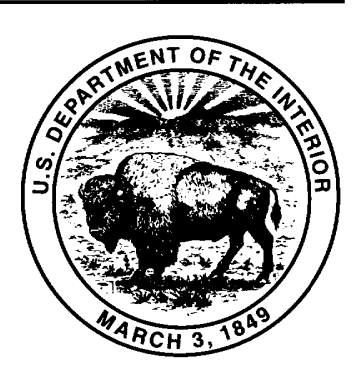

UNITED STATES GOVERNMENT PRINTING OFFICE, WASHINGTON : 1995 


\title{
U.S. DEPARTMENT OF THE INTERIOR BRUCE BABBITT, Secretary
}

\author{
U.S. GEOLOGICAL SURVEY
}

Gordon P. Eaton, Director

For Sale by U.S. Geological Survey, Map Distribution

Box 25286, MS 306, Federal Center

Denver, CO 80225

Any use of trade, product, or firm names in this publication is for descriptive purposes only and does not imply endorsement by the U.S. Government

Library of Congress Cataloging-in-Publication Data

Boyd, Karin Fischer.

Geomorphic evidence of deformation in the northern part of the New Madrid seismic zone / by Karin Fischer Boyd and Stanley A. Schumm.

p. $\quad \mathrm{cm}$.- (U.S. Geological Survey professional paper ; 1538-R)

(Investigations of the New Madrid seismic zone ; 1538-R)

Includes bibliographical references.

Supt. of Docs. no. ; I 19.16: P1538R

1. Geomorphology-Missouri-New Madrid Region. 2. Seismology-

Missouri-New Madrid Region. I. Schumm, Stanley Alfred, 1927-

II. Title. III. Series.

IV. Series: Investigations of the New Madrid seismic zone ; R.

QE535.2.U6159 1995 vol. R

[GB428.M8]

$551.2^{\prime} 2^{\prime} 09778895 \mathrm{~s}-\mathrm{dc} 20$

[551.4'1'09778985]

$94-43480$

CIP 


\section{CONTENTS}

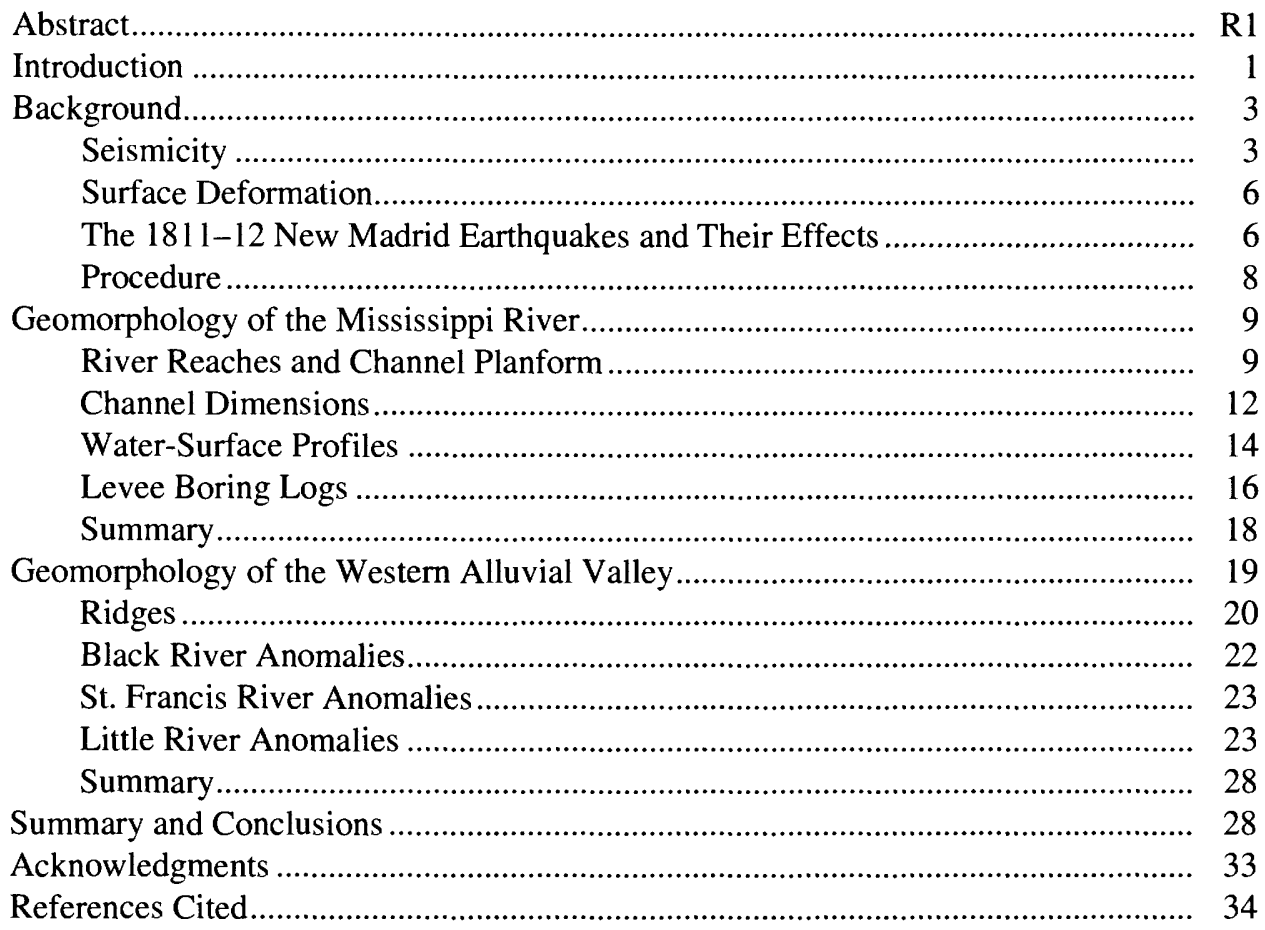

\section{FIGURES}

1. Index map of alluvial valley of Mississippi River between Cairo, Ill., and Helena, Ark.

2. Regional tectonic features of the New Madrid seismic zone showing plutons, the

Blytheville arch, the Pascola arch, the Bootheel lineament, and epicenters of microearthquakes in the upper Mississippi Embayment ..............................................................................

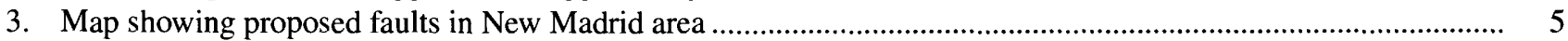

4. Map of New Madrid region showing geographic and geomorphic features including relationship of Mississippi River planform to the Lake County uplift ...........................................................................

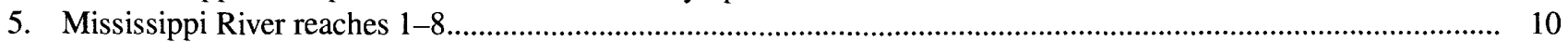

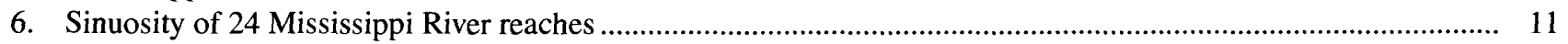

7. Projected-channel profile consisting of $\mathbf{1 8 8 0}$ bankfull-water-surface elevation plotted against valley miles ........... 11

8. Bankfull channel depth plotted against river mile for 1880 and 1903 surveys ................................................ 13

9. Bankfull channel width plotted against river mile for 1880 and 1903 surveys.................................................. 14

10. Channel width-to-depth ratio plotted against river mile for 1880 and 1903 surveys.......................................... 15

11. Bankfull and medium stages of Mississippi River showing Lake County uplift............................................ 16

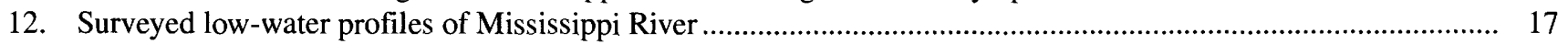

13. Slope of surveyed low-water profiles of Mississippi River ..................................................................... 18

14. Elevation of top of Tertiary sediments from borings on right bank and left bank in relation to 1962 and 1990 Mississippi River thalweg profiles ................................................................................. 19

15. Index map of northern part of Crowleys Ridge from Castor River to Jonesboro showing general drainage patterns and location of numbered topographic profiles............................................................... 20

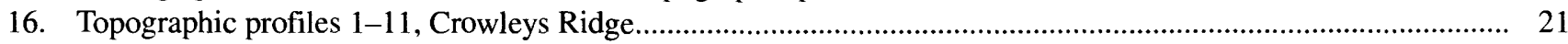

17. Map showing anomalous courses of Black and St. Francis Rivers................................................................... 22 


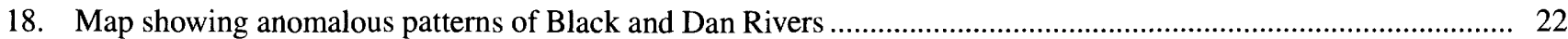

19. Map showing present course and old abandoned courses of St. Francis River ................................................. 23

20. Map showing course of Little River and meander belt width as mapped in the 1870 's .................................... 23

21. Location map showing drainage ditches, topographic anomalies, and braided-stream deposits in

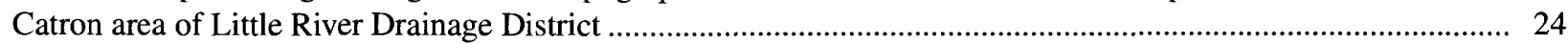

22. North-south surveyed profile of District 19, Ditch 1 North showing convexity in vicinity of Catron..................... 25

23. Surveyed profiles and linear best-fit lines of four north-south-trending ditches near Charter Oak and Canalou ...... 25

24. Topographic plot of northern Catron area, showing topographic depressions between Canalou and Charter Oak ... 26

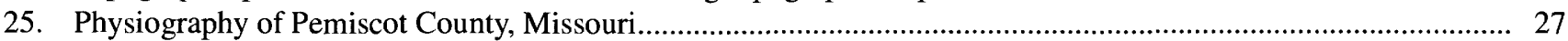

26. Location map of geomorphic features and available ditch surveys, Wardell-Pascola area .................................. 29

27. Topographic plot of Wardell-Pascola area showing geomorphic features and course of Little River..................... 30

28. Profile of Ditch 251 and constructed parallel profiles to east, showing regional convexity.................................... 30

29. Map showing previously identified structures and anomalous geomorphic conditions along Mississippi River ....... 31

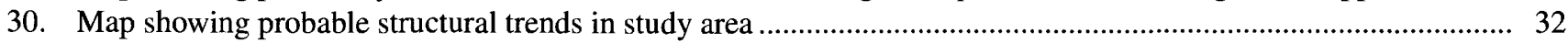




\title{
GEOMORPHIC EVIDENCE OF DEFORMATION IN THE NORTHERN PART OF THE NEW MADRID SEISMIC ZONE
}

\author{
By Karin Fischer Boyd ${ }^{1}$ and Stanley A. Schumm ${ }^{1}$
}

\begin{abstract}
In a geomorphic evaluation of the northern portion of the New Madrid seismic zone between Hickman, Ky., and Osceola, Ark., we have identified several locations where anomalous geomorphic conditions indicate possible surface deformation. For example, the slope, course, sinuosity, and dimensions of the Mississippi River have been affected by the Lake County uplift, and Tertiary-age sediments are exposed in its channel. Also, anomalous channel behavior near Caruthersville, Mo., and Barfield, Ark., suggests that these two reaches of the Mississippi River are structurally controlled. The Black River, northeast of Pocahontas, Ark., follows a peculiar angular course that suggests fracture control, and course changes of the Black, St. Francis, and Little Rivers may be tectonically controlled. The topography of Crowleys Ridge suggests that, between Jonesboro and Castor River, it is composed of at least three structural blocks that are bounded by northeast-trending faults.

By means of the geomorphic evaluation, we have identified anomalous surface features in the New Madrid seismic zone. Some can be directly linked to mapped structures in the region, whereas others may result from previously unidentified areas of surface deformation. The identification of these anomalies should provide direction for scientists who are employing subsurface techniques in order to locate tectonic deformation in the area.
\end{abstract}

\section{INTRODUCTION}

The New Madrid seismic zone is a region of great national concern due to the historic occurrence of severe earthquakes in the region. The identification of areas of active tectonism in the seismic zone primarily by geophysical techniques is ongoing. This study uses

\footnotetext{
${ }^{1}$ Ayres Associates, P.O. Box 270460, Fort Collins, CO 80527.
}

geomorphic techniques in an attempt to identify areas of possible surface deformation. Other geomorphic studies related to the New Madrid seismic zone include identification of deformed river features near New Madrid (Russ, 1982) and deformed terraces of streams in western Tennessee (Saucier, 1987).

The use of drainage patterns to identify geologic structures has been a common procedure utilized by geomorphologists and photogeologists. For example, a trellis pattern is characteristic of folded sedimentary rocks, and an angular pattern reflects joints or fault sets (Zernitz, 1932; Howard, 1967). More recently, variations of single-channel sinuosity patterns have been used to identify variations of valley slope that can be attributed to deformation (Schumm, 1986; Schumm and others, 1987, p. 251-278). Hence, it appears likely that areas of deformation in and near the New Madrid seismic zone can be identified using channel and drainage-pattern criteria. Therefore, the primary objectives of this investigation are: (1) to identify anomalous reaches of the Mississippi River between Hickman, Ky., and Osceola, Ark., by comparison of river pattern, dimensions, gradient, bed profiles, and water-surface profiles through time, (2) to identify anomalous channel patterns on the alluvial plain of the Mississippi Embayment, (3) to identify topographic anomalies along surveyed drainage ditches and channels on the alluvial plain, (4) to relate anomalous reaches of the Mississippi River, alluvial-plain channels, drainage networks, and drainage ditches to either known geologic structures, previously unidentified geologic structures, or other factors, and (5) to determine if structural controls have influenced the topography of high areas such as Crowleys Ridge and Sikeston Ridge.

The area investigated is that portion of the Mississippi Embayment between Hickman, Ky., and Osceola, Ark., that lies west of the Mississippi River and includes the Mississippi River itself. Therefore, this investigation will include portions of the Mississippi River and its meander belt, the northern part of the St. Francis Basin, Crowleys Ridge, and the Western Lowlands (fig. 1). With the exception of 


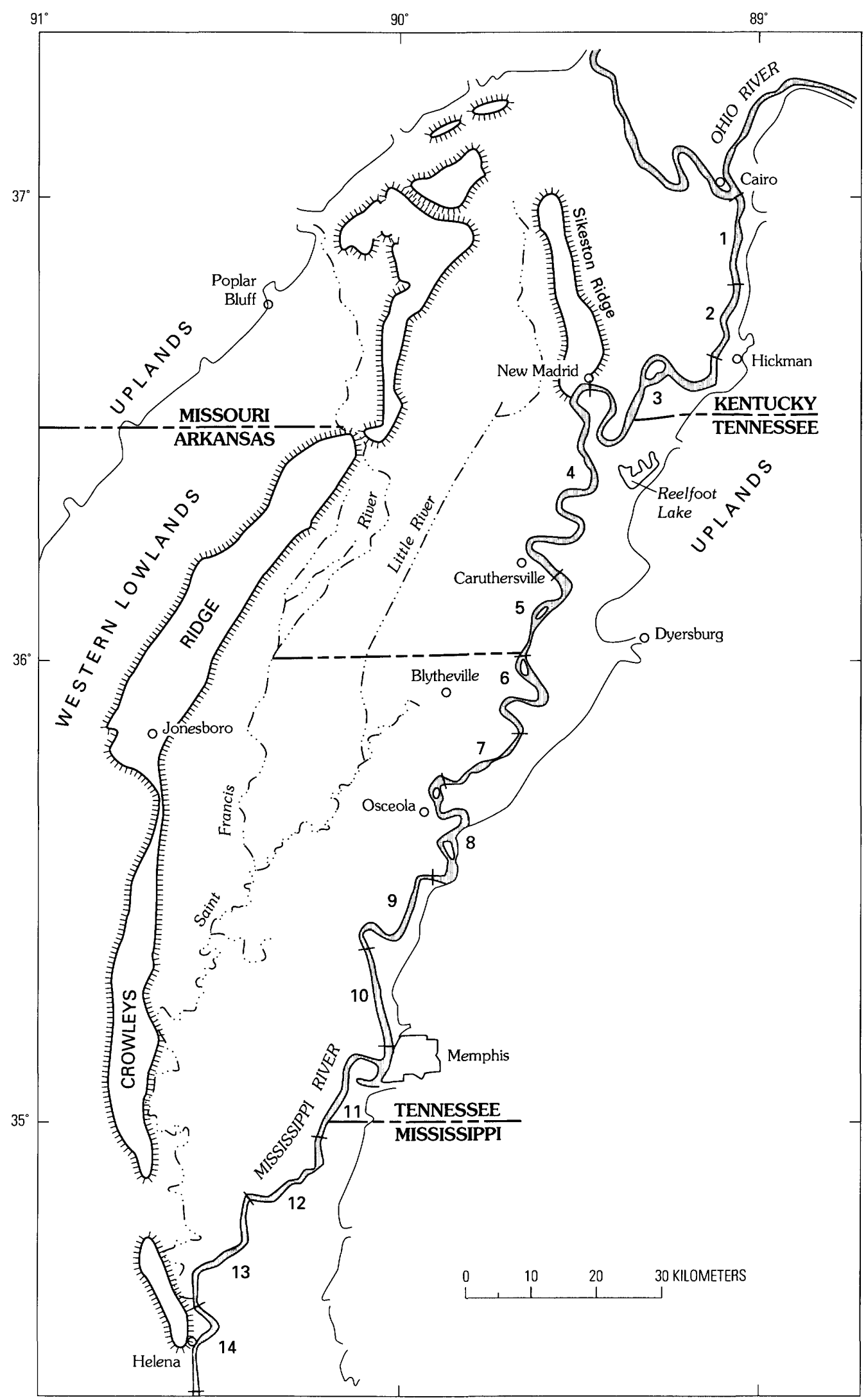

Figure 1. Index map of alluvial valley of Mississippi River between Cairo, Ill., and Helena, Ark. Numbers indicate Mississippi River reaches that have been identified between Cairo and Helena. Reaches 3-7 are discussed in this report. 
Crowleys Ridge and Sikeston Ridge, these areas are characterized by low relief and poor drainage, and, as a result, much of the area is drained by ditches.

\section{BACKGROUND}

The New Madrid seismic zone has been studied by numerous workers since the early 1970 's, and, although the information presented here is well known, it is important to describe the major structural features of the study area so that subsequent geomorphic analyses can be related to known structural trends.

The major subsurface feature in the region is the Reelfoot rift (fig. 2), a prominent southwest-trending graben that extends at least from New Madrid, Mo., to southwest of the Tennessee-Mississippi border. The northeastern end of the rift is poorly defined because it merges with the Rough Creek graben and other basement structures in southern Illinois. Aeromagnetic data indicate that the rift is approximately 70 $\mathrm{km}$ wide and more than $200 \mathrm{~km}$ long. Structural relief on the rift is about 1.6 to $2.6 \mathrm{~km}$ (Hildenbrand and others, 1982), and lower Paleozoic rocks are vertically offset about $1,000 \mathrm{~m}$ along the rift margins (Zoback and others, 1980).

The Pascola arch (fig. 2), a large, northwest-trending late Paleozoic and Mesozoic uplift, extends from the junction of the Ohio and Mississippi Rivers to northern Mississippi. Uplift began in late Paleozoic time and probably continued until Late Cretaceous time (McKeown, 1982). Schwalb (1982) shows the axis of the uplift crossing the Mississippi River in the central Missouri Bootheel. Recent studies (McKeown and others, 1990) show that the Pascola arch is part of a complex set of Paleozoic-age uplifts that are spatially associated with the Reelfoot rift.

McKeown and others (1990) conclude that a northeast-trending seismic belt is associated with the Blytheville arch, which follows the axis of the Reelfoot rift (fig. 2). They also indicate that the Blytheville and Pascola arches merge and that the resulting arch may be the result of diapirism that was initiated by tensional stress normal to the Reelfoot rift during the late Paleozoic. An isopach map of post-Tertiary alluvial deposits shows a marked thinning of alluvium of as much as $21 \mathrm{ft}$ along the trend of the Blytheville arch (Obermeier, 1989, plate 7). However, there are no obvious soil patterns (Ferguson and Gray, 1971; Brown, 1971) that reflect a topographic high corresponding to the arch. This is either because a surface expression of the arch does not exist or younger Mississippi River deposits have obscured it.

Numerous small faults have been mapped within the rift (fig. 3). The rift axis is associated with a zone of northeast-trending faults that parallel the rift trend. The Cottonwood Grove fault, with a vertical displacement of $80 \mathrm{~m}$, is one of several subparallel faults that follow this northeast trend (Zoback and others, 1980). O'Connell and others (1982) mapped the Ridgely fault, which is subparallel to the
Cottonwood Grove fault on the southeast side of a topographic high called Ridgely ridge. Ridgely ridge may reflect vertical offset on both the Cottonwood Grove and Ridgely faults (O'Connell, and others, 1982).

Because the Mississippi Embayment is presently under regional compressional stress and experiencing earthquakes, faults within the ancient Reelfoot rift are being activated (Zoback and others, 1980; Kolata and Nelson, 1991, p. 290; Heigold, 1991, p. 255). If the floor of the Reelfoot rift is at all comparable to the East African rift valley in Kenya, it is a very complexly faulted surface that could respond in different ways at different locations to stress (Walsh, 1966).

The U.S. Geological Survey has collected $240 \mathrm{~km}$ of high-resolution seismic reflection data from a boat in the Mississippi River through much of the New Madrid seismic zone (Crone and others, 1986). The seismic data for the river between river miles (RM) RM 850 and RM 839 are presented as three profiles that encompass the downstream limb of the Caruthersville Bend (fig. 3). The analysis of the data reveals many faults; however, none of the faults reach the surface. An obvious upwarp is present at about RM 842, on strike with the southwesterly projection of the Cottonwood Grove fault (fig. 3), which probably crossed the Mississippi River (Shedlock and Harding, 1982). The profiles indicate several faults with vertical offsets of 33 to $50 \mathrm{ft}$, which are associated with a broad arch with about $180 \mathrm{ft}$ of relief on the Cretaceous reflector. At the apex of the bend upstream of Caruthersville, where the flow is to the south, the seismic reflections show a broad, complex, channel-like trough with about $30 \mathrm{ft}$ of structural relief. It is in this area that subsidence occurred in 1811-12 (Penick, 1981, p. 39).

Hildenbrand and others $(1982,1992)$ utilized aeromagnetic data to delineate intrusive bodies in the region (fig. 2). The intrusions are located along rift-border and rift-axial faults, and they are thought to be composed of mafic rocks that were intruded hundreds of millions of years after the formation of the rift. The most recent period of intrusion was during Mesozoic time; no geophysical evidence exists that links the magmatic intrusions to surface deformation in the study area.

\section{SEISMICITY}

Seismicity trends in the New Madrid seismic zone delineate major fault trends and, locally, areas of surface deformation. Based upon the location of 741 earthquakes recorded between 1974 and 1978, Stauder (1982) defined the following pattern: (1) a major linear seismic trend about $120 \mathrm{~km}$ long extending northeastward from northeastern Arkansas past Caruthersville, Mo., (2) a seismic trend extending northeastward from just west of New Madrid, Mo., which is close to the western rift margin, and (3) between these two trends, a northwest trend of intense seismicity extending southeast from New Madrid, Mo. (fig. 2). This cross-rift seismic trend 


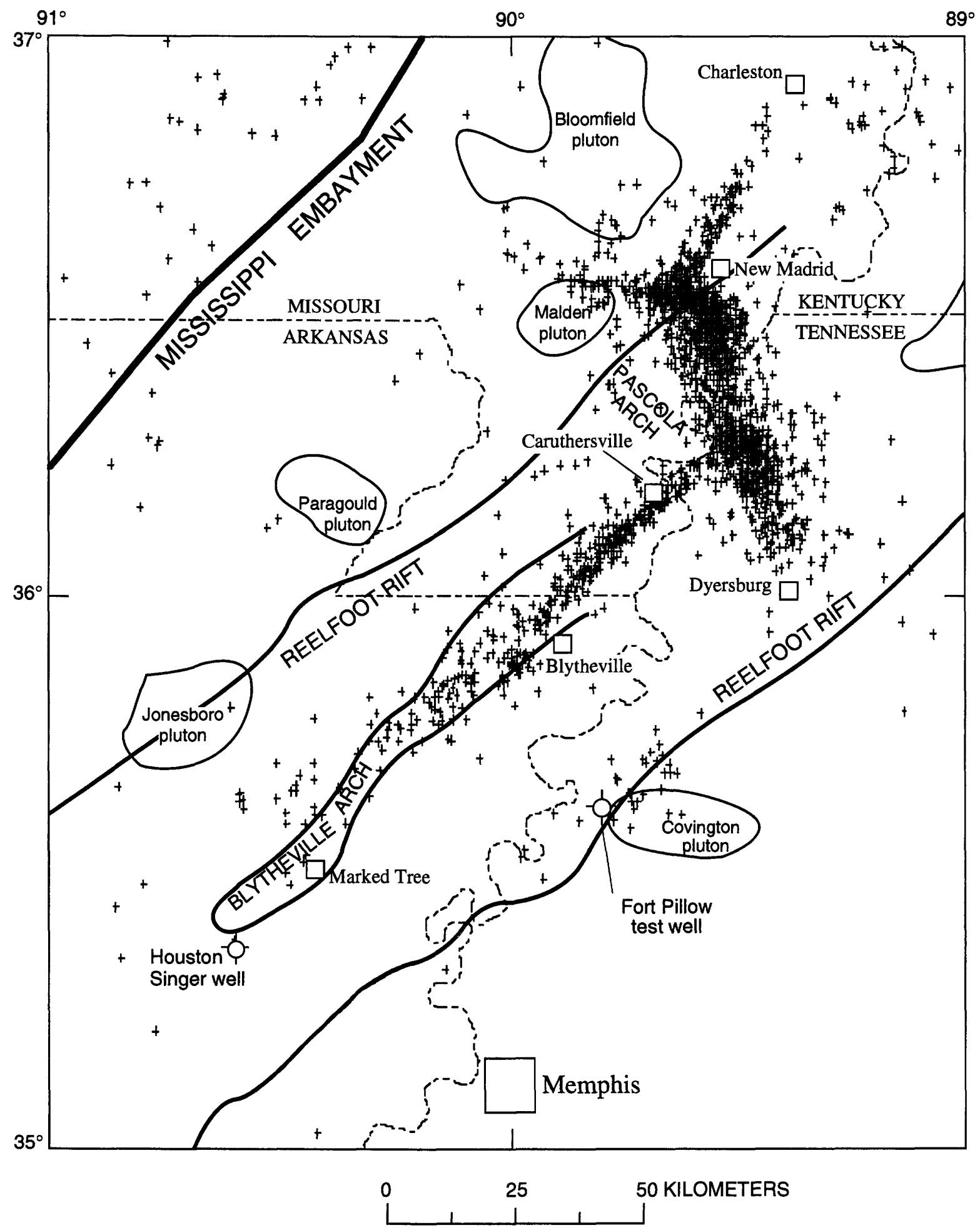

Figure 2. Regional tectonic features of the New Madrid seismic zone showing plutons, the Blytheville arch, the Pascola arch, the Bootheel lineament, and epicenters of microearthquakes (crosses) in the upper Mississippi Embayment (modified from Luzietti and others, 1992).

crosses the Mississippi River about 7 mi downstream of the town of New Madrid. Zoback (1979) mapped numerous vertical faults in this cross-rift trend. Chiu and others (1992) analyzed seismicity recorded by the PANDA array (portable array for numerical data acquisition) and found planar concentrations of earthquake hypocenters that suggest the presence of active faults in the seismic zone. The results indicate vertical strike-slip faults on the northeast-treading seismic 


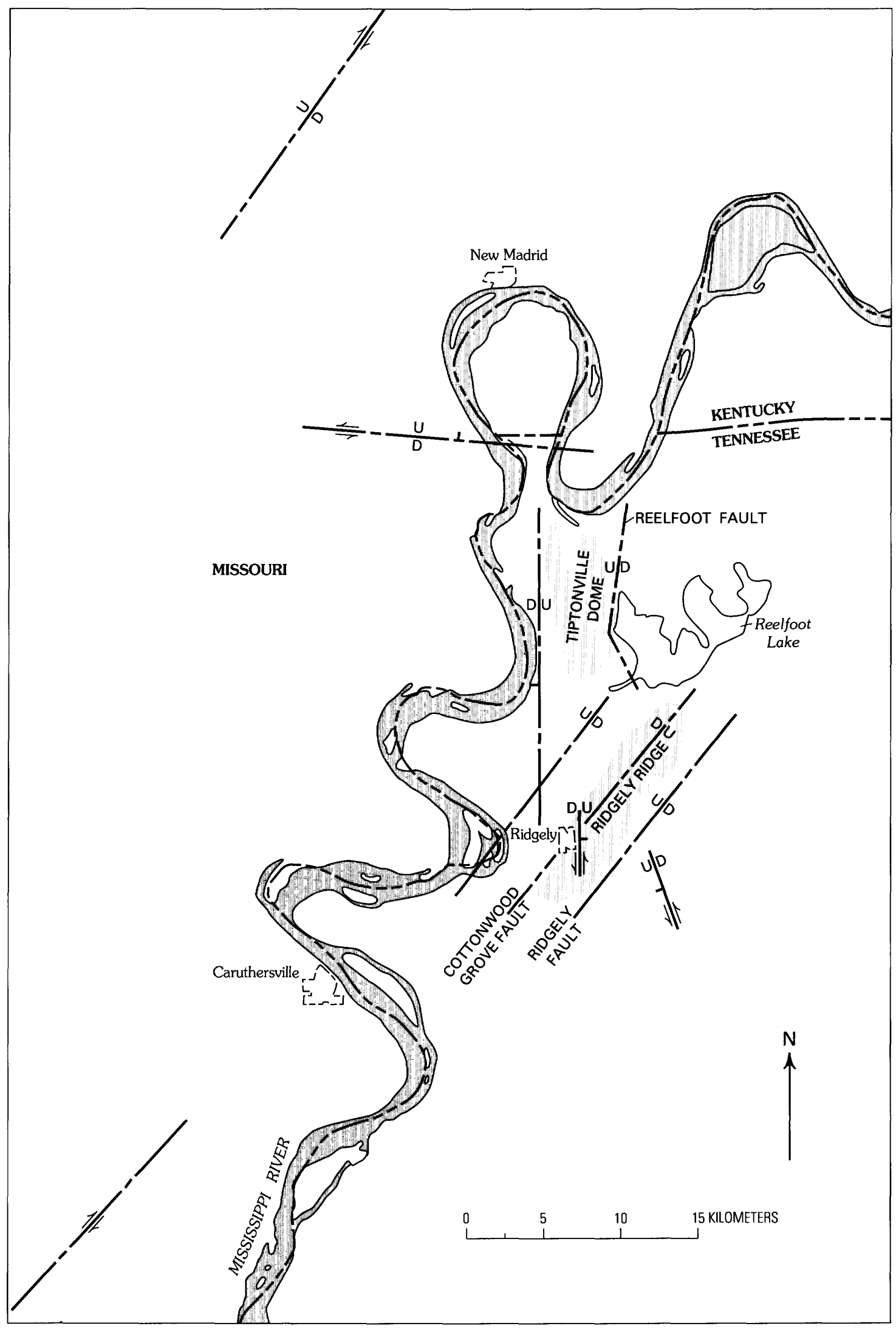

Figure 3. Map showing proposed faults in New Madrid area. Dashed lines represent faults U, upthrown side; D, downthrown side. Arrows indicate relative motion. A short dash perpendicular to the line indicates the direction of dip (from O'Connell and others, 1982). 
trends and a southwest-dipping fault plane on the cross-rift seismic trend. The distribution of seismicity in the New Madrid region indicates the presence of two northeast-trending fault zones that are separated by a northwest-southeast-trending cross-rift zone (fig. 2).

\section{SURFACE DEFORMATION}

An understanding of the location, extent, and cause of tectonic deformation of the modern land surface in the New Madrid seismic zone is helpful to subsequent analyses of the geomorphic response of the Mississippi River and its tributaries to such features. The most comprehensive study of surface deformation in the New Madrid seismic zone was conducted by Russ (1982).

The Lake County uplift is the most prominent surficial expression of modern deformation in the New Madrid seismic zone (fig. 4). Russ (1982) constructed topographic profiles of natural levees and abandoned channels of the Mississippi River, as well as profiles across the Reelfoot scarp, and demonstrated that the uplift is of tectonic origin. The uplift forms an elongate topographic high that rises as much as $30 \mathrm{ft}$ above the surrounding Mississippi River flood plain between Ridgely, Tenn., and just north of New Madrid, Mo., and it consists of two main centers, Tiptonville dome and Ridgely ridge (fig. 4).

Tiptonville dome is located near Tiptonville, Tenn., and it trends northwest-southeast. It is strongly asymmetric to the east, where its border coincides with the Reelfoot scarp (fig. 4). The most significant surface deformation associated with faulting in the area is the Reelfoot scarp. Structures identified in exploratory trenches that cross the Reelfoot scarp indicate that it represents a monoclinal flexure formed by uplift of the adjacent Tiptonville dome (Russ, 1982; Zoback, 1979; Kelson and others, 1992). These results are consistent with seismic reflection profiling, which display arched reflectors beneath the uplift (Hamilton and Zoback, 1982). Russ (1982) concluded that most of the deformation on the Tiptonville dome took place during the last 2,000 years. Furthermore, the uplift occurred primarily during at least three distinct earthquakes (two pre-1800, one during 1811-12). Kelson and others (1992) examined stratigraphic relations exposed in a trench across the Reelfoot scarp and, based upon radiocarbon dates of scarp-derived colluvial deposits, concluded that the penultimate event occurred between 1310 and 1540 A.D., and a possible earlier event occurred prior to about 900 A.D.

Ridgely ridge, located near Ridgely, Tenn., trends northeast-southwest (fig. 4). It is bounded on its eastern and western margins by subparallel faults that have been mapped by seismic reflection (fig. 3). Although the relatively subdued topographic nature of Ridgely ridge suggests that it is considerably older than the Tiptonville dome (Russ, 1982), Chiu and others (1992) concluded that faulting in this area is active.

The Mississippi River flows along the eastern margin of the Lake County uplift from Island 8 to Island 10, at which point it flows onto the uplift and turns north toward New Madrid (fig. 4). The river flows off of the uplift at approximately Island 13. Levee profiles have an anomalously low slope where the river flows along the uplift margin (Russ, 1982). Downstream of Island 11, both the flood-plain and levee profiles steepen sharply. Russ (1982) showed that a maximum of $2 \mathrm{~m}$ of uplift is recorded by the warped profiles. The post-1820 flood-plain profile steepens between Island 11 and Tiptonville. This steepening of the recent landform may reflect recent, or perhaps ongoing, flood-plain deformation in that reach (Russ, 1982).

Little data have been collected that document surface faulting in the region. The most significant surface deformation associated with faulting in the area is the Reelfoot scarp, which displays more than $3 \mathrm{~m}$ of offset in Holocene alluvium on the eastern margin of the Lake County uplift. However, Schweig, Shen, and others (1992) and Schweig, Marple, and Li (1992) have identified a major lineament extending 135 $\mathrm{km}$ from east of Marked Tree, Ark., to west of New Madrid, Mo. This feature, the Bootheel lineament, bisects the Missouri Bootheel and crosses both the northeast-trending seismic zone and the western margin of the Reelfoot rift (fig. 2). Although at some locations there is no topographic expression of the lineament, elsewhere it is a linear depression.

\section{THE 1811-12 NEW MADRID EARTHQUAKES AND THEIR EFFECTS}

Between December 16, 1811, and March 15, 1812, a total of 203 damaging earthquakes occurred in the New Madrid seismic zone. Between December 1811 and February 1812 , three earthquakes exceeded magnitude 8 . The three major shocks occurred on December 16, 1811, January 23, 1812, and February 7, 1812 (Fuller, 1912). Johnston (1982) estimated the magnitude of the first quake at 8.6. The damage from the first event extended over a radius of approximately $700 \mathrm{~km}$ from the epicenter. The epicenter of the first shock was probably located near Blytheville, Ark. (fig. 1) (Nuttli, 1982). A series of aftershocks, some damaging, followed the first event. The second major earthquake occurred on January 23, 1812. The magnitude of this event is estimated to be 8.4 (Johnston, 1982). The epicenter was probably located between Tiptonville, Tenn., and Portageville, Mo. (Nuttli, 1982, fig. 4). The last shock was the largest, occurring on February 7, 1812. Johnston (1982) assigned the earthquake a magnitude of 8.7. The epicentral location was near New Madrid, Mo., which was completely destroyed. 


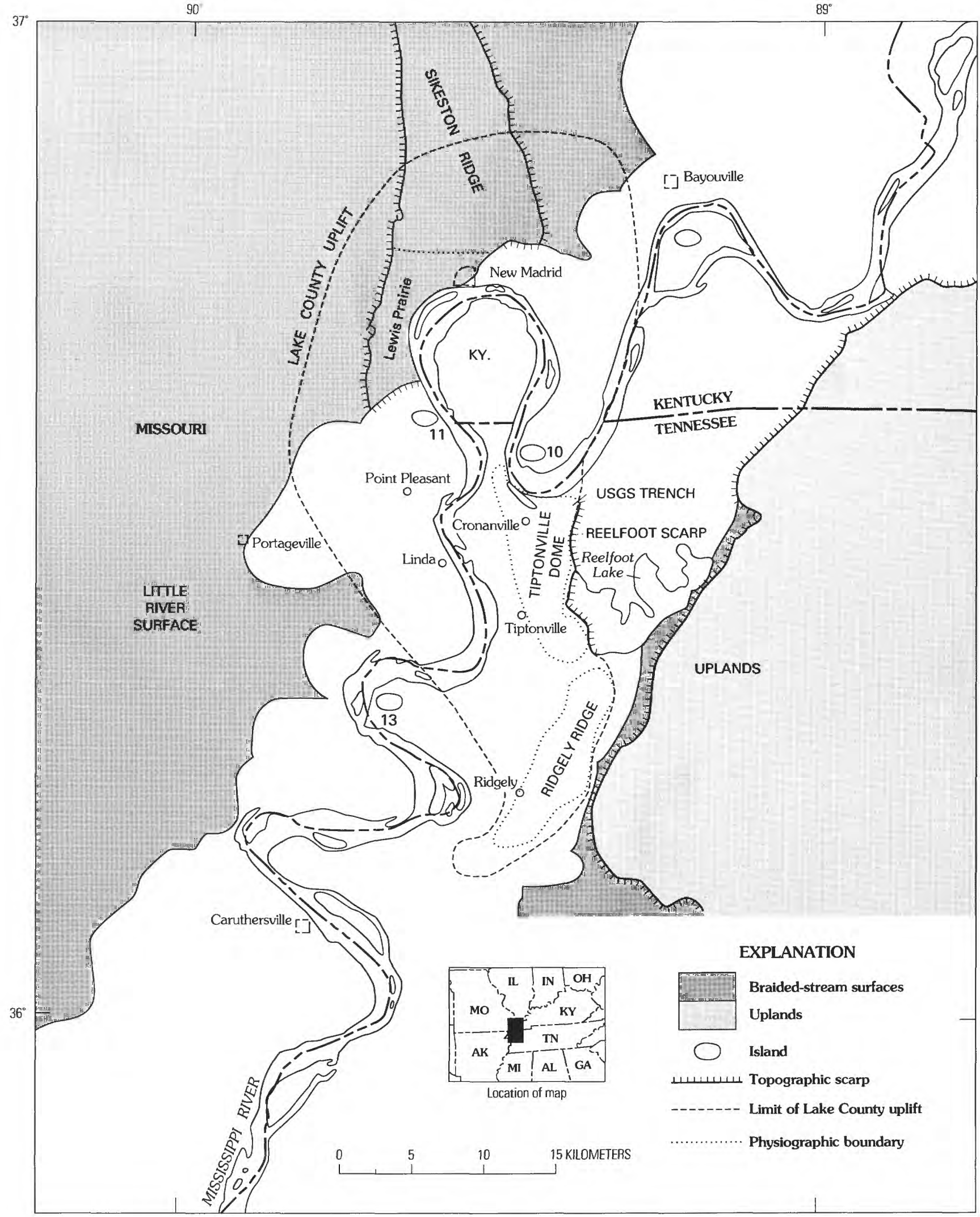

Figure 4. Map of New Madrid region showing geographic and geomorphic features including relationship of Mississippi River planform to the Lake County uplift (from Russ, 1982). 
The effects of the New Madrid earthquakes on the Mississippi River have been described by several eyewitnesses because boat traffic on the river was heavy during the winter of 1811-12. Summaries of these accounts are contained in published documents by Fuller (1912) and Penick (1981). For example, in a letter dated February 18, 1812, J. Smith described how the river had "wholly changed" between New Madrid and Memphis. In this reach, the development of bars and lodging of snags created severe hazards to navigation (Penick, 1981).

There is a recurring description of two distinct "rapids" in the Mississippi River near New Madrid. Penick (1981) concludes that they formed during the February 7, 1812, quake with its epicenter near New Madrid. Fuller (1912, p. 58) wrote, "Faulting, at least in the surficial deposits, was not a common nor a characteristic feature of the New Madrid earthquake, although it occurred at a number of points. Some of the faults crossed the Mississippi, causing rapids and even waterfalls." William Shaler, states that, a few miles above New Madrid, "he came to a most terrific fall, which, he thinks, was at least $6 \mathrm{ft}$ perpendicular, extending across the river... Another fall was formed about 8 miles below the town, similar to the one above, the roaring of which he could distinctly hear at New Madrid. He waited five days for the fall to wear away" (Fuller, 1912, p. 58). Approximately $7 \mathrm{mi}$ downstream of New Madrid, Russ (1982) demonstrated an oversteepening of the natural levee profile that indicates approximately $2 \mathrm{~m}(7 \mathrm{ft})$ of relative uplift.

Another consistently described effect of the earthquakes on the Mississippi River is extensive bank failure. Fuller (1912, p. 89) recorded the observations of the English naturalist Bradbury, who stated "immediately the perpendicular surfaces (banks) both above and below us, began to fall into the river in such vast masses as nearly to sink our boat by the swell they occasioned." Bank erosion was also described by Lloyd (Fuller, 1912, p. 89): "At times the waters of the Mississippi were seen to rise up like a wall in the middle of the stream and suddenly rolling back would beat against either bank with terrific force...during the various shocks the banks of the Mississippi caved in by whole acres at a time."

Eyewitness accounts of the event commonly include references to the river "running backward" during the first series of shocks. Penick (1981) attributed this phenomena to catastrophic bank failure and consequent generation of huge swells in the river. A rapid rise and fall of the river stage of between 1 and $4 \mathrm{~m}$ ( 3 and $14 \mathrm{ft}$ ) was described as well. Flow velocities of 5 to $8 \mathrm{mi} / \mathrm{h}$ ( 7 to $12 \mathrm{ft} / \mathrm{s}$ ) were reported to have accompanied this change in stage (Penick, 1981). Fuller (1912, p. 90) quotes a statement that describes the heaving of the bottom of the Mississippi as "sufficient to turn back the waters." "A bursting of the earth just below the village of New Madrid arrested the mighty stream in its course." Large whirlpools, or "sucks," were reported in the vicinity of New Madrid on February 7, 1812. These features were probably generated by sand blows in the bed of the river. As the bed was disturbed, tremendous numbers of trees that were buried by sand were dislodged and floated to the surface.

Numerous islands within the channel were reported to have sunk during the earthquakes. Fuller $(1912$, p. 10) writes of the December 16, 1811, earthquake in the following manner: "On the Mississippi, great waves were created, which overwhelmed many boats and washed others high upon the shore, the return current breaking off thousands of trees and carrying them out into the river. High banks caved and were precipitated into the river, sand bars and points of islands gave way, and whole islands disappeared."

Both uplift and relative subsidence occurred on the Mississippi River flood plain during the New Madrid earthquakes. Prior to the earthquakes, keelboats would access the Little River at Portageville, Mo. (fig. 4), from the Mississippi River through Portage Bayou. Passage through the bayou was impossible following the earthquakes due to extensive shallowing of the channel that was probably caused by massive bank failure or uplift on the western margin of the Lake County uplift. Russ (1982) suggested that this uplift may be associated with the development of a waterfall on the Mississippi River downstream of New Madrid.

One of the most striking effects of the 1811 and 1812 earthquakes was the blockage of Reelfoot Creek and formation of Reelfoot Lake. The lake is located just east of the Tiptonville dome and Reelfoot scarp in northwestern Tennessee, and it occupies several abandoned channels of the Mississippi River, which were probably oxbow lakes at the time of the earthquakes (Russ, 1982). The formation of the lake suggests that Tiptonville dome was uplifted, blocking Reelfoot Creek, or the area where the lake presently exists subsided or was compacted during the event. A detailed tree-ring analysis of bald cypress trees in Reelfoot Lake show a major increase of growth rate between 1812 and 1819, suggesting that the Reelfoot basin was inundated during the winter of 1811 and 1812 (VanArsdale and others, 1991; Stahle and others, 1992).

Reelfoot Lake is the most well-known of the "sunklands" of the lower Mississippi Valley. Several other sunklands are present on the west side of the river along the St. Francis and Little Rivers. Although, in recently published literature, there is a general consensus on the origin of Reelfoot Lake, there is no such agreement as to the origin of the sunklands to the west. Development of Big Lake on the Right Hand chute of the Little River has been attributed to alluvial drowning over 1,000 years ago (Saucier, 1970) as well as to the earthquakes of 1811 and 1812 (King, 1978; Guccione, and others, 1988).

\section{PROCEDURE}

The data in this report represent a compilation of existing geologic and topographic information obtained from 
various published and unpublished documents. Survey data, boring logs, channel and flood-plain cross sections, and dredge records, were obtained from the Memphis District Corps of Engineers. The Mississippi River Commission provided specific-gage plots, water-surface profiles, and historic channel-morphology data. River maps dated 1765 , 1820 to 1830,1881 to 1893 , and 1930 to 1932 , and hydrographic surveys for 1880 and 1915 were used in the study. Early maps of the area were obtained from the National Archives in Washington, D.C., and the Little River Drainage District office in Cape Girardeau, Mo. Field observations of the study reach include those made by the authors in September 1991, as well as during a river trip made by Schumm in 1989, when bed sediments were sampled. Flood-plain maps of the study area were obtained directly from the Federal Emergency Management Agency (FEMA). Surveyed profiles of drainage ditches were obtained from the Little River Drainage District in Cape Girardeau, Mo., under the guidance of Mr. Larry Dowdy, Chief Engineer.

Aspects of Mississippi River geomorphology that are evaluated in this study include bankfull channel width, depth, area; bed and water-surface profiles; and specific-gage plots. These data were provided by the Mississippi River Commission, Vicksburg, Miss. Morphologic data from 1821 and 1874 were retrieved from a report by Major Suter (1878). The 1821 data have been checked on original surveys and are found to be consistent. The 1874 survey was found to be less consistent, and it was not used in the analysis. The 1880 data are derived from a complete channel survey of the Memphis and Vicksburg Districts of the U.S. Army Corps of Engineers carried out in 1877-83. The source of the 1913-15 data are hydrographic-survey compilation books produced by the Vicksburg and Memphis Districts. The 1949 data were obtained from published maps of the hydrographic survey.

More recent surveys were obtained from the Mississippi River Commission. Morphometric data were derived from these surveys where possible, but these surveys do not extend to the top of the river bank, so calculation of the bankfull morphology is impossible. During 13 years after 1929 a program of meander cutoffs was undertaken in order to reduce flood peaks. As a result, 16 cutoffs reduced river length by $152 \mathrm{mi}$. The data that reflect post-cutoff program river conditions (post-1930) were only utilized for water-surface and thalweg profiles. Data on dredging and repeat surveys of benchmarks were obtained from the Memphis District, U.S. Army Corps of Engineers.

Maps of the Little River Drainage District prepared in 1924 that contain surveyed profiles of planned and existing drainage ditch routes were provided by the Little River Drainage District, and they were subsequently utilized to search for possible surface deformation on the Little River flood plain. These data were compiled into an $X, Y, Z$ database so that detailed topographic plots and profiles could be generated.
The geomorphic analysis consisted primarily of a compilation of existing data and a search for trends and anomalies on aerial photographs, topographic maps, and soil maps. The majority of data obtained from external sources were compiled and plotted by river mile or valley mile to determine lateral trends and anomalies. River miles (RM) are measured along the course of the river, which includes all of the meanders. Valley miles are measured in a straight line that parallels the course of the river. The geomorphic analysis of the Mississippi River is based primarily upon data provided by the U.S. Army Corps of Engineers in English units, which is the common usage for navigation and flood-control purposes, and these units of feet and miles have been used in this report. Additional field work, which would be required to determine if the anomalies identified using existing data were caused by surface deformation or other natural or human factors, was prevented by available time (1-year project) and funding.

\section{GEOMORPHOLOGY OF THE MISSISSIPPI RIVER}

Alluvial rivers, even great rivers such as the Mississippi, respond to hydrologic and geologic controls. Experimental studies have demonstrated that variations of valley gradient can significantly alter channel morphology (Schumm and others, 1987). For example, field investigations of the effect of active uplift on streams show that, as the stream approaches the axis of uplift, the valley-floor slope decreases, but once over the axis, the valley-floor slope steepens. In order to adjust to these slope changes, the river can alter its sinuosity. Hence, a moderately sinuous river will straighten on the reduced valley slope and become more sinuous on the steeper valley slope. In this way, the river attempts to maintain a constant gradient on a surface that changes slope (Schumm 1986; Schumm and others, 1987). Therefore, changes of river pattern can be the first clue that active or past tectonics has affected the area of pattern change. Of course, if more resistant rocks or coarser sediment appears in the channel on the crest of a structure, the river will also show the effects of these non-alluvial materials as it would to variations of flood-plain materials, such as clay plugs in cutoff meanders.

\section{RIVER REACHES AND CHANNEL PLANFORM}

Based upon the evaluation of early (pre-cutoff program) maps and profiles of the Mississippi River between Cairo, Ill. and Old River, La., Schumm and others (1994) divided the river into 24 reaches, of which 5, Reaches 3-7, are located within the area of this investigation (fig. 5A, 5B). 


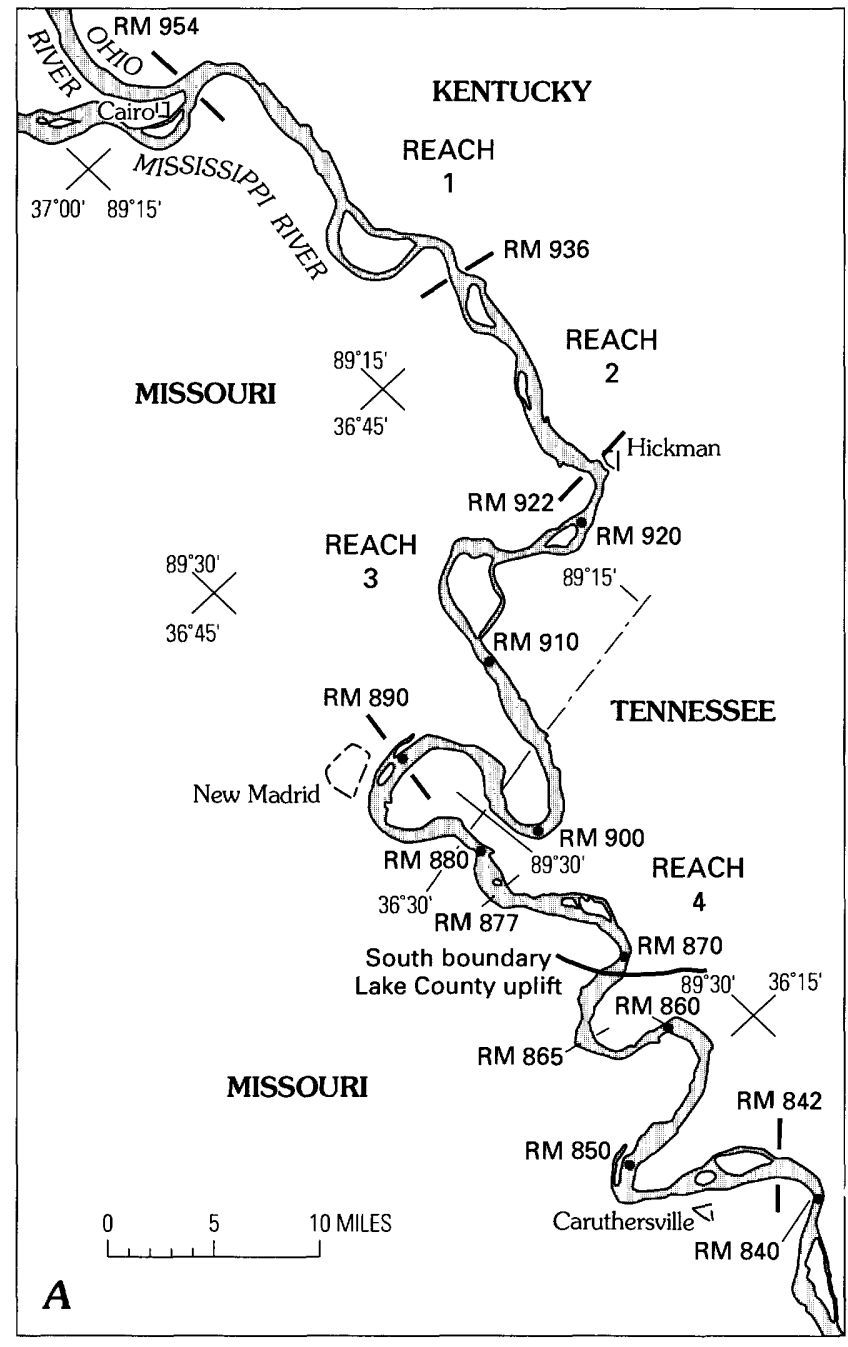

Figure 5 (above and facing column). Mississippi River reaches (from Schumm and others, 1994). RM, river mile (see text). A, Reaches 1-4. B, Reaches 5-8.

These reach descriptions and divisions are based upon pre-cutoff program (pre-1930) channel morphology. Individual reaches are characterized by different morphological characteristics and behavior, including channel-pattern differences, magnitude of pattern change through time (fig. 6), and changes of projected-channel slope, which in this case is the water-surface elevation plotted against valley distance (fig. 7).

Reach 3 extends from Hickman, Ky., to river mile (RM) 890, just upstream of New Madrid, Mo. (fig. 5A). Historically, this has been a sinuous and active reach, in which the river flows in a southwestward direction, away from the eastern bluff line of the valley. The Island 10 bend (RM 902 to 897) is cutting into the Tiptonville dome (fig. 4); the left bank is high as a result. The bend is presently revetted and is consequently unlikely to cut off in the near future. The New Madrid bend is effectively wedged between Tiptonville dome to the south and Sikeston Ridge to the north (fig. 4).

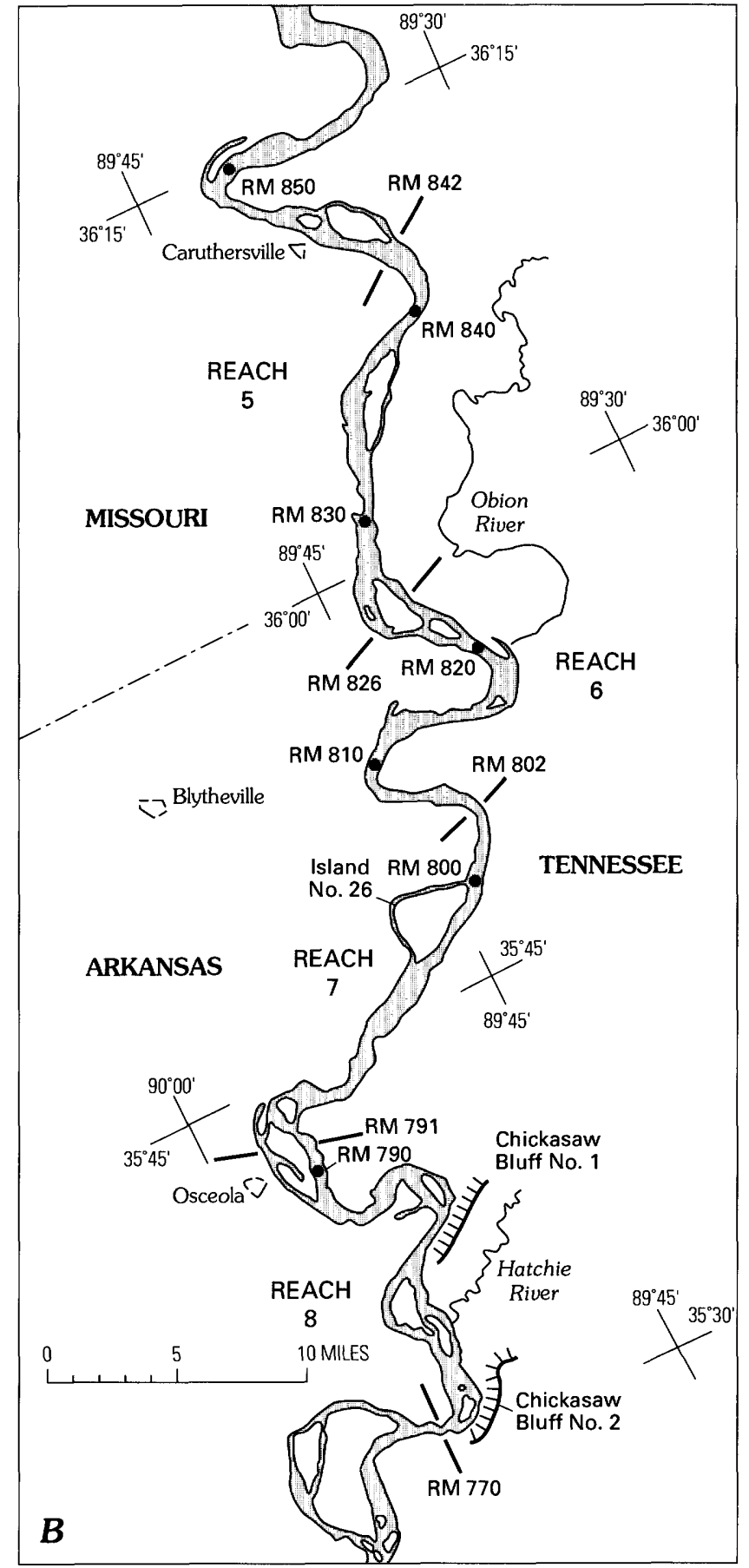

Sinuosity of the reach has been relatively high since 1765 , and it has been increasing (fig. 6). The projected-channel profile is relatively steep (fig. 7) as compared to upstream Reaches 1 and 2 .

Tertiary-age sediments are evidently exposed within the bed of Reach 3 under certain flow conditions; these units probably retard degradation. For example, clay was sampled from the bed of the channel near RM 919 in 1932, and, in 1989 , clay was sampled from the bed at RM 896.7, close to the location of a possible fault crossing (figs. 3 and $5 A$ ). A gravel dredge encountered "tight clay" at New Madrid. 


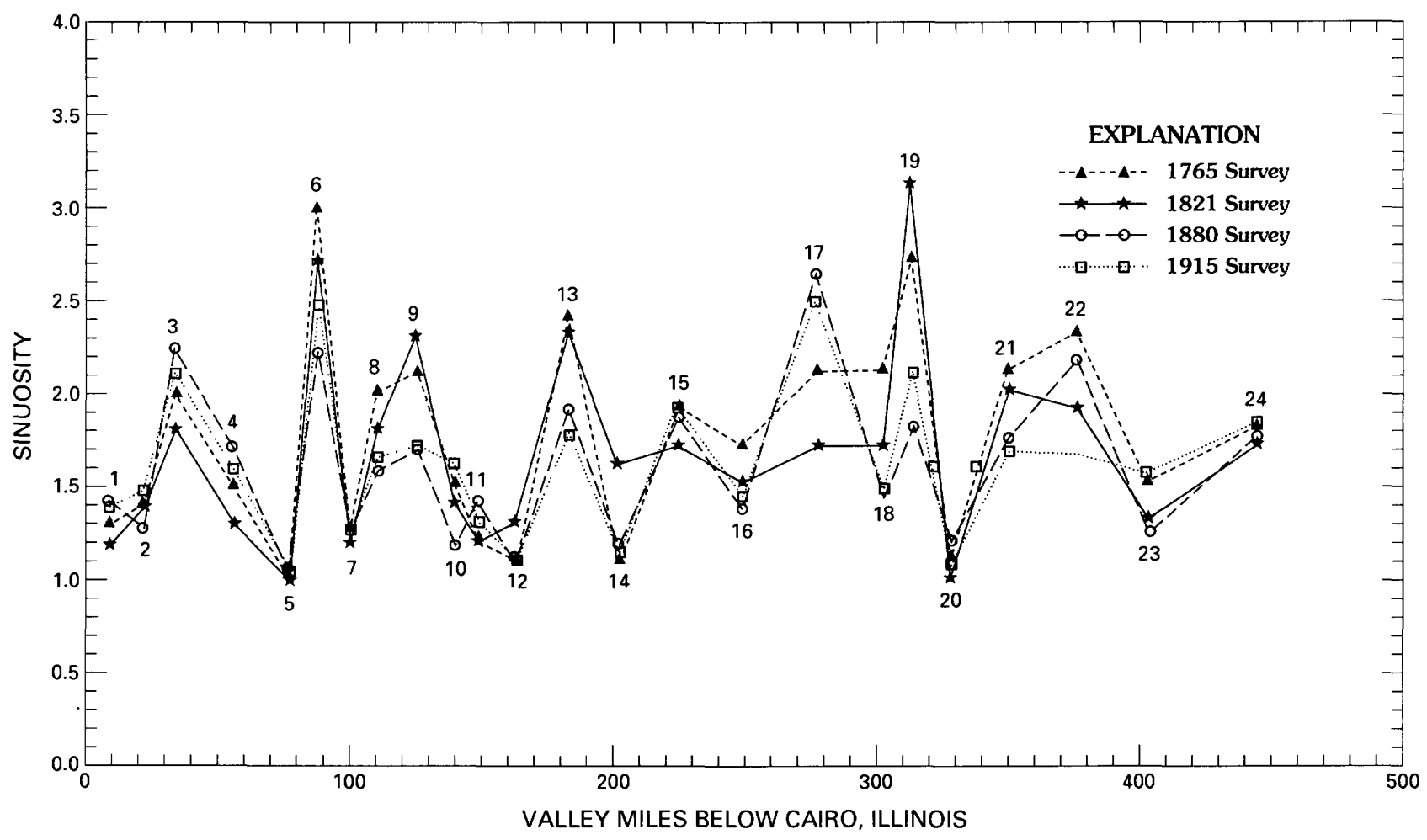

Figure 6. Sinuosity of 24 numbered Mississippi River reaches (from Schumm and others, 1994). Reaches 3 through 7 were included in this study. Sinuosity is defined as the ratio of channel length to valley length. When sinuosity equals 1 , the channel is straight. See text for definition of valley miles.

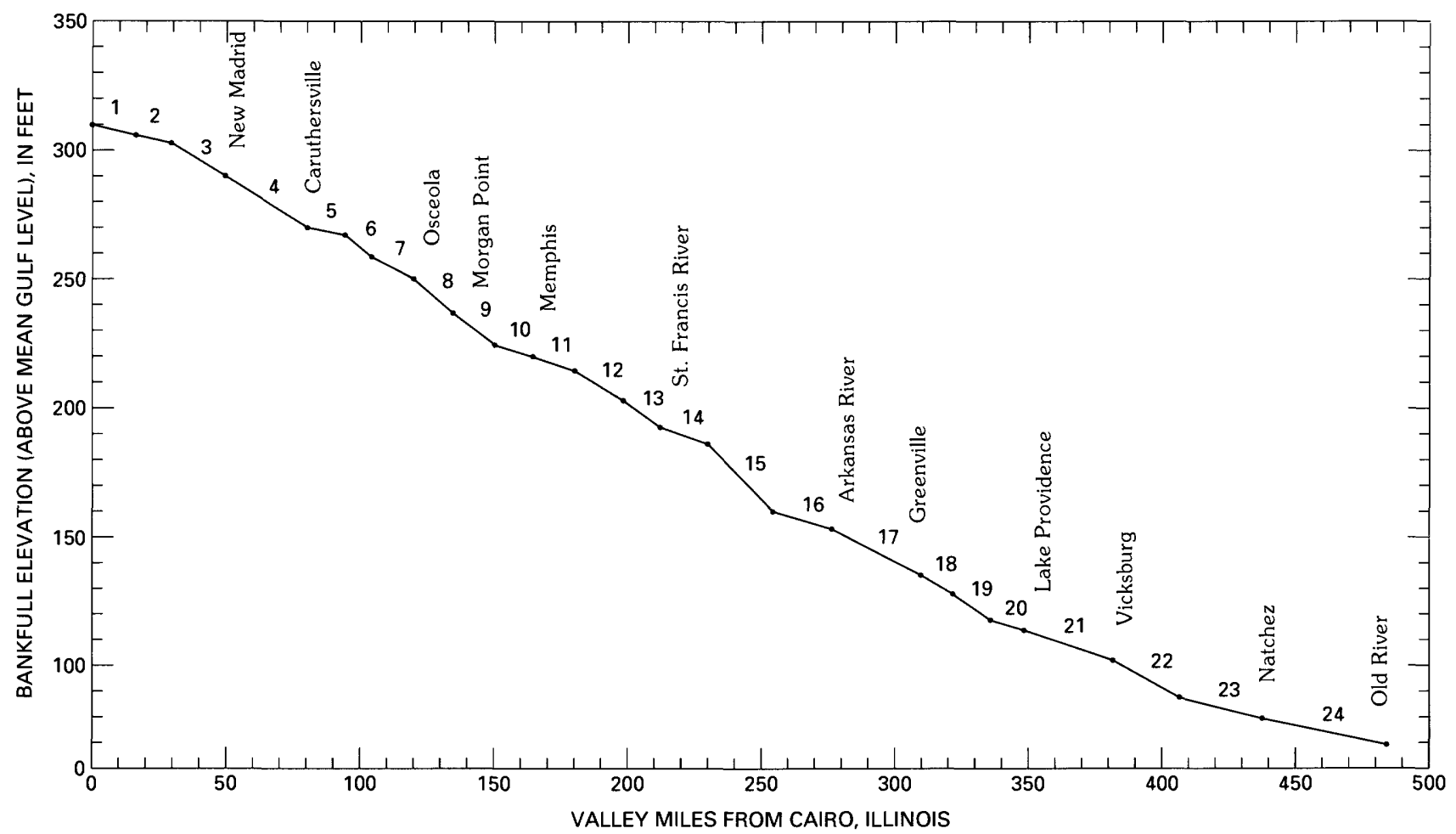

Figure 7. Projected-channel profile, consisting of 1880 bankfull-water-surface elevation plotted against valley miles (from Schumm and others, 1994). Reaches 3 through 7 (numbers on profile) were included in this study. See text for definition of valley miles. 
Reach 4 extends from New Madrid, Mo., to just downstream of Caruthersville, Mo. (fig. 5A). The projected-channel slope of Reach 4 is relatively steep, as a result of being located on the down-valley side of the Lake County uplift. It is striking, however, that Reaches 3 and 4 of the projected-channel profile do not depict the shape of the Lake County uplift because Russ (1982) showed a distinct upward convexity of the natural levees and flood plain. The convexity is not observed on figure 7 because the reach boundary at New Madrid coincides with a relatively low water-surface elevation on the margin of the Lake County uplift (see fig. 11). This reach has historically been actively meandering, and meanders increase in amplitude in a downstream direction. At the upstream end of this reach, near New Madrid, the river is eroding into Pleistocene-age alluvium of Sikeston Ridge. A fault has been mapped just downstream, at approximately RM 882 (O'Connell and others, 1982, fig. 3). Farther downstream, the Caruthersville bend appears compressed. That is, the downstream limb apparently is stable and fixed in position, or Caruthersville could not have persisted at its present location. This suggests that the bend is affected by a geologic control. The southwest-trending Cottonwood Grove and Ridgely faults may cross the river below Caruthersville, and Crone and Brockman (1982) suggest that the graben to the west of Ridgely ridge crosses the river at Caruthersville (fig. 3). A dredge operator reported that "large rocks" were being dredged at about RM 844, which may reflect exposure of Pleistocene-age gravels in the bed at that location.

Reach 5 extends from Caruthersville, Mo., to Island 21 at RM 826 (fig. $5 B$ ). It has remained remarkably straight through time (fig. 6). The projected-channel slope is relatively low (fig. 7). This reach may have been aggradational, as reflected by the presence of numerous islands and bars on the 1880 map (Schumm and others, 1994).

Reach 6 consists primarily of the Barfield bends (fig. $5 B$ ). The projected-channel slope is steep. Sinuosity has varied greatly through time (fig. 6). Heyl and McKeown (1978) suggest that a fault crosses the river just below the boundary between Reach 5 and Reach 6 . This may be the cause of the flatness of Reach 5 and the steepness of Reach 6 . Reach 7 extends from Island 25 to the downstream study limit at Osceola, Ark. (fig. 5B). This reach has been straight and stable. The projected-channel profile is relatively flat (fig. 7).

In summary, the pattern and slope of the Mississippi River between Hickman, Ky., and Osceola, Ark., is highly variable. The projected-channel slope data suggest that the river is affected by the Lake County uplift and perhaps by other faults and lithologic controls.

\section{CHANNEL DIMENSIONS}

The sinuosity and projected-channel profile reveal marked differences in Mississippi River reach characteristics (figs. 6 and 7), and it is logical to assume that similar variations in channel width, depth, and shape (width-depth ratio) occur. Abundant channel-dimension data exist because the Corps of Engineers hydrographic surveys include cross sections that are surveyed every one-fifth of a mile. In order to evaluate both spatial and temporal trends of Mississippi River channel morphology, cross-section dimensions (width, depth, and area) were retrieved from available survey documents, and the data were plotted against river mile. Channel-dimension data are presented in English units, which is the unit system utilized by the Corps of Engineers.

Bankfull channel depth approximates the elevation difference between the top of bank and the deepest point in the channel (thalweg) at a given river cross section (fig. 8). Between Hickman, Ky., and Osceola, Ark. (fig. 1), bankfull depth is quite variable, which probably reflects natural changes in bed elevation. However, between RM 870 and RM 900, the bankfull depth is generally low relative to the remainder of the study reach. This reach of river roughly coincides with the Lake County uplift, as delineated by Russ (1982), who identified convexities in natural-levee and flood-plain profiles over the uplift. His profiles suggest relatively recent deformation of the channel margin. The presence of relatively low bankfull depths directly over the uplift suggests that they are related to that deformation. If the depth reduction was caused by aggradation that caused pool infilling, the conveyance losses through the reach would make the area prone to flooding. The New Madrid County flood insurance rate map (Federal Emergency Management Agency, 1990) shows that the area is not especially flood prone, suggesting that the river has maintained overall flow conveyance over the uplift. Additional channel responses that would maintain conveyance with a reduction in channel depth include an increase of flow velocity over the structure or an increase of channel width. The hydraulic models of the Mississippi River obtained for this study did not contain sufficient detail to determine variations in average flow velocity over the structure. However, bankfull width appears to have increased (fig. 9).

Measurements of bankfull width approximate the maximum channel width within the bounding flood plain. Figure 9 shows a reach of anomalously large bankfull width between RM 870 and RM 900, which roughly coincides with the previously discussed reach of relatively low channel depth (fig. 8). This change in overall channel shape between RM 870 and RM 890 is apparent on the width-to-depth ratio plot (fig. 10). Thus, channel conveyance has been maintained over the uplift by channel widening. Within this reach, near RM 880, a fault has been postulated that crosses the river (fig. 3), and a "rapid" was described following the 1812 earthquakes (Penick, 1981). This fault, proposed by O'Connell and others (1982), has not been confirmed by any subsequent studies. A second reach of wide channel, located near Island 21 (RM 830), may be associated with a proposed fault (Heyl and McKeown, 1978) that crosses the river just 


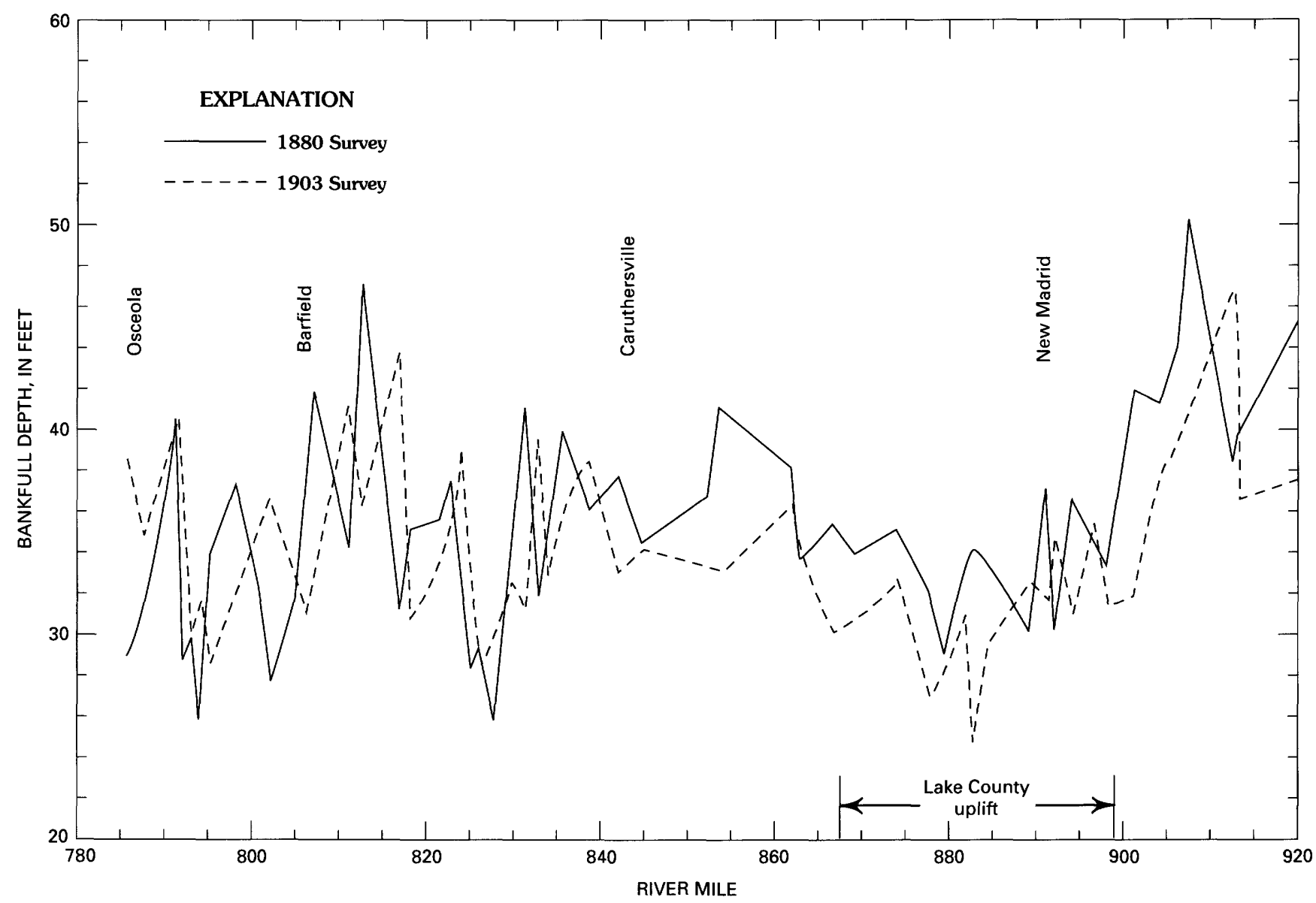

Figure 8. Bankfull channel depth plotted against river mile for 1880 and 1903 surveys. See text for definition of river mile.

below the boundary between Reach 5 and Reach 6 . A third wide reach between Osceola, Ark., and Barfield, Mo., is not related to any presently known structure.

O'Connell and others (1982) identified an east-west-trending fault that passes beneath the channel at approximately RM 882 , where an anomalously wide channel segment occurs. This fault, which was identified using limited subsurface seismic data, has not been demonstrated to extend to the ground surface, and subsequent studies have not confirmed the presence of a surface fault at this location. However, Chiu and others (1992) described a southwest-dipping thrust fault in the cross-rift seismic trend that passes beneath the river at this location. Although the fault is considered to be active, its point of emergence on the land surface is unknown. In 1812, eyewitnesses identified a "waterfall" in this same area, suggesting that there was vertical bed displacement. Fissuring and bank failure associated with the February 7, 1812, earthquake was probably intense at this location.

Destabilization of sandy bank strata by the seismic activity probably caused locally rapid channel migration at this location in 1812. This is supported by the presence of "sinks" in the vicinity of New Madrid, Mo. Fuller (1912) wrote "where the semifluid quicksand out-cropped in a near-by riverbank, as is the case at New Madrid, there is a possibility of undermining through the flowage of the quicksand toward the stream." Because this area of wide channel is located in the vicinity of one of the waterfalls described following the earthquake, it is also possible that the turbulence associated with bed offset may have resulted in extensive local bank failure and channel widening at the time of the earthquakes, which was followed by continued erosion due to the relative incompetence of the bank strata. Planform maps indicate that the area has been characterized by relatively rapid channel migration. The exposure of resistant sediments in the channel bed due to uplift at this location may also account for an anomalously wide and shallow channel; however, there are no known dredging accounts to support this assertion.

Although it is not possible to confirm a link between the 1811-12 earthquakes and channel morphology near New Madrid, Mo., the Mississippi River channel-dimension data indicate that locations of intense seismic activity during 1812 , as well as recent seismicity in the cross-rift seismic trend, are associated with reaches of anomalous channel morphology that are expressed by shallower depths and greater widths and width-to-depth ratios. 


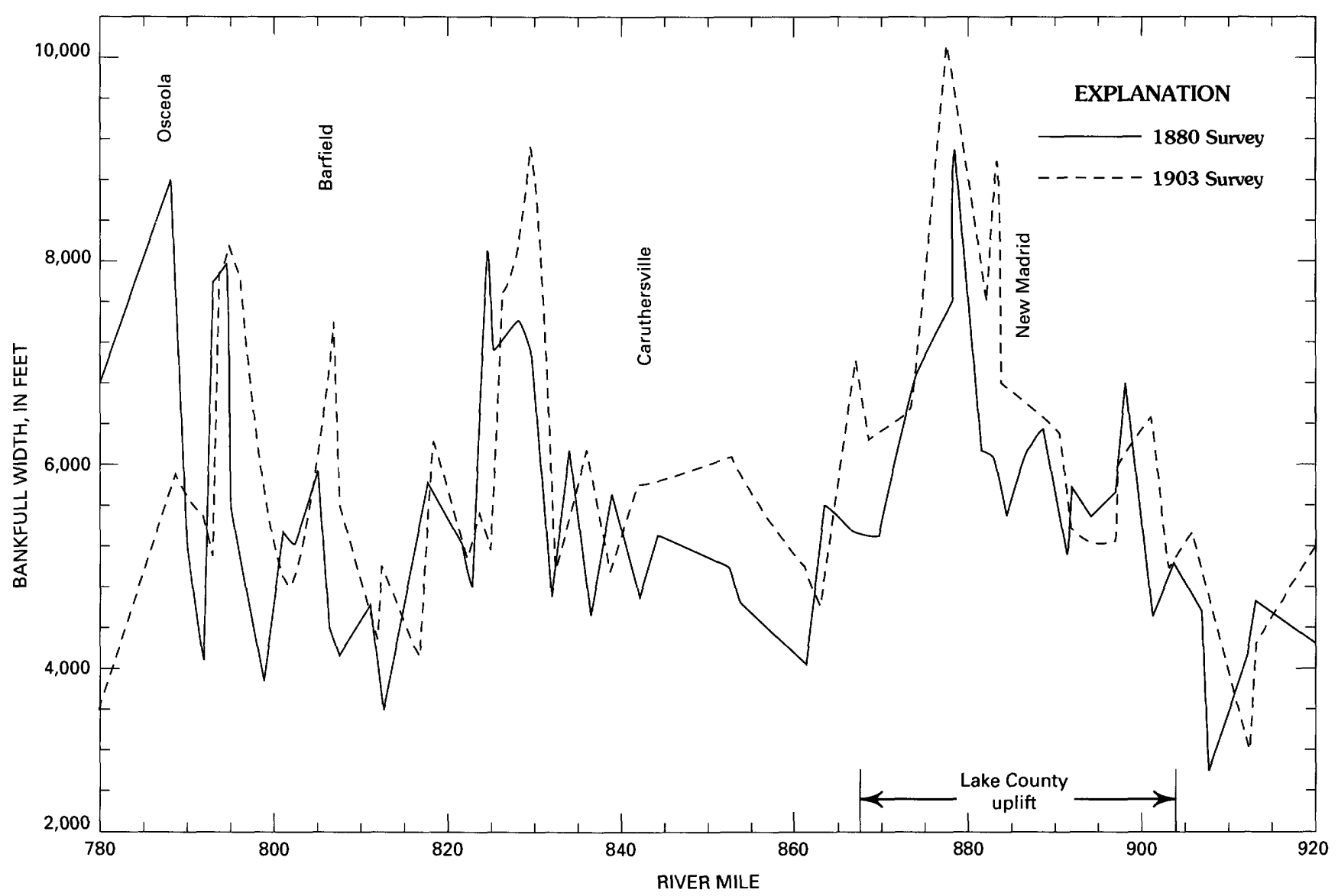

Figure 9. Bankfull channel width plotted against river mile for 1880 and 1903 surveys. See text for definition of river mile.

\section{WATER-SURFACE PROFILES}

The attempt to relate channel-bed profiles to structural elements on a large river such as the Mississippi can be extremely difficult due to large natural variations in pool and crossing elevations both spatially and through time. In contrast, water-surface profiles provide relatively smooth reference planes that broadly reflect both channel geometry and slope during a given time frame. However, water-surface profiles tend to obscure the effects of minor features in the channel bed and of channel geometry, and, therefore, they provide information only on larger scale features.

In order to maintain a database regarding low flow conditions for navigation purposes, the U.S. Army Corps of Engineers surveys the water surface every few years. Bankfull and medium stages were obtained from surveys dated 1880 and 1915 from Columbus, Ky., to Caruthersville, Mo. (fig. 11). The profiles show a distinct profile convexity at both bankfull and medium stage relative to linear best-fit lines in 1880 and 1915. This convexity extends from approximately RM 870 to RM 910, which coincides with the Lake County uplift. As noted previously, the projected-channel profile (fig. 7) does not show convexity over the Lake County uplift in Reaches 3 and 4 at bankfull flow conditions.
The bankfull water-surface profile of figure 11 explains the lack of a convexity on figure 7; the boundary between Reach 3 and Reach 4 is located at New Madrid, Mo., which is on the uplift margin and displays a relatively low bankfull water surface elevation (fig. 11). Consequently, bankfull water-surface elevations taken at Hickman, Ky., New Madrid, Mo., and Caruthersville, Mo., yield a relatively linear projected-channel profile over the uplift.

Surveyed low-water profiles for 1880, 1976, and 1988, which reflect average bed configuration, reveal that the more recent low-water profiles are below the 1880 profile, which suggests that the river has degraded (fig. 12). River degradation has occurred due to several factors, including the reduction of sediment loads by dam construction, the emplacement of dike fields, dredging, and the effects of downstream cutoffs; however, the profiles were all surveyed under different flow conditions, which are unknown. It is, therefore, impossible to quantify river degradation through time from these profiles.

The broad low water convexity between Hickman, Ky., (RM 920) and Caruthersville, Mo., which is present in the 1880 profile, is not present on the 1976 and 1988 profiles, which, in contrast, have a distinct stepped appearance (fig. 12). The steepest section of the recent water-surface profiles 


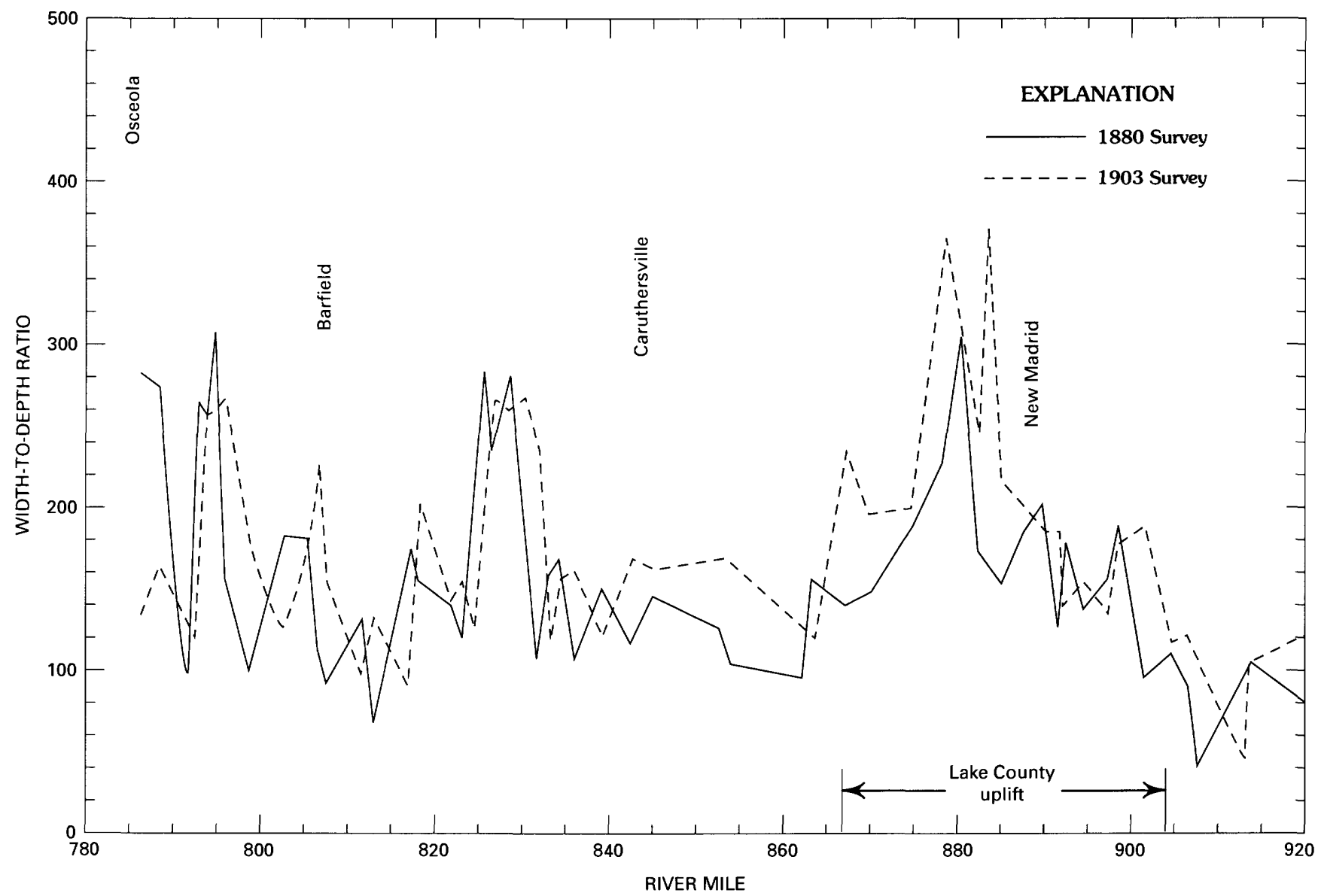

Figure 10. Channel width-to-depth ratio plotted against river mile for 1880 and 1903 surveys. See text for definition of river mile.

(1976 and 1988) is located just downstream of New Madrid, Mo., at about RM 888 (figs. 12 and 13). At this location, the 1988 profile shows a water-surface drop of approximately 4 $\mathrm{ft}$ over approximately $2 \mathrm{mi}$. This very steep water surface may reflect the exhumation of a fault scarp in the Mississippi River channel. The steep channel section is located approximately $5 \mathrm{mi}$ upstream of a fault mapped by O'Connell and others (1982) (fig. 3), where a waterfall formed following the February 7, 1812, earthquake according to eyewitness accounts (Johnston, 1982). It is also located in the vicinity of the active cross-rift thrust fault described by Chiu and others (1992).

Any vertical offset of the channel bed during the earthquake would have generated turbulence and bank erosion, but the fault scarp would have been eroded rapidly, and eyewitness accounts indicate that the rapids were short-lived. The eroded scarp probably persisted as an anomalously steep channel section that lengthened and flattened through time. Subsequent erosion of the bed would cause upstream migration of the steep channel section. Although the vertical exaggeration of figure 12 produces abrupt scarp-like features, the steep sections extend over several miles of channel.

The water-surface profiles and the historical accounts suggest that, during the 1812 event, vertical offset on the cross-rift trend resulted in uplift of the New Madrid bend on the northern portion of the Lake County uplift. This uplift produced convex water-surface profiles over the structure. Since the earthquake, the river has eroded its bed upstream from the original location of the fault (RM 883) to approximately RM 888, and, consequently, it has reduced the convexity. As the nickpoint continues to migrate upstream, bed erosion will continue. The most serious erosion will take place on the uplift itself. Upstream of the uplift, the net amount of erosion should decrease as incision crosses the crest of the uplift. It is unlikely that any degradation will occur upstream of RM 910 as a direct result of the tectonic activity in the region.

A second point of slight water-surface steepening near RM 870 (figs. 12 and 13) occurs where the Mississippi flows off of the Lake County uplift (Russ, 1982). No fault has been mapped at this location to date; however, the water-surface profiles suggest that the western margin of the Lake County uplift may be bound by a fault or monoclinal fold. A large clay plug intersects the channel at this location (the Tiptonville meander; Russ, 1982); therefore, the steep water surface may be due to resistant clay, which limits bed degradation and constitutes a local high in the channel at that location. It is also quite possible that Tertiary-age sediments 


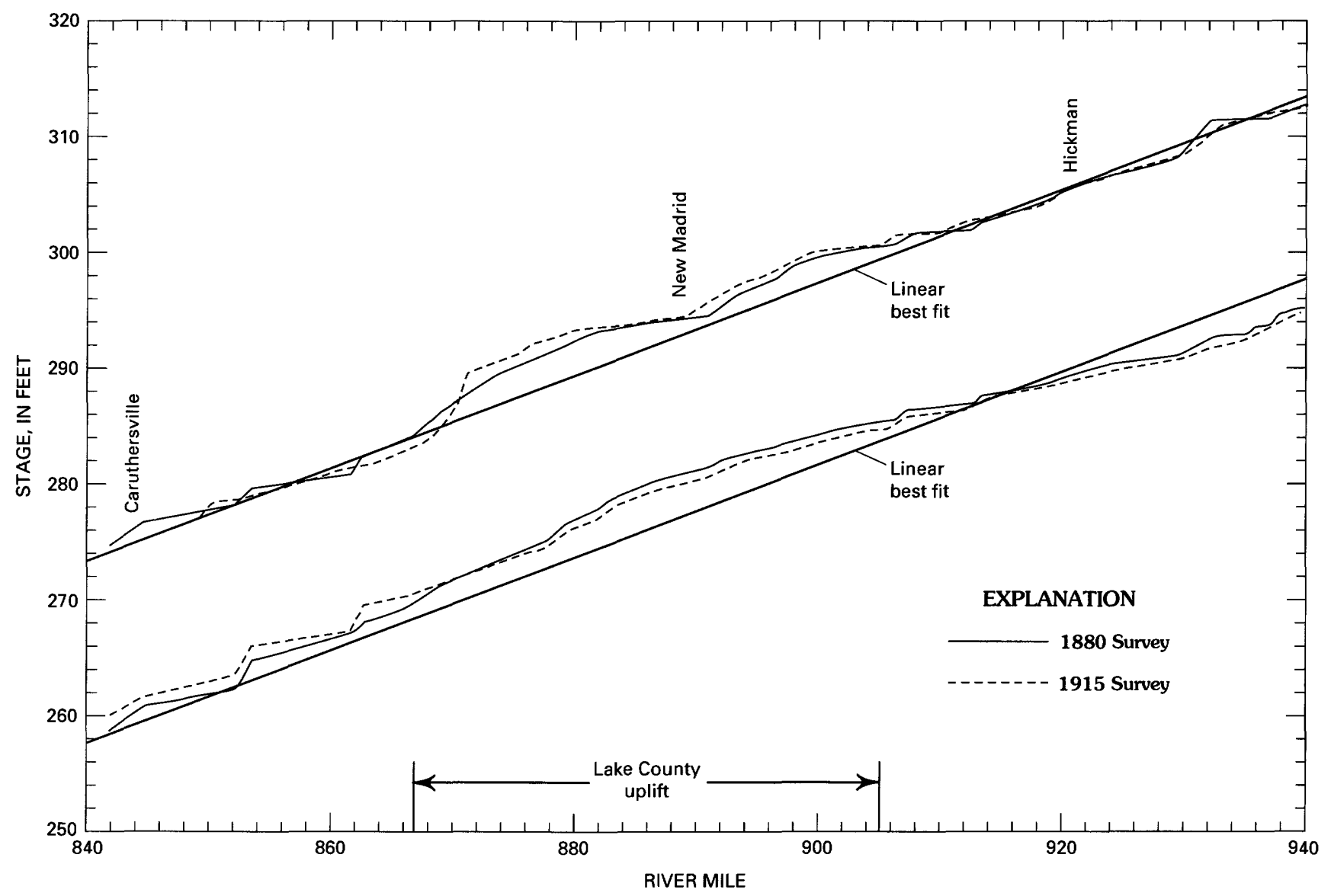

Figure 11. Bankfull and medium stages of Mississippi River and location of Lake County uplift as defined by Russ (1982). See text for definition of river mile.

are exposed in the channel at this location. Relatively high water-surface slopes at Caruthersville, Mo., (RM 848) are probably also the result of lithologic controls by a clay plug and possibly by the presence of Tertiary-age sediments. Other localities of steep water-surface slopes include RM 820 , on the upstream end of the Barfield bends, and at RM 79 , near Osceola.

In summary, the water-surface profiles suggest that the river is responding to 1811-12 uplift at the New Madrid bend by eroding its bed over the uplift. Bankfull channel morphology reflects the pattern of the entire Lake County uplift, but low-flow morphology appears to be more affected by local structures. Steep low-water profiles are due either to fault rupture of the channel bed or lithologic controls. Where lithologic controls are Tertiary-age sediments, they may reflect underlying structures, such as at Caruthersville, Mo., where the axes of the Pascola arch and the Cottonwood Grove fault cross the river.

\section{LEVEE BORING LOGS}

To evaluate the potential for bedrock controls on channel morphology within the study reach, levee boring logs were obtained from the Memphis District, Corps of Engineers. The boring logs were of holes drilled to the contact between the base of Quaternary alluvium and the top of Tertiary-age sediments. This contact marks a dramatic change because the Tertiary units are partially lithified and dense, as compared to the relatively unconsolidated overlying alluvial deposits. These Tertiary-age units are consequently capable of affecting the river where they intersect the channel because they are more difficult to erode.

At most locations, the upper surface of Tertiary-age sediments is located well below the thalweg elevation of the Mississippi River, although there are a few notable exceptions (fig. 14). Downstream of Caruthersville, Mo., the Tertiary units are generally well below the bed of the 


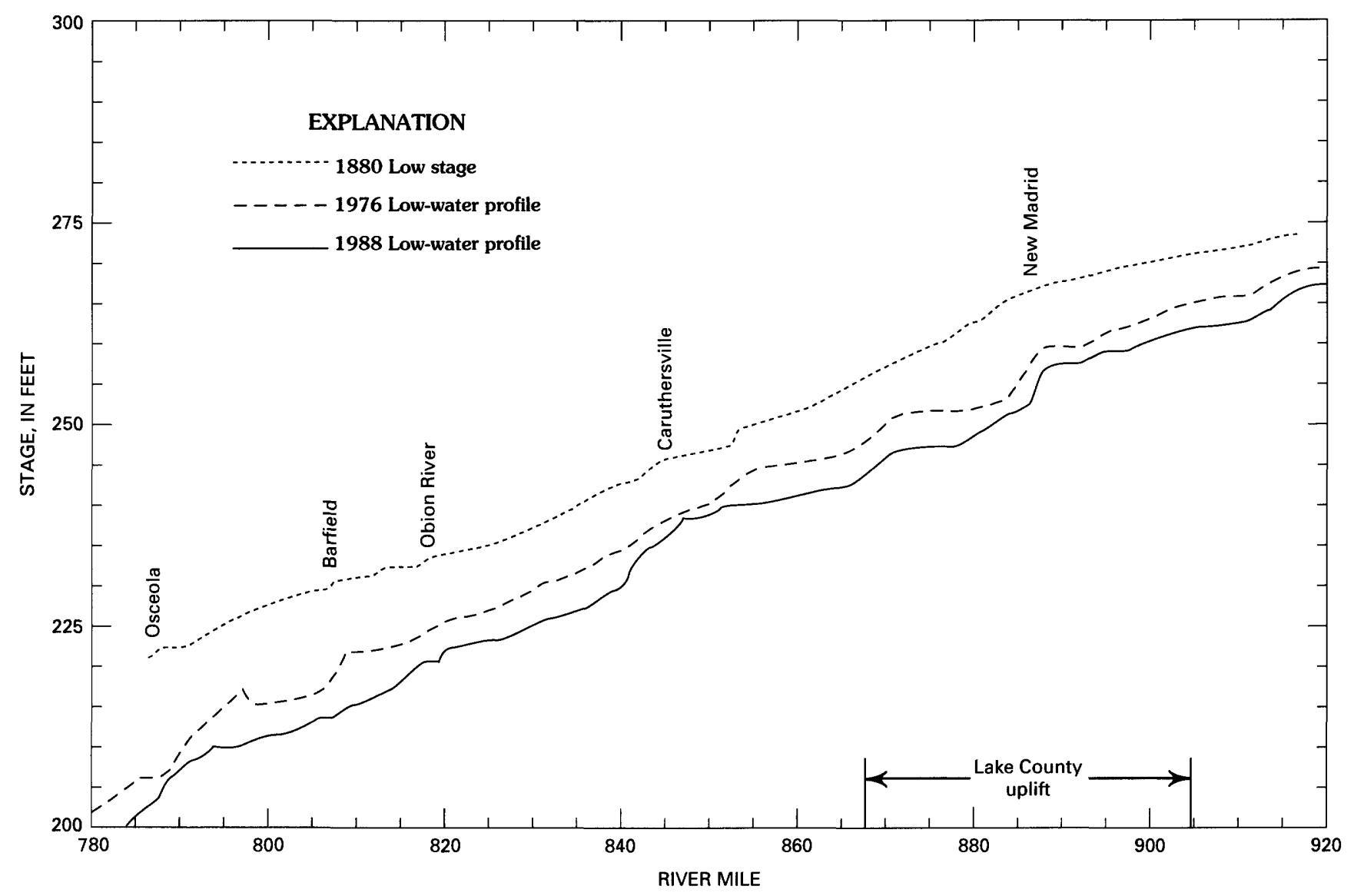

Figure 12. Surveyed low-water profiles of Mississippi River. See text for definition of river mile.

channel. Near Caruthersville and Hickman, Ky., the Tertiary units are very close to, and probably intersect, the channel bed. Because the borings were obtained for levee seepage studies, they do not represent mid-channel conditions; at best, they are located at topbank, but commonly the levees are set back from the channel and so are the borings. Therefore, the river-bed profile and the boring sites are offset. Where the levee closely borders the channel, the information is the most reliable - the elevation of the top of the Tertiary units may vary by as much as $12 \mathrm{ft} / \mathrm{mi}$.

One such case where the levee closely borders the channel is on the right (west) bank at Caruthersville, Mo. Just upstream of Caruthersville at RM 849, Tertiary units appear to have been exposed in the bed of the channel in 1962 (fig. 14). This bend has remained extremely stable through time relative to the rest of the study reach; it is likely that the presence of a clay plug in the channel bank and Tertiary rocks in the channel bed have limited rates of lateral adjustment of the channel at this location. The exposure of Tertiary units in the bed of the Mississippi River near Caruthersville occurs on the crest of the Pascola arch, which trends northwest near Caruthersville (fig. 2). The correspondence between the relatively shallow Tertiary units and the axis of the Pascola arch implies that the structure was active during Quaternary time. No structural evidence has been documented to indicate Tertiary deformation of the Pascola arch. Caruthersville also lies on the western margin of the Blytheville arch and the northeast-trending axial seismic trend (fig. 2).

Few borings were available between Caruthersville and New Madrid, Mo. (fig. 14). Where available, however, the top of the Tertiary sediments is relatively close to the channel bed. A distinct high is present on the Tertiary surface near RM 870. This reach is characterized by an anomalously steep section in the water surface profiles (figs. 12 and 13), where the river flows off of the Lake County uplift. This location marks the approximate intersection between the 


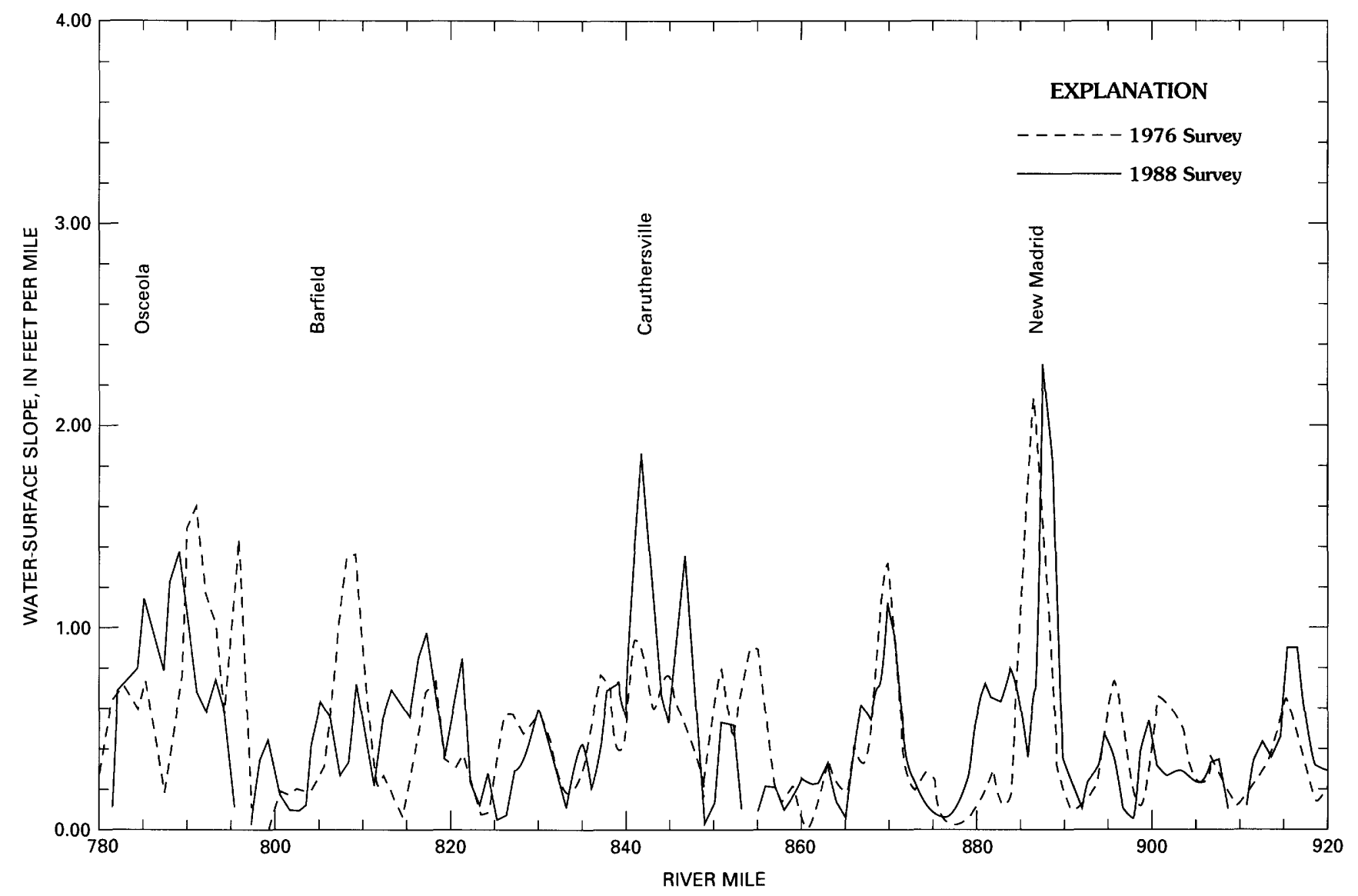

Figure 13. Slope of surveyed low-water profiles of Mississippi River. See text for definition of river mile.

northeast-trending axial seismic trend and the northwesttrending cross-rift seismic trend (fig. 2). With the available data, it is impossible to pinpoint exact locations of Tertiary sediments in the river; it is likely, however, that they provide some element of vertical control to the bed around RM 870 .

A third location of possible geologic control by Tertiary units is near Hickman, Ky. (fig. 14). At this location, the top of the Tertiary slopes from right bank to left bank (approximately north-south). This may affect the river planform in the Hickman area, and the southward migration of the river near Hickman toward the bluff line may be in part due to the local configuration of the Tertiary erosional surface. In addition, water-surface profiles upstream of Hickman have remained relatively constant through time; this consistency may be related to vertical stabilization of the bed by exposure of relatively resistant Tertiary units during high flows, when the bed is generally scoured.

\section{SUMMARY}

Locations within the Mississippi River study reach that display anomalous geomorphic features should be considered as potentially affected by tectonism. The first and most prominent of these locations is the New Madrid bend. Within this reach, the river flows over the Lake County uplift. The downstream limb of the New Madrid bend near RM 880 is anomalously wide and shallow and has migrated eastward at a relatively rapid rate. Eyewitnesses described a rapid near RM 880 in 1812 (Johnston, 1982); other researchers have mapped an active east-west-trending fault beneath the river in this vicinity based on seismic data (O'Connell and others, 1982; Chiu and others, 1992), although the surface location of any such fault has not been decisively determined. The anomalous channel behavior in this reach may be related to displacement of the channel bed during the 1812 event. A steep water-surface profile a few miles upstream may reflect the upstream migration of the nick point following bed displacement (fig. 12). The upper contact of the more resistant Tertiary-age units is relatively close to the channel bed in this area, and this may play a role in controlling channel dynamics in the reach (fig. 14). Farther downstream, near RM 870 on the downstream margin of the Lake County uplift, additional faulting or folding is suggested by a steep low-water profile (figs. 12 and 13).

The Caruthersville bend is strongly affected by the presence of a clay plug on the western channel margin, and 


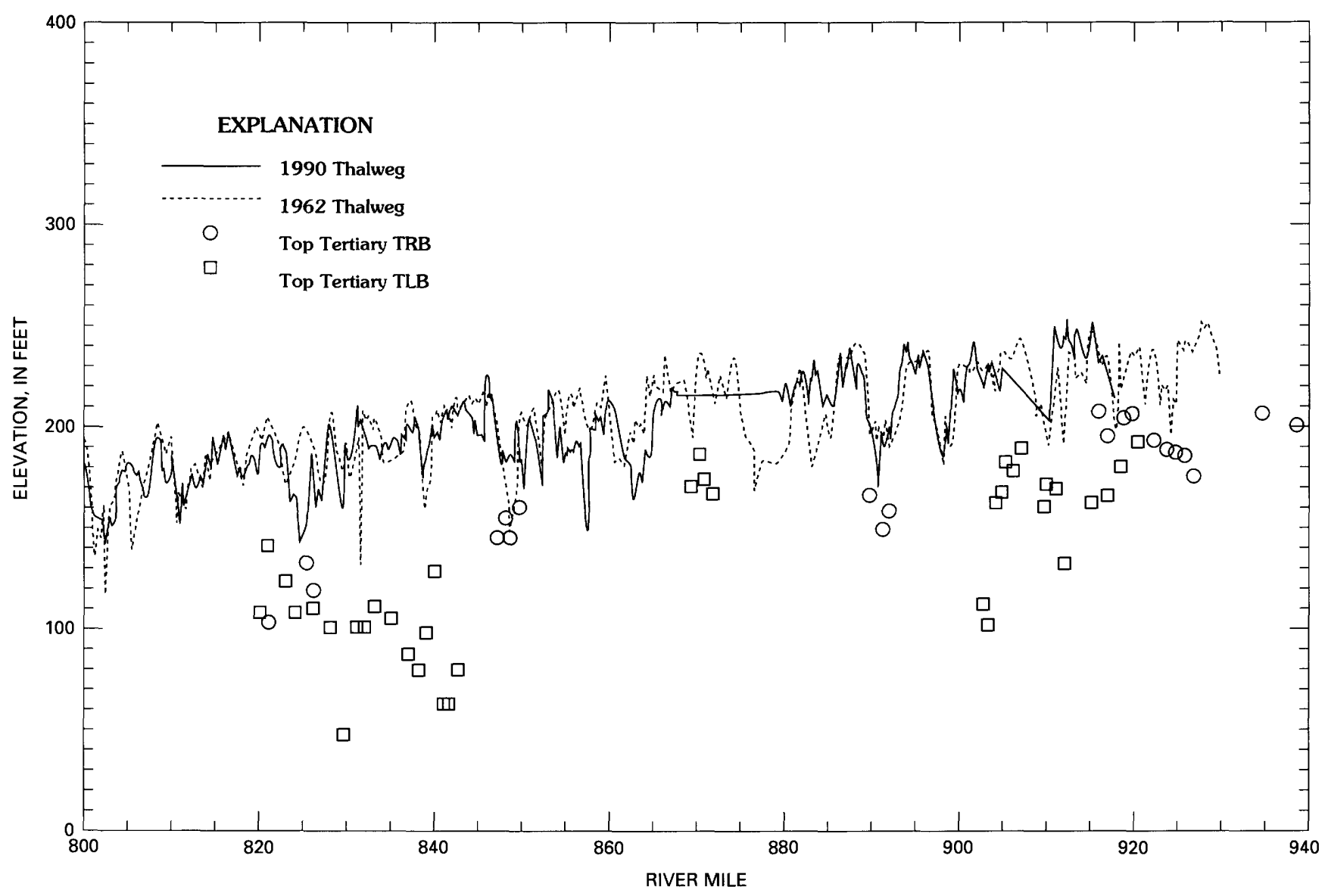

Figure 14. Elevation of top of Tertiary sediments from borings on right bank (TRB) and left bank (TLB) in relation to 1962 and 1990 Mississippi River thalweg profiles. See text for definition of river mile.

apparently Tertiary units are exposed in the channel bed (fig. 14). The bend lies along the crest of the Pascola arch and margin of the Blytheville arch; however, there is no conclusive structural evidence to suggest that uppermost Tertiary rocks are deformed at Caruthersville. As noted earlier, there is a marked $50-\mathrm{ft}$ thinning of alluvium at the western end of the Caruthersville bend (Obermeier, 1989, plate 7). This Tertiary high extends from the Caruthersville bend to the southwest, and it coincides with the Blytheville arch (fig. 2). At Caruthersville, the exposure of Tertiary units in the bed has probably maintained the bed elevation.

The abrupt steepening of the projected-channel profile at the boundary between Reach 5 and Reach 6 (RM 826; figs. $5 B$ and 7) and the compensating increase of sinuosity (fig. 6) and channel width-to-depth ratio, marks a dramatic change between Reaches 5 and 6 . Reach 6 is laterally active and sinuous relative to Reaches 5 and 7 . The reach has an anomalously steep projected-channel profile and a locally steepened water-surface profile at RM 820. A fault crossing has been proposed within the reach at RM 819 (Heyl and McKeown, 1978).

Similar changes of projected-channel slope and stream pattern occur at the Reach 7 and Reach 8 boundary (figs. $5 B$,
6, and 7) just north of Osceola, Ark. (RM 791). The significant changes of Mississippi River character suggest that an external influence has modified the channel. No faulting has been detected, but the river encounters Tertiary-age sediments in the Chickasaw Bluffs (fig. $5 B$ ), and this "bedrock" may be the controlling factor in this reach.

\section{GEOMORPHOLOGY OF THE WESTERN ALLUVIAL VALLEY}

If the Mississippi River responds to tectonically altered flood-plain slopes, then smaller rivers on the adjacent flood plain should also respond in a similar fashion-this was demonstrated for several streams crossing the Monroe uplift in Louisiana and the Wiggins uplift in Mississippi (Burnett and Schumm, 1983). However, any interpretation of anomalous river patterns and behavior must consider the influence of Pleistocene sedimentary deposits as well as old courses and deposits of the Mississippi River and human influences. Therefore, the several anomalous situations that are discussed below require further study before a tectonic cause can be confirmed. 


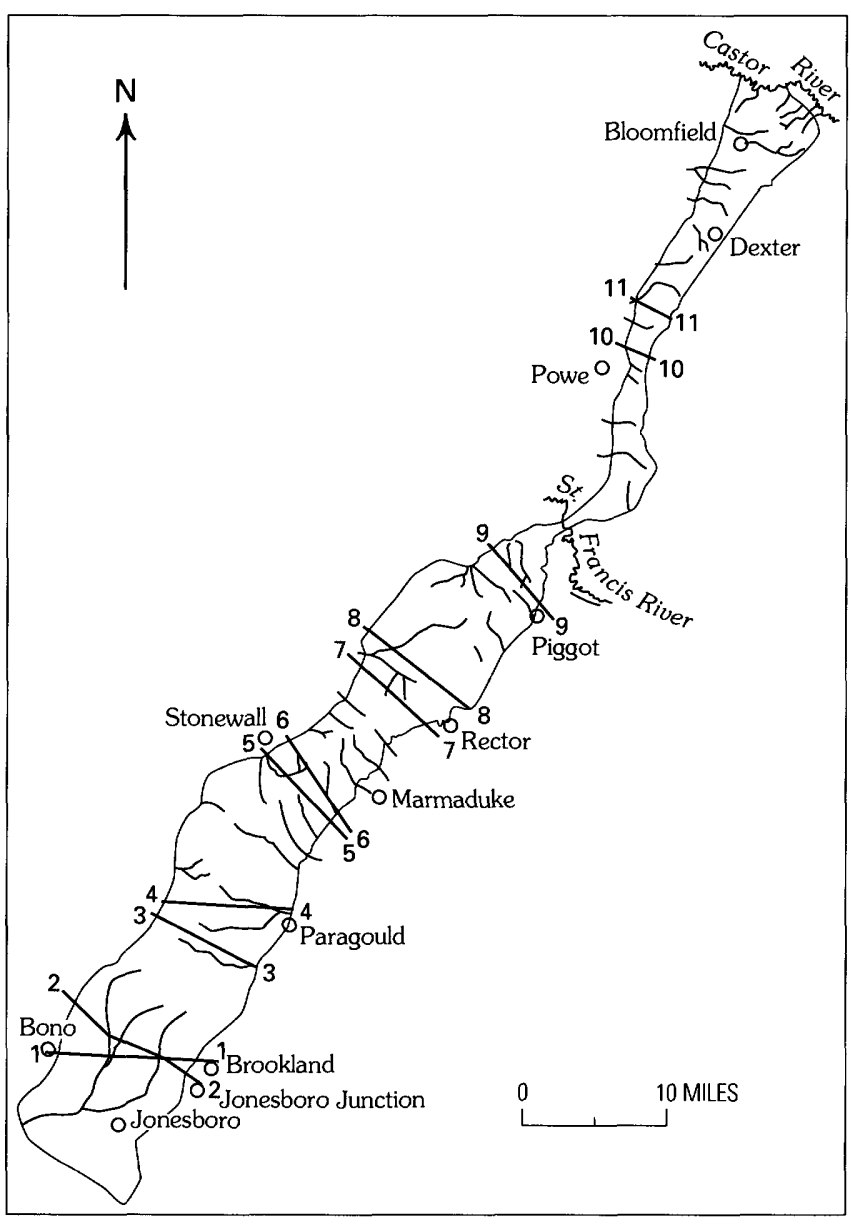

Figure 15. Index map of northern part of Crowleys Ridge, from the Castor River, in Missouri, to Jonesboro, Ark., showing general drainage patterns and location of numbered topographic profiles.

\section{RIDGES}

Erosional processes such as mass wasting, weathering and fluvial erosion tend to leave irregular topographic patterns. Therefore, when linear features are observed, an assumption that there is a lithologic or structural control is a reasonable conclusion. Two major topographic features dominate the very flat Mississippi River alluvial valley. Sikeston Ridge trends north from New Madrid, Mo., and Crowleys Ridge forms a divide in the western part of the alluvial valley from Helena, Ark., almost to Cape Girardeau, Mo. (fig. 1).

Sikeston Ridge rises $20 \mathrm{ft}$ above the adjacent alluvial plain. The southern end is irregular with crescentic scars, which are a result of Mississippi River erosion. From its southern end, Sikeston Ridge narrows from about $1.2 \mathrm{mi}$ to $0.5 \mathrm{mi}$ to the north for $12 \mathrm{mi}$ and then maintains a width of $21 / 2 \mathrm{mi}$ for an additional $11 \mathrm{mi}$. The east and west margins of the ridge are very straight, which suggests a structural control (Sikeston, New Madrid, and Bayouville 71/2-minute topographic quadrangles). Sikeston Ridge is generally concluded to be formed by erosion by braided streams (Russ, 1982, p. 99), but even braided streams would be expected to develop more irregular margins of the ridge. Hamilton and Zoback (1982, p. 61) identified a seismic reflection profile discontinuity where their profile S-11 crosses the western edge of Sikeston Ridge, which suggests that additional geophysical work along Sikeston Ridge is warranted.

Crowleys Ridge (figs. 1 and 15) has been attributed to Pleistocene deposition and erosion, but examination of the drainage patterns and relief variations along Crowleys Ridge strongly suggests that it also has major structural controls (Fisk, 1944, fig. 6). Cox (1988a) recognized that the character of Crowleys Ridge changes abruptly south of Jonesboro, Ark., where the Bolivar-Mansfield tectonic zone crosses it (Cox, 1988b). He notes that the ridge north of lat $35^{\circ} 45^{\prime} \mathrm{N}$. is asymmetrical and steeper on the west side, which suggests east-southeast tilting. Cox (1988a) suggests that Crowleys Ridge north and south of lat $35^{\circ} 45^{\prime} \mathrm{N}$. is composed of two separate structural blocks. In support of these ideas, seismic reflection lines that cross the margin of Crowleys Ridge at the northern end of the southern segment and in the latitude of Jonesboro reveal faulting of Paleozoic and Eocene rocks at the ridge margin, especially south and west of Jonesboro (Nelson and Zhang, 1991; VanArsdale and others, 1992).

The studies by Cox (1988a, 1988b) and VanArsdale and others (1992) suggest that Crowleys Ridge near Jonesboro, Ark., is fault controlled. The morphology of the ridge to the north, as described above, suggests that this structural control extends to its northernmost extent. The drainage pattern on Crowleys Ridge and a series of topographic profiles that show general topographic characteristics support this contention (fig. 16). For example, streams that drain Crowleys Ridge directly north of Jonesboro approximately parallel the trend of the ridge. They appear to have developed along zones of weakness that have separated the ridge into three distinct structural units. Profiles 1 and 2 (fig. 16) cross Crowleys Ridge in this area, and they suggest that it is composed of three fault blocks that dip to the east. Each segment has a relatively steep west-facing escarpment. Erosional modification of the ridge has made these relations less obvious on profile 2 , and, in fact, the three segments of the ridge may reflect stream incision shifting to the east.

Crowleys Ridge from south of Paragould to Rector, Ark. (fig. 15), has a scarp that faces west and a drainage divide that is on the western side of the ridge, which suggests that this segment of the ridge may be an east-dipping fault block (fig. 16). For example, profiles 3,5 , and 6 (fig. 16) have a scarp on the west side of the ridge and a less well defined margin to the east. Profile 4 has a similar asymmetric shape, but the eastern edge of the ridge is better defined than in profile 3.

From Rector, Ark., to the water gap of the St. Francis River (fig. 15), the drainage divide is in the center of the ridge. Note also that the eastern and western margins of the ridge are both abrupt slopes, which may be evidence of 
(1) BONO (West) TO BROOKLAN (East)

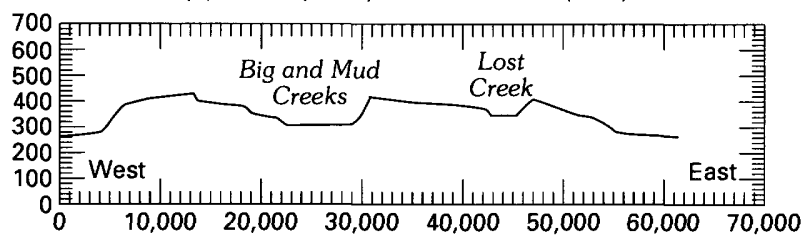

(2) NEAR FIFTYSIX (NW) TO JONESBORO JCT. (SE)

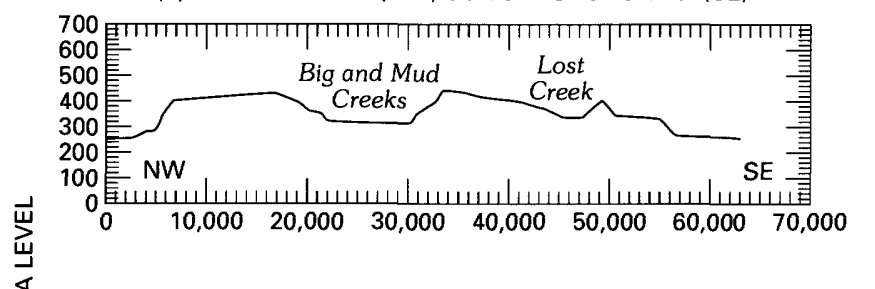

(3) WALCOTT (NW) TO GREENE HIGH (SE)

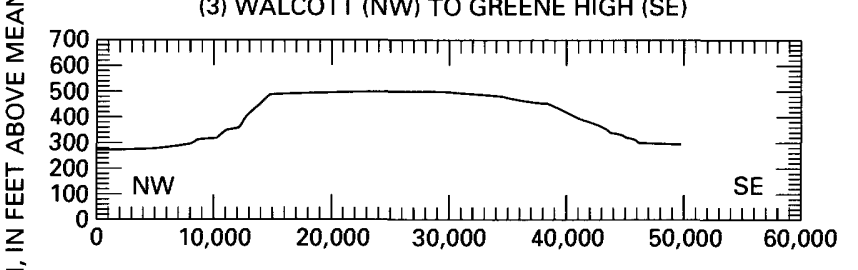

(4) WALCOTT (West) TO PARAGOULD (East)

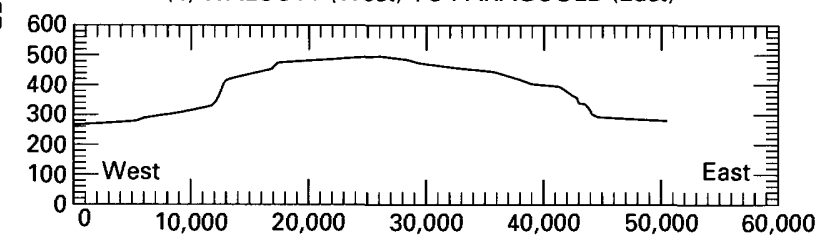

(7) TIPPERARY (NW) TO RECTOR (SE)

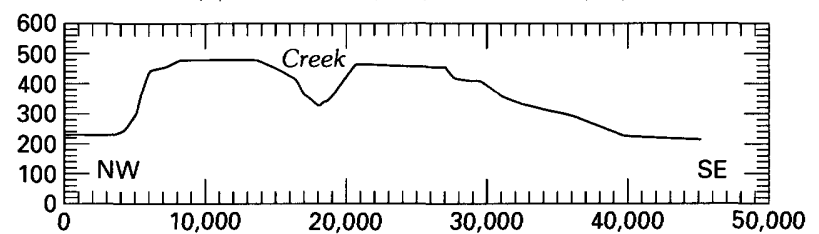

(8) N. OF LOWER BOYDSVILLE (NW) TO PRATT (SE)

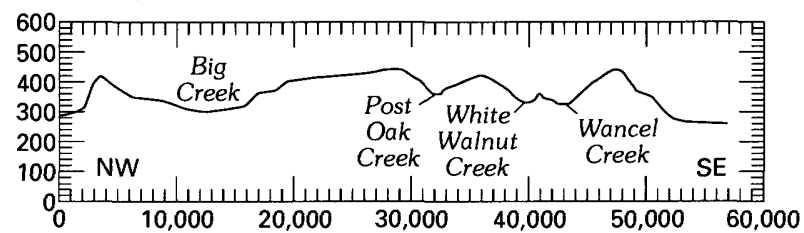

(9) N. OF HORSE CREEK (NW) TO PIGGOTT (SE)

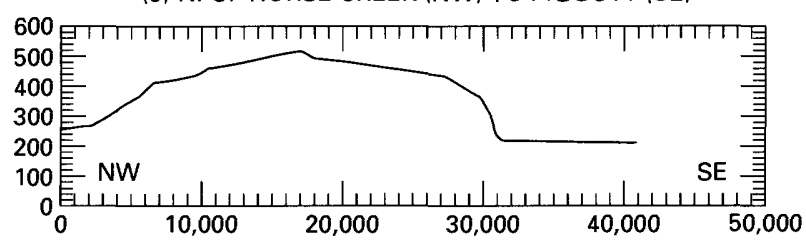

(10) NORTH OF POWE (NW TO SE)

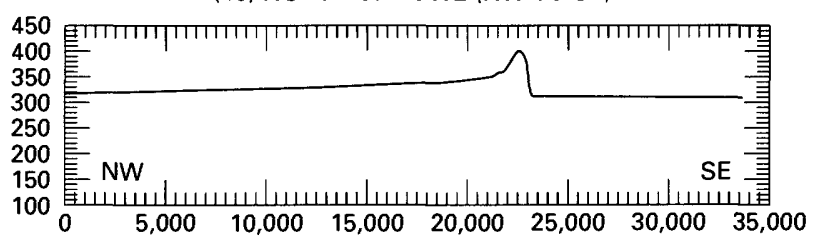

$(5,6)$ STONEWALL (NW) TO HWY (SE)

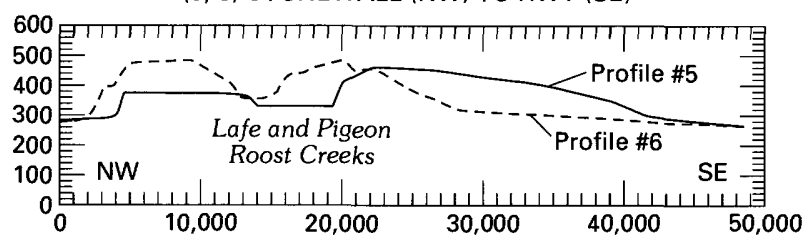

(11) WEST OF PYLETOWN (NW TO SE)

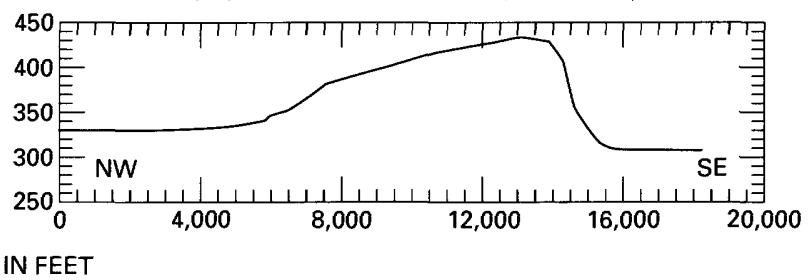

Figure 16. Topographic profiles 1-11, Crowleys Ridge. See figure 15 for profile locations.

uniform uplift, although profile 9 (fig. 16) shows a better defined east-facing scarp.

The ridge narrows and its morphology changes between the St. Francis River and the Castor River (fig. 15). Along this part of the ridge, there is an east-facing scarp, and the divide is on the east side of the ridge (fig. 16). This geomorphology suggests that this segment of the ridge may be a fault block dipping to the west.
In summary, drainage asymmetry and ridge-margin declivity along Crowleys Ridge may be the result of tilting due to faulting. In a northern direction, it changes from an easterly sloping three-segment ridge with a steeper western margin (profiles 1 and 2, fig. 16) to a single east-sloping ridge with a west-facing scarp (profiles $3,5,6$, and 7 , fig. 16) to a dissected plateau (profiles 8,9 , fig. 16) to a less well defined ridge with an east-facing scarp and westerly slope 


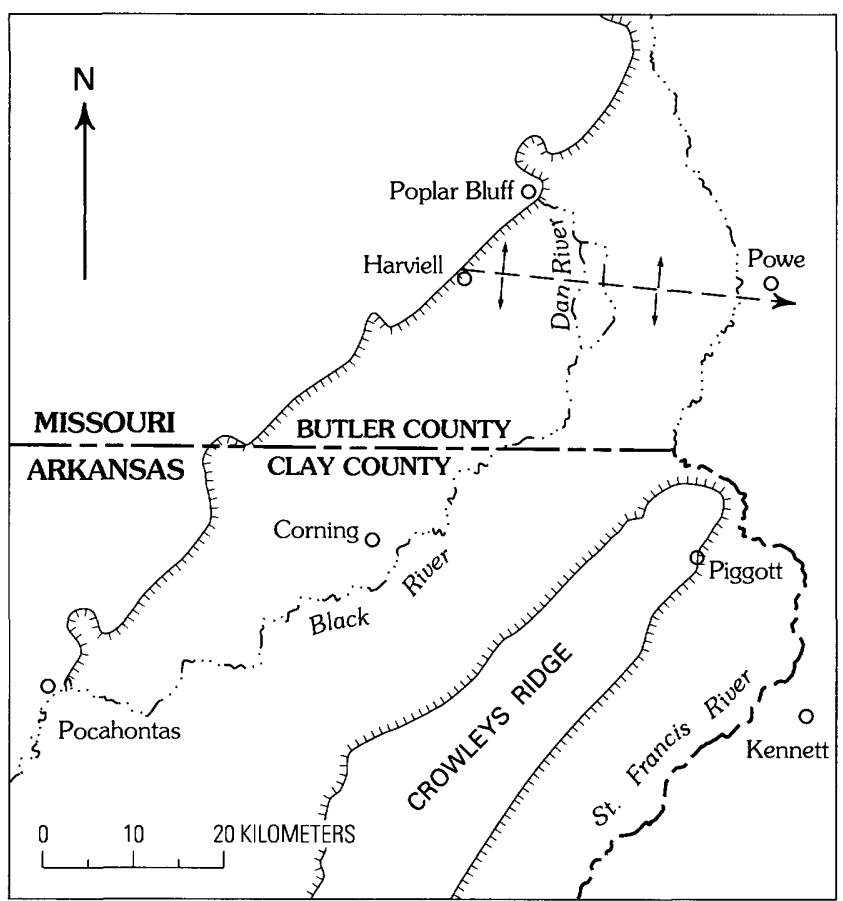

Figure 17. Map showing anomalous courses of Black and St. Francis Rivers. Dashed line shows approximate location of inferred uplift.

(profiles 10, 11, fig. 16). The degree of ridge dissection suggests that considerable erosion has occurred since major faulting, but the linearity and sharpness of portions of the ridge margins suggests that faulting along the ridge margins occurred during the Quaternary Period.

In conclusion, the morphologic character of both Sikeston Ridge and Crowleys Ridge suggest structural controls for at least parts of both features. In fact, Fisk (1944, p. $22,24)$ suggested that the straightness of the western margin of Crowleys Ridge reflected faulting and that the gaps in the ridge correspond with the position of east-west fault zones. It appears that the structural controls identified by Cox (1988a, 1988b) and VanArsdale and others (1992) extend to the north.

\section{BLACK RIVER ANOMALIES}

The Black River (fig. 17) leaves the western bluff line at Poplar Bluff, Mo. It flows southeasterly for 3 or $4 \mathrm{mi}$ and then turns southwesterly along a easterly convex course (Harviell, Missouri, 71/2-minute quadrangle). This pattern is mirrored by the St. Francis River, which is east of Black River (fig. 17). Their arcuate courses are striking, but of more interest is the flow history of the northern half of Dan River (fig. 18). Although Dan River is a continuous channel on figure 18, it is segmented by a drainage divide extending west from Big Island School. Because Dan River is an abandoned channel of the Black River, the flow should be to the south, however,

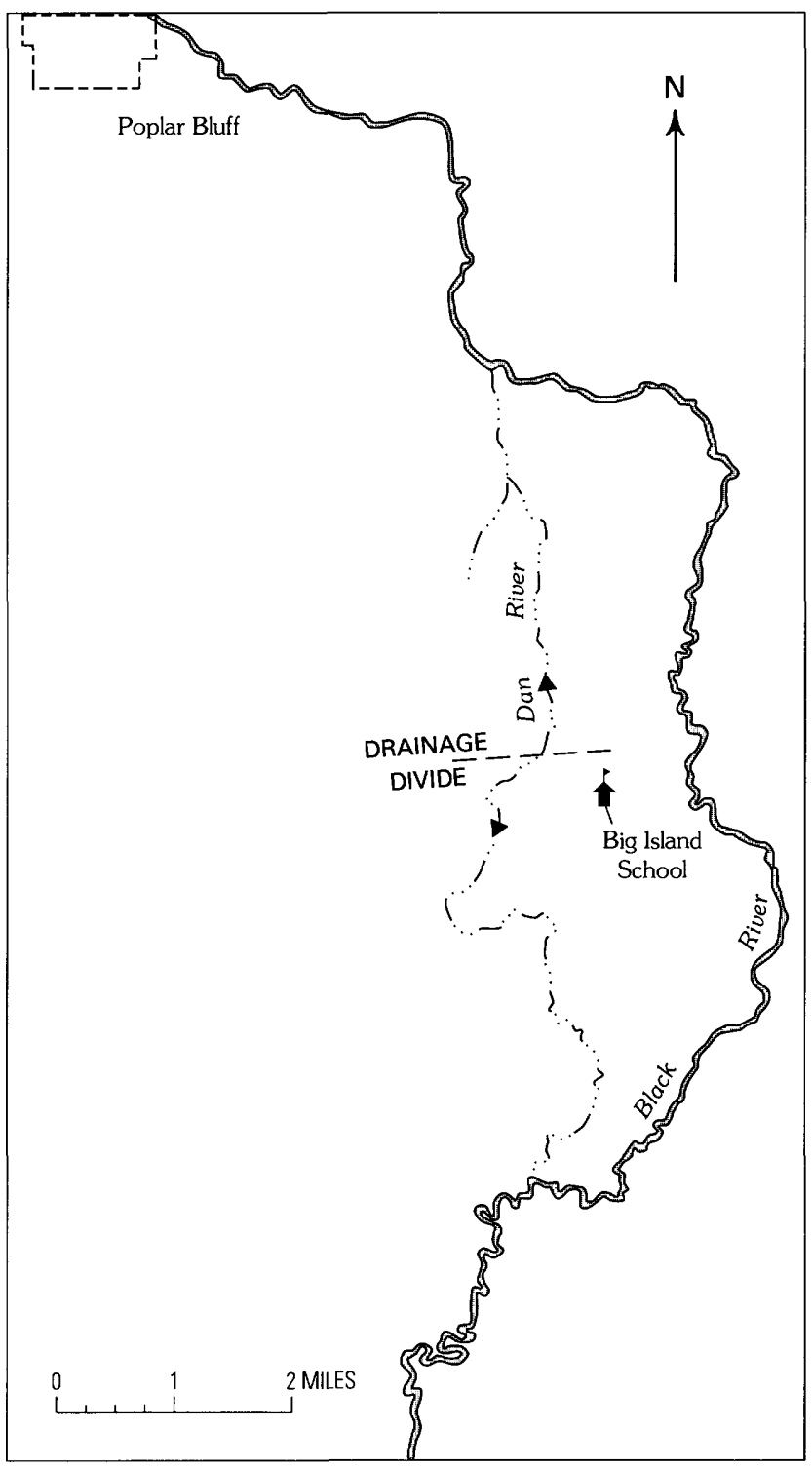

Figure 18. Map showing anomalous patterns of Black and Dan Rivers. Note tributary to Dan River that suggests flow to the north.

topographic contours and tributary junctions indicates that part of the river flow is to the north (Harviell, Missouri quadrangle). The Dan, Black, and St. Francis Rivers, anomalous patterns suggest an upwarping along an east-west axis to the west of Big Island School (fig. 18) and perhaps between Harviell and Powe, Mo. (fig. 17).

Although the Black River's general trend is southwest in figure 17, its course is composed of a series of essentially north-south and east-west reaches. This angular pattern (rectangular drainage) is very similar to that of streams with courses controlled by faults or joints. Thus, the Black River contains river-pattern anomalies that suggest structural control, but the origin of the apparent control is unknown. 


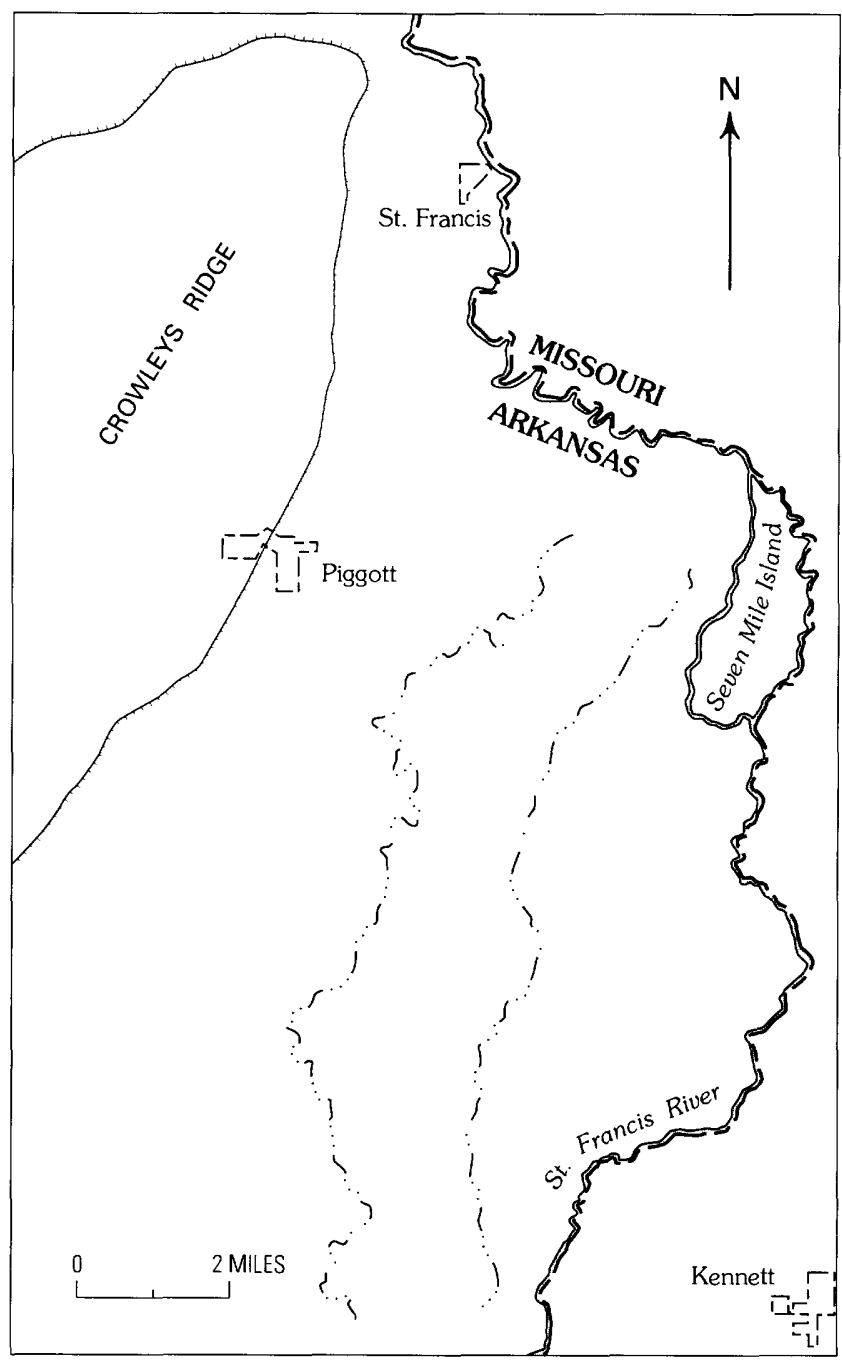

Figure 19. Map showing present course and old abandoned courses of St. Francis River

\section{ST. FRANCIS RIVER ANOMALIES}

The St. Francis River leaves the western bluff northeast of Poplar Bluff, Mo., and, as noted above, it follows an arcuate course similar to Black River to the south until it cuts southeastward through Crowleys Ridge (fig. 17) at a point that coincides with the axis of the Pascola arch, as projected from the Caruthersville bend (Piggott, Arkansas, 71/2-minute quadrangle). After passing through Crowleys Ridge, it turns to the southeast and then back to the southwest (fig. 17). Old courses of the St. Francis River southeast of Piggott, Ark., show that the river has progressively migrated to the east (fig. 19). The bifurcation of the modern channel east of Piggott to form Seven Mile Island suggests that this eastward migration is continuing. Such avulsive changes can be a natural aspect of river behavior, but it can also reflect a subtle tilting of the flood plain to the east, which could be caused by uplift in the Ozark Mountains (McKeown and others, 1988).

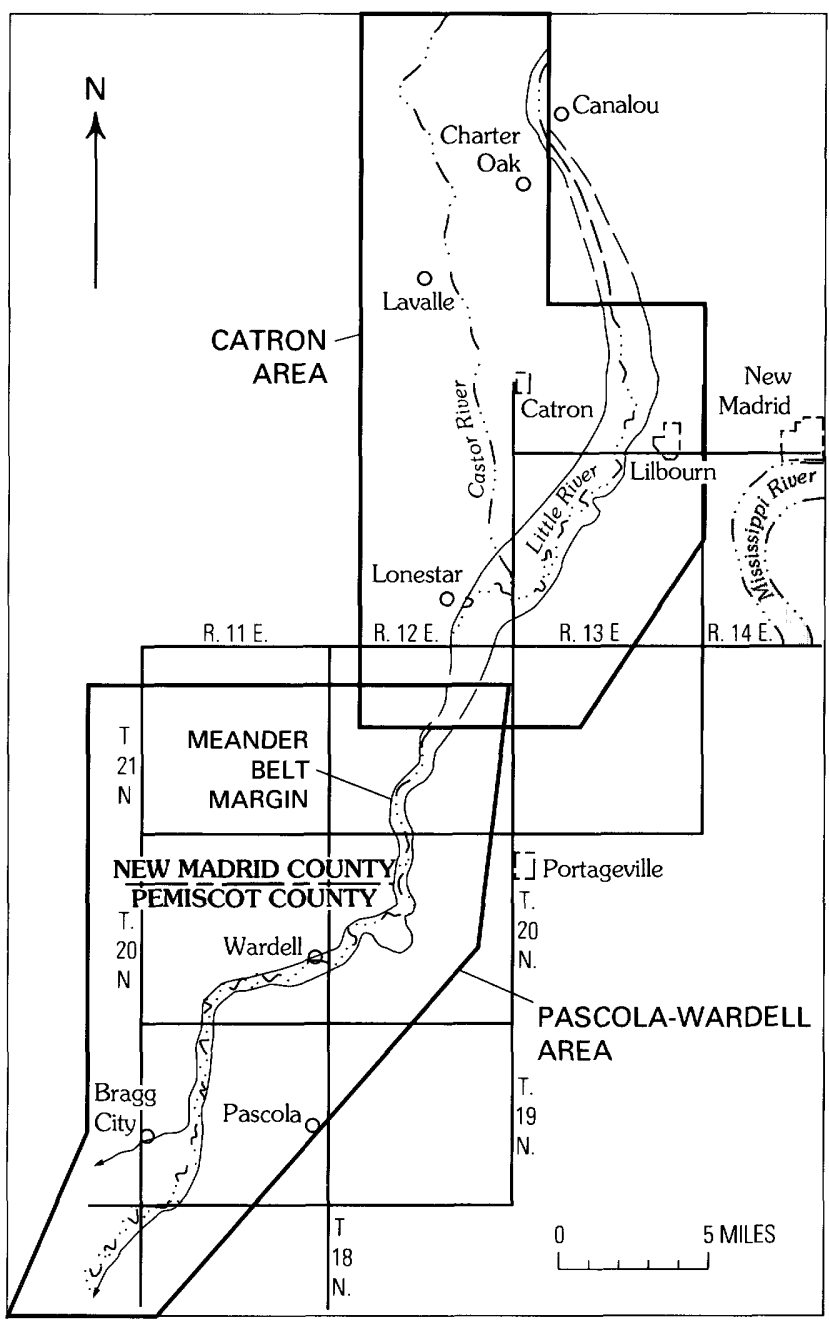

Figure 20. Map showing course of Little River and meander belt width as mapped in the 1870's. Also shown are two main areas of Little River Drainage District evaluated in this study.

\section{LITTLE RIVER ANOMALIES}

The Little River flows generally to the south (New Madrid, Missouri, 71/2-minute quadrangle) past New Madrid and Lilbourn, Mo., and turns abruptly west near Lonestar, Mo. (fig. 20). Its meander belt, as surveyed in 1870 , was about 1 to $1 \frac{1}{2}$ mi wide. However, to the south, the meander belt narrows (fig. 20), and near the New Madrid-Pemiscot County line, the Little River makes a 6-mi deflection to the west past Wardell, Mo., where the meander belt is only $1 / 4$ mi wide. It then turns abruptly south for $6 \mathrm{mi}$ to the southern edge of the Pascola, Missouri, 71/2-minute quadrangle. East of Bragg City, Mo., the meander belt widens abruptly to $2 \frac{1}{2}$ $\mathrm{mi}$. These changes of direction and meander-belt width suggest that the river may be affected by changes in local topography or by surficial sediments.

To identify possible structural controls on the course of the Little River, survey data were obtained from the Little 


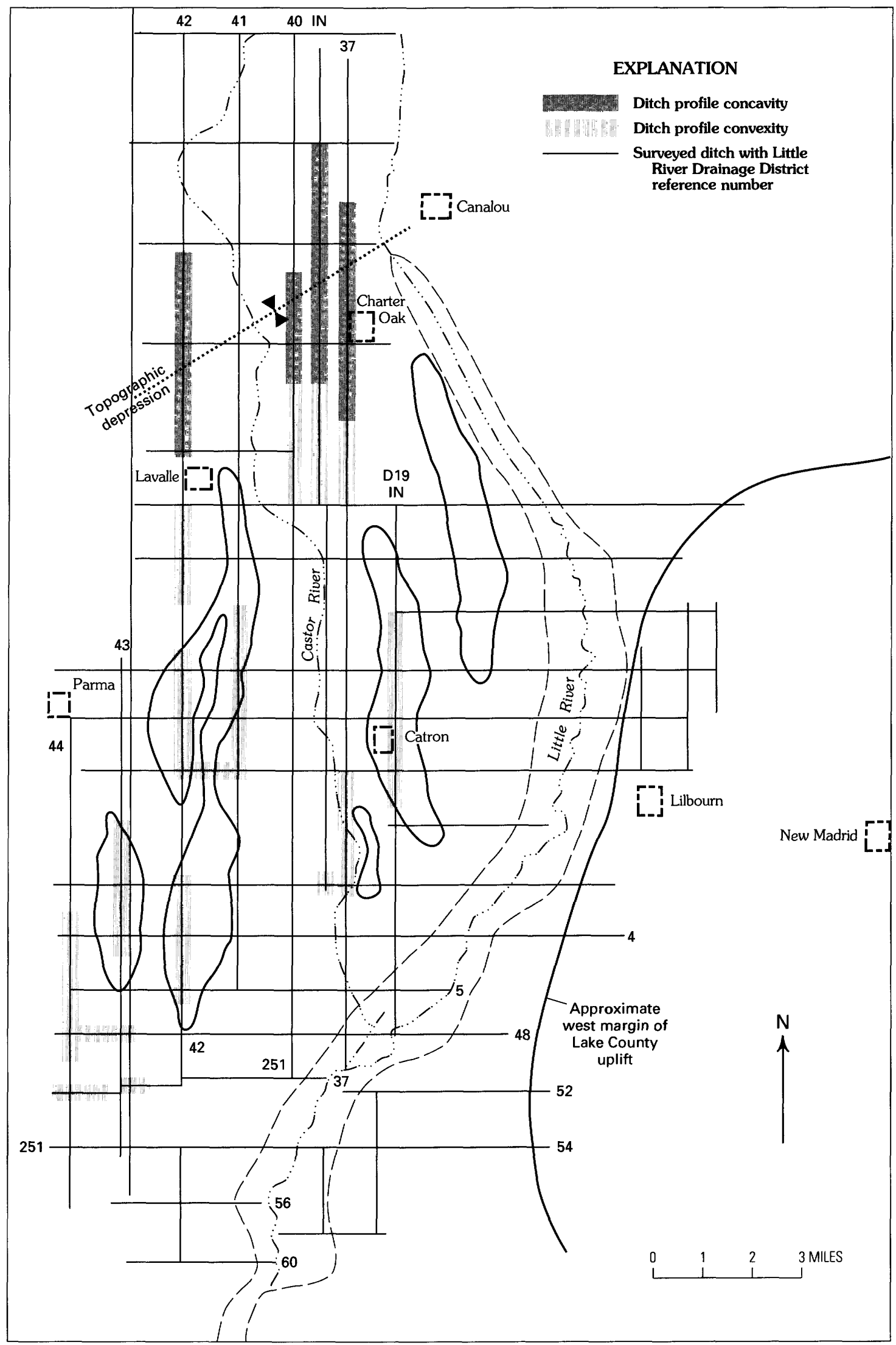

Figure 21. Location map showing drainage ditches, topographic anomalies, and braided-stream deposits (heavy lines) in Catron area of Little River Drainage District. 


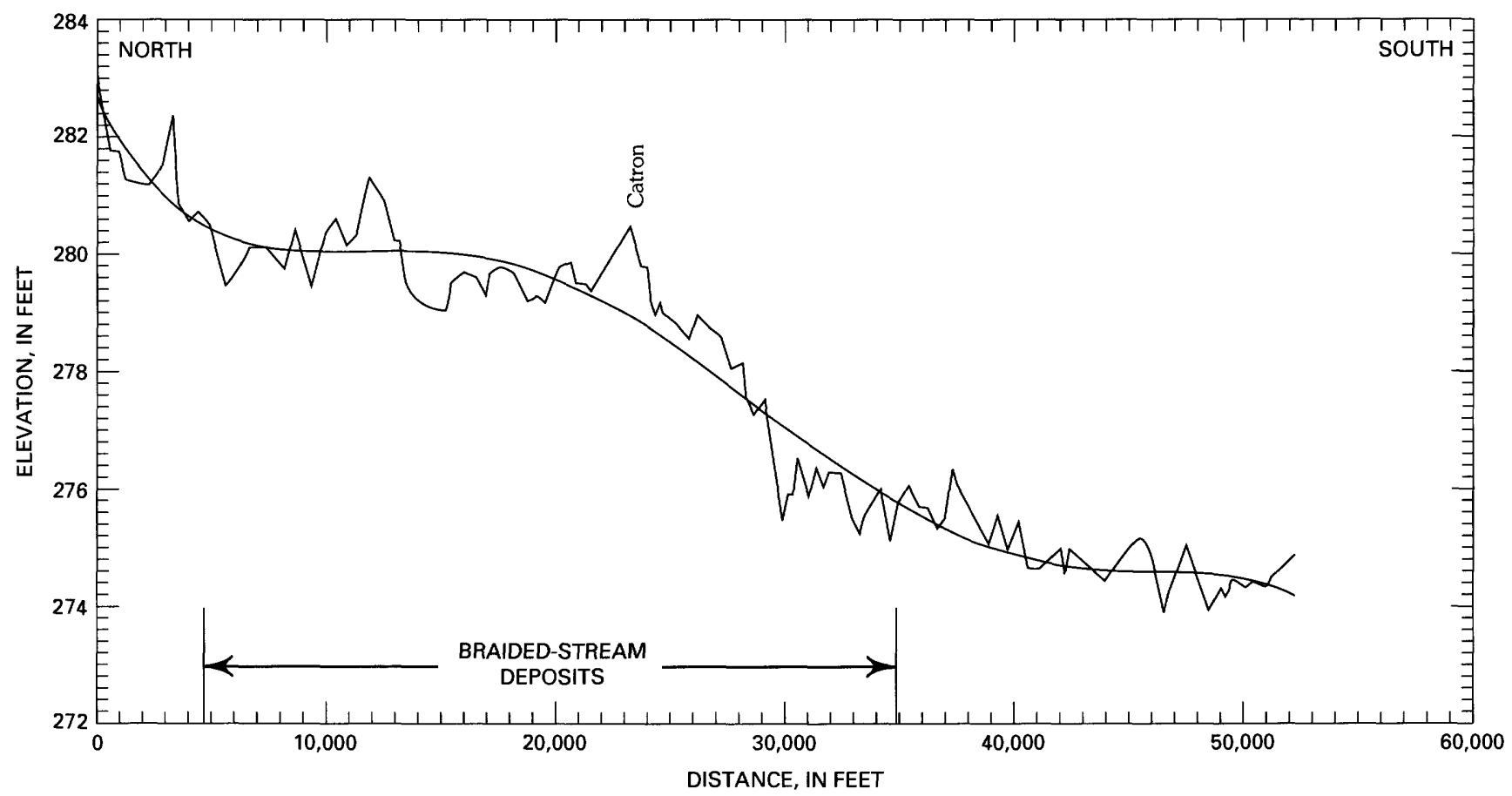

Figure 22. North-south surveyed profile of District 19, Ditch 1 North (in fig. 21) showing convexity in vicinity of Catron, Mo.

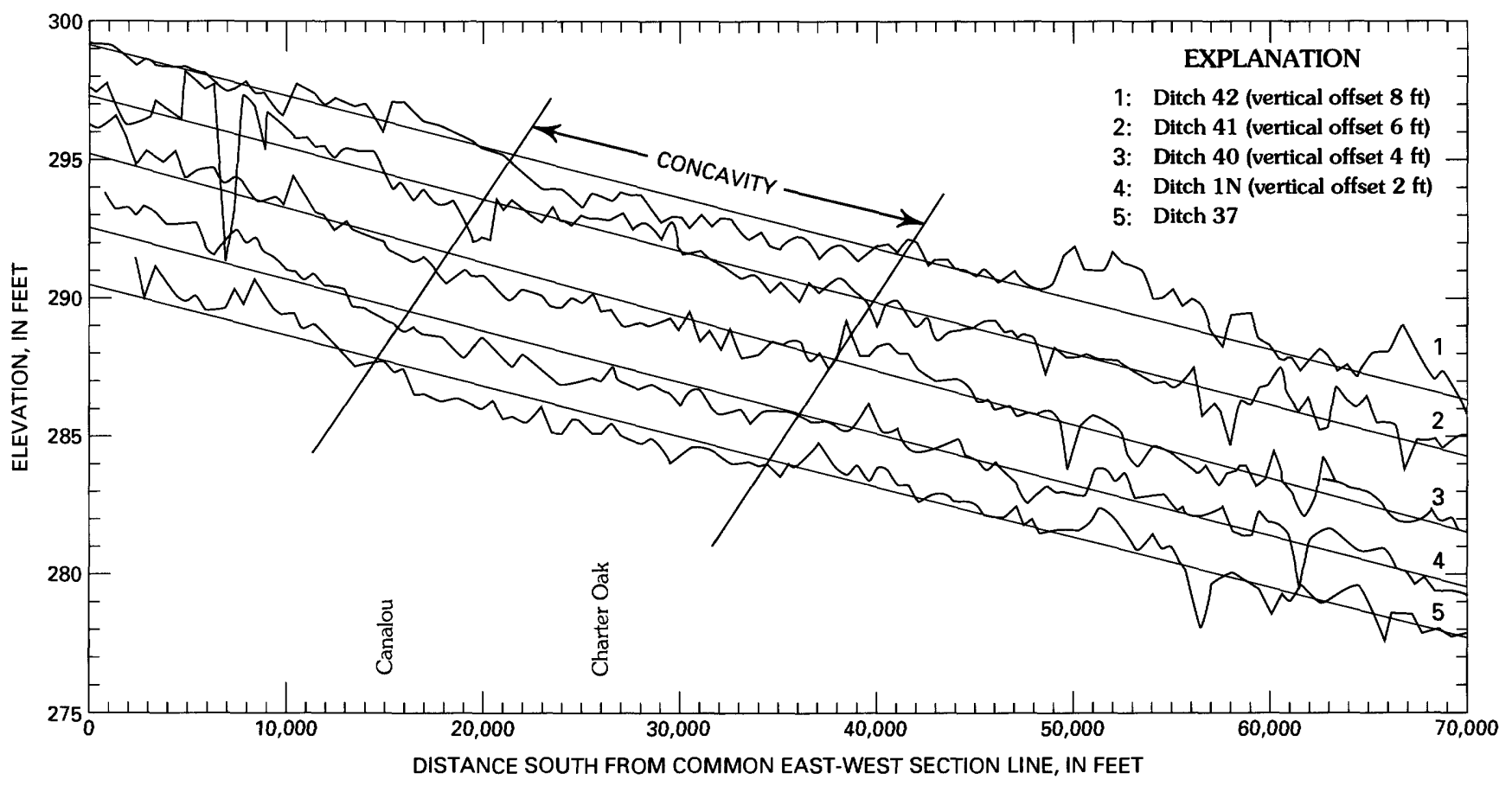

Figure 23. Surveyed profiles and linear best-fit lines of four north-south-trending ditches near Charter Oak and Canalou, Mo. Profiles are offset vertically to prevent overlap. 


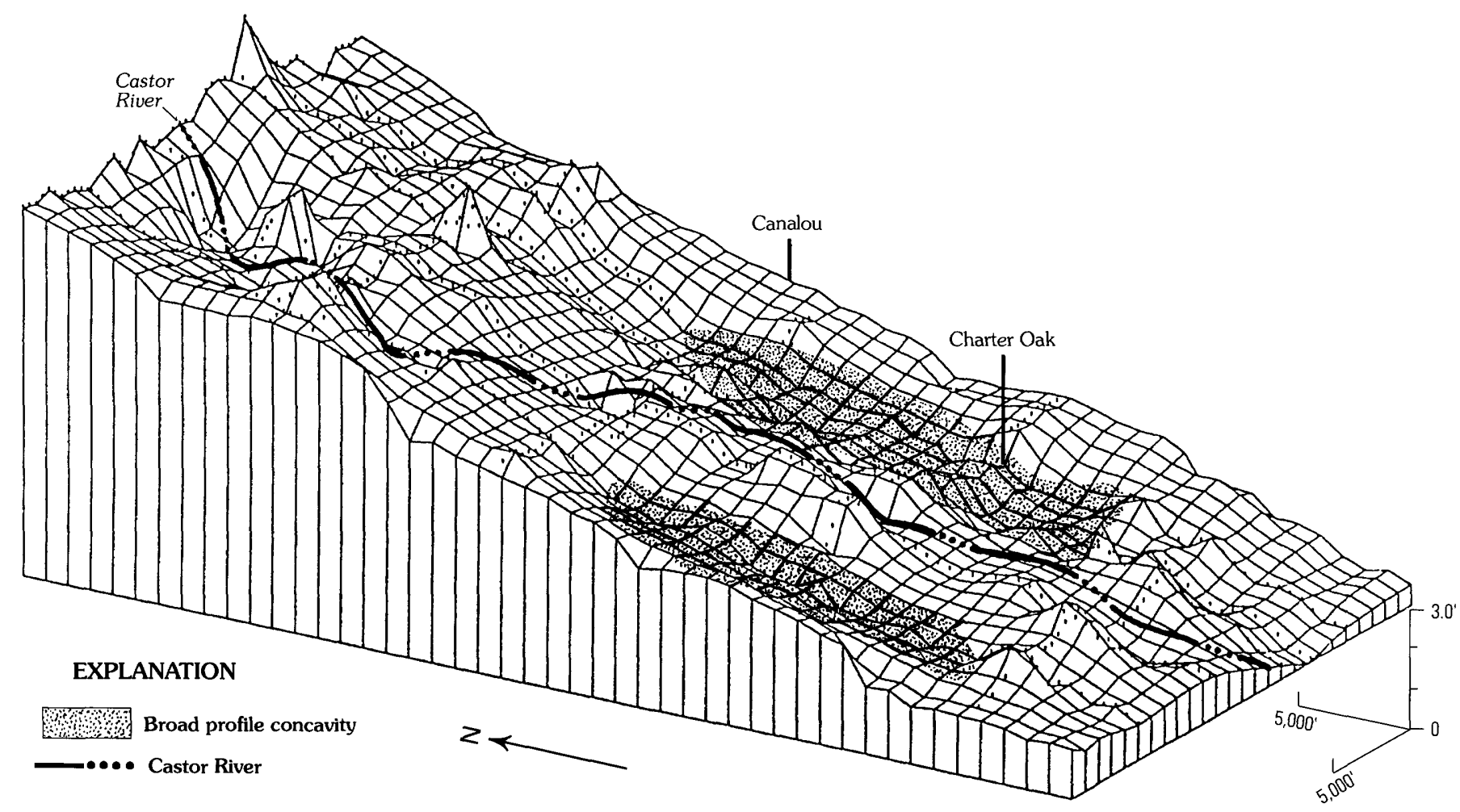

Figure 24. Topographic plot of northern Catron area, showing topographic depressions (shaded) between Canalou and Charter Oak, Mo.

River Drainage District (LRDD). The earliest ditch construction in the LRDD began in 1914 and was completed in 1920. In 1924, the drainage plan was revised and the existing and planned ditches were surveyed. The survey consisted of measuring ground-surface elevations approximately every $500 \mathrm{ft}$ along the ditches to $0.1-\mathrm{ft}$ precision. The 1924 survey was conducted prior to intense pumping of ground water for irrigation in the region, so the impact of man-induced surface deformation along the profiles should be relatively low. The 1924 survey has been analyzed for evidence of surface deformation by construction of two-dimensional profiles and three-dimensional relief maps.

Two main areas of the Little River Drainage District were chosen for detailed analysis, because they contain the course of the Little River and its meander belt and because the 1924 ditch profiling was relatively dense in these areas. The first area is west of New Madrid, Mo.; it extends from approximately Canalou, Mo., in the north to Lonestar, Mo., in the south (fig. 20). The town of Catron, Mo., is located approximately in the center of the area; hence it will be referred to as the "Catron area." The second area is to the south, in the vicinity of Wardell, Pascola, and Bragg City, Mo., where the Little River makes an abrupt turn to the south and flows within a narrow meander belt (fig. 20). This will be referred to as the "Pascola-Wardell area." The primary objectives of the topographic analysis are: (1) to characterize topography in each area, (2) to evaluate the influence of topographic features on drainage patterns, and (3) to consider the causes of any identified topographic anomalies.

Catron Area.-Within the Catron area, the Little River flows south past Canalou and Charter Oak, Mo., and then continues southward in a broad easterly arc past the town of Lilbourn, Mo., and toward Lonestar, Mo. The 1924 maps also show the course of the Castor River, which flows approximately due south through the Catron area and joins the Little River in the southern portion of the area (fig. 20). Figure 21 shows the ditches that were surveyed, as well as any upward concavities or upward convexities observed on the plotted profiles. There is minimal convexity associated with the Little River meander belt, indicating that natural levee development adjacent to the river is minor. West of the river, however, numerous profiles display convexities. To aid in the discrimination between depositional features and surface deformation, geologic and soil-survey maps were utilized to identify locations of Wisconsin-age braidedstream deposits that form topographic highs on the Little River surface. Figure 21 shows the braided-stream deposits as mapped on the soil survey (Brown, 1971).

Based on the mapped distribution of braided-stream deposits, it is evident that the majority of convexities observed on the ditch profiles are directly related to natural depositional features rather than to tectonic deformation. 


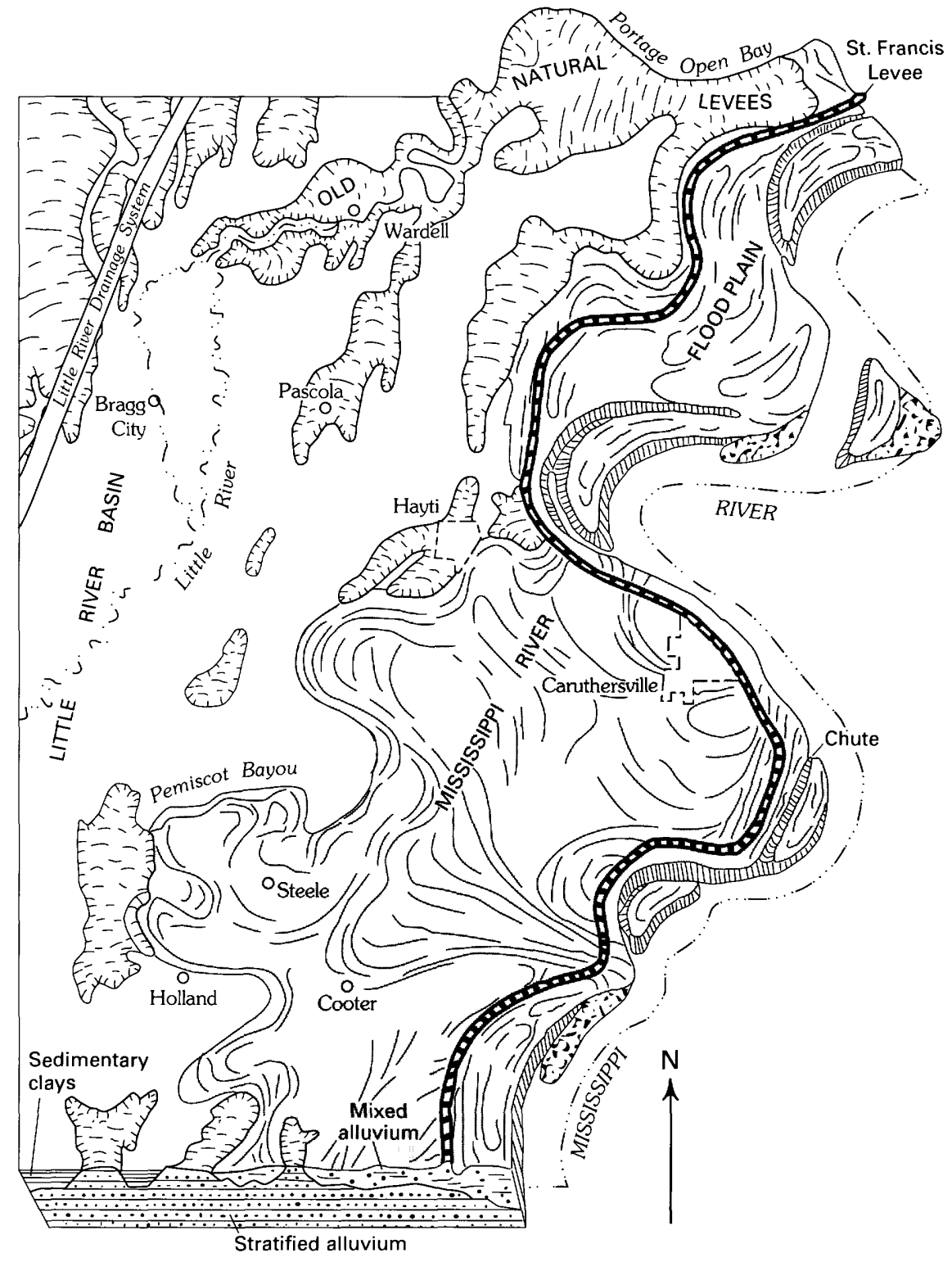

Figure 25. Physiography of Pemiscot County, Missouri (from Brown, 1971).

Figure 22 shows an example of a ditch profile that is convex over mapped braided-stream deposits. Similar conditions between mapped braided-stream deposits and profile convexities for the remaining ditches indicate that depositional features are the primary control of topography in the area. However, in the northernmost Catron area, a series of ditch profiles display depressions where there are no previously mapped depositional features that created the topography (fig. 23). These profiles indicate the presence of a slight northeast-trending depression in the vicinity of Charter Oak, Mo., which may be the result of localized tectonic deformation, ground subsidence due to ground-water withdrawal, or an unmapped variability in surficial deposits. Ditch 41 , which runs through the same area along the Castor River, does not display the topographic anomaly, possibly due to sediment deposition along the river.

In order to obtain a topographic perspective of the Catron area topography, the ditch profiles were combined into an $X, Y, Z$ database, and surface-elevation plots were generated. Figure 24 shows the topography of the northern Catron area, near Canalou and Charter Oak, Mo. The plot highlights the areas of broad profile concavities as shown in two dimensions on figure 23 . Early 20 th century construction of drainage ditches has resulted in the diversion of most flow away from the Castor River, such that the ability of the river to adjust to topography has been diminished. If the 
depressions are the result of surface deformation, they are probably relatively recent because the river has not shifted into the topographic lows.

Surficial deposits in the area were not mapped during the course of this study; consequently, the relationship between alluvial deposits in the region should be mapped in detail and the intensity of ground-water withdrawal evaluated before a tectonic control on topographic variability is assumed.

Wardell-Pascola Area.-South of the Catron area, the Little River intersects Portage Open Bay. Portage Open Bay is a crevasse-splay channel of the Mississippi River that flows into the Little River (fig. 25). Natural levee deposits that bound the Little River in the Wardell, Mo., area are, therefore, largely related to Mississippi River overbank flows (fig. 25). Although historic surface deformation in the region is suggested by reports that navigation between Portage Open Bay and the Little River became impossible after the 1811-12 earthquakes, the loss of navigation capabilities has been attributed to extensive ground failure rather than regional surface deformation (Penick, 1981).

From its junction with Portage Open Bay to about $8 \mathrm{mi}$ southwest, the Little River flows primarily westward within natural levee deposits (fig. 25). As the river emerges from the natural levee deposits, it makes an abrupt turn southward. Topographic data were compiled in an effort to identify controls on the course of the Little River through the Wardell-Pascola area. Because the area has been historically characterized by poor drainage, numerous east-west ditches were constructed to drain water from the Little River flood plain to a main ditch (Ditch 251) that runs northeast-southwest toward the Arkansas State line. The locations of ditches in the area that were surveyed in 1924 and utilized in this analysis are shown in figure 26 .

A topographic plot of the area shows how natural levee deposits have created an overall westward-dipping slope (fig. 27). As the river passes Portage Open Bay, it turns west and flows down that slope. The river is bounded by natural levee deposits, as it crosses Ditches 64, 65, and 66 (fig. 26). It then turns south, emerging from the natural levee deposits as it crosses Ditches 68 through 71 . This southerly course is anomalous in that it is tangential to the overall southwesterly topographic gradient. An abandoned Little River channel segment, referred to as "Big Bayou" on the 1924 drainage district maps, leaves the Little River at the point of emergence from the natural levee deposits (figs. 26 and 27). This abandoned channel segment suggests that the Little River has avulsed eastward from Big Bayou. However, the surface plot of the Pascola-Wardell area does not show any obvious topographic features that may have caused the Little River to shift eastward from what is now Big Bayou to its present position.

Plotted ditch profiles from the Pascola-Wardell area show that profile convexities are generally located on natural levee deposits along the Little River, with the exception of a broad convexity on the main northeast-southwest-trending ditch (Ditch 251). Several profiles parallel to the ditch that were constructed using surveyed elevations from ditches running tangential to Ditch 251 show a similar convexity (fig. 28). The convexity trends northeast and runs subparallel to the mapped northwestern margin of the Reelfoot rift (fig. 26). Furthermore, it is located between the Reelfoot rift margin and the Bootheel lineament (fig. 26). This convexity may reflect surface deformation near Bragg City, Mo. This uplift may have affected the course of the Little River by causing abandonment of the Big Bayou channel and relocation of the Little River to the east.

\section{SUMMARY}

Numerous geomorphic features have been identified west of the Mississippi River, that may be related to surface deformation in the New Madrid seismic zone. Crowleys Ridge consists of at least four geomorphically discrete blocks that may be the result of structural segmentation. The Black River and St. Francis River all display abrupt course changes that may reflect upwarping and (or) tilting of their flood plains. Ditch-survey data that was collected in the Little River Drainage District during the 1920's have been used to identify topographic anomalies in the area. In most cases, these topographic anomalies reflect braided-stream and natural levee deposits. However, several anomalous areas were identified that do not correlate to such previously mapped deposits. Avulsion of the Little River off of the regional topographic gradient may reflect localized warping at the point of avulsion. The identified anomalies do not collectively form regular patterns, hence, they apparently do not delineate systematic deformational trends.

\section{SUMMARY AND CONCLUSIONS}

Numerous Mississippi River (figs. 7, 10, 11, 12), Black River (figs. 17, 18), St. Francis River (figs. 17, 19), and Little River anomalies (figs. 21, 26) have been identified in the Mississippi Embayment between Hickman, Ky., and Osceola, Ark. The identification of these anomalies offer direction for scientists who are using subsurface geological and geophysical data to locate areas of tectonic deformation in the New Madrid seismic zone.

The Mississippi River can be divided into reaches (fig. 1) that reveal the effect of the Lake County uplift (Reaches 3 and 4) and an inferred fault that crosses the river near the Reach 5 and 6 boundary (fig. 1), as mapped by Heyl and McKeown (1978). The boundary between Reaches 5 and 6 is also where the river crosses the southern boundary of the Blytheville arch (fig. 2). The Caruthersville bend appears to 


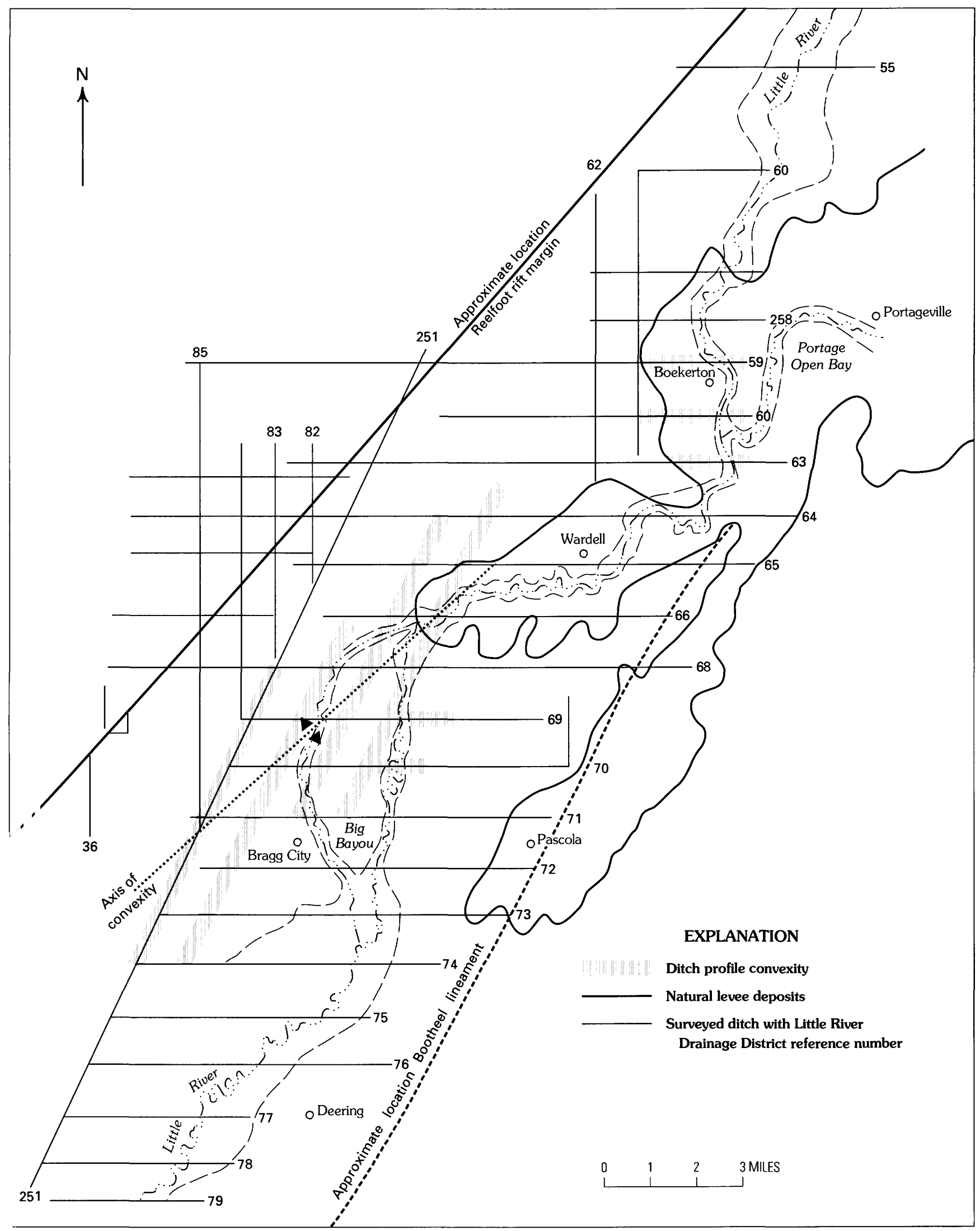

Figure 26. Location map of geomorphic features and available ditch surveys, Wardell-Pascola, Mo., area. 


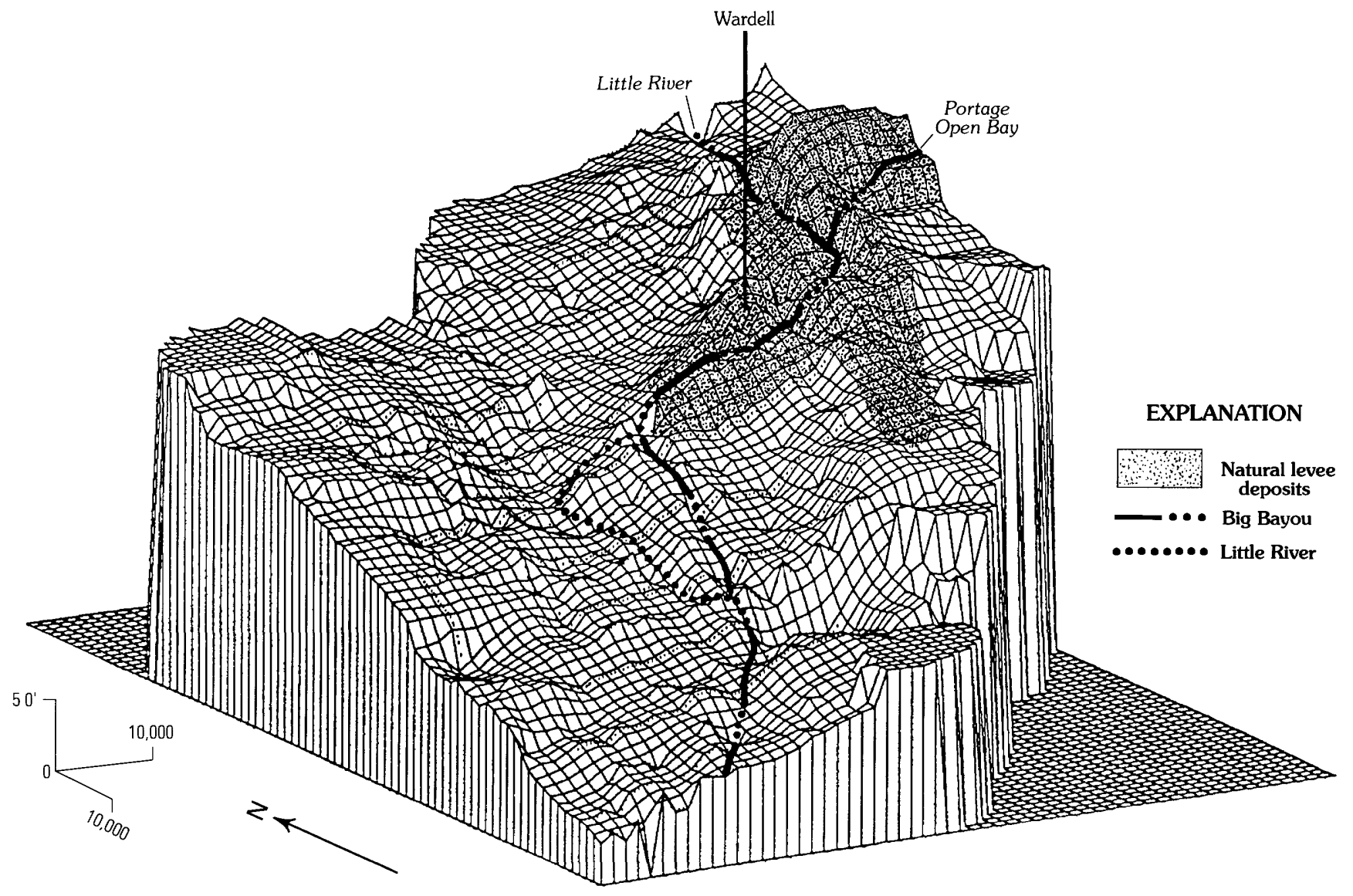

Figure 27. Topographic plot of Wardell-Pascola, Mo., area showing geomorphic features and course of Little River.

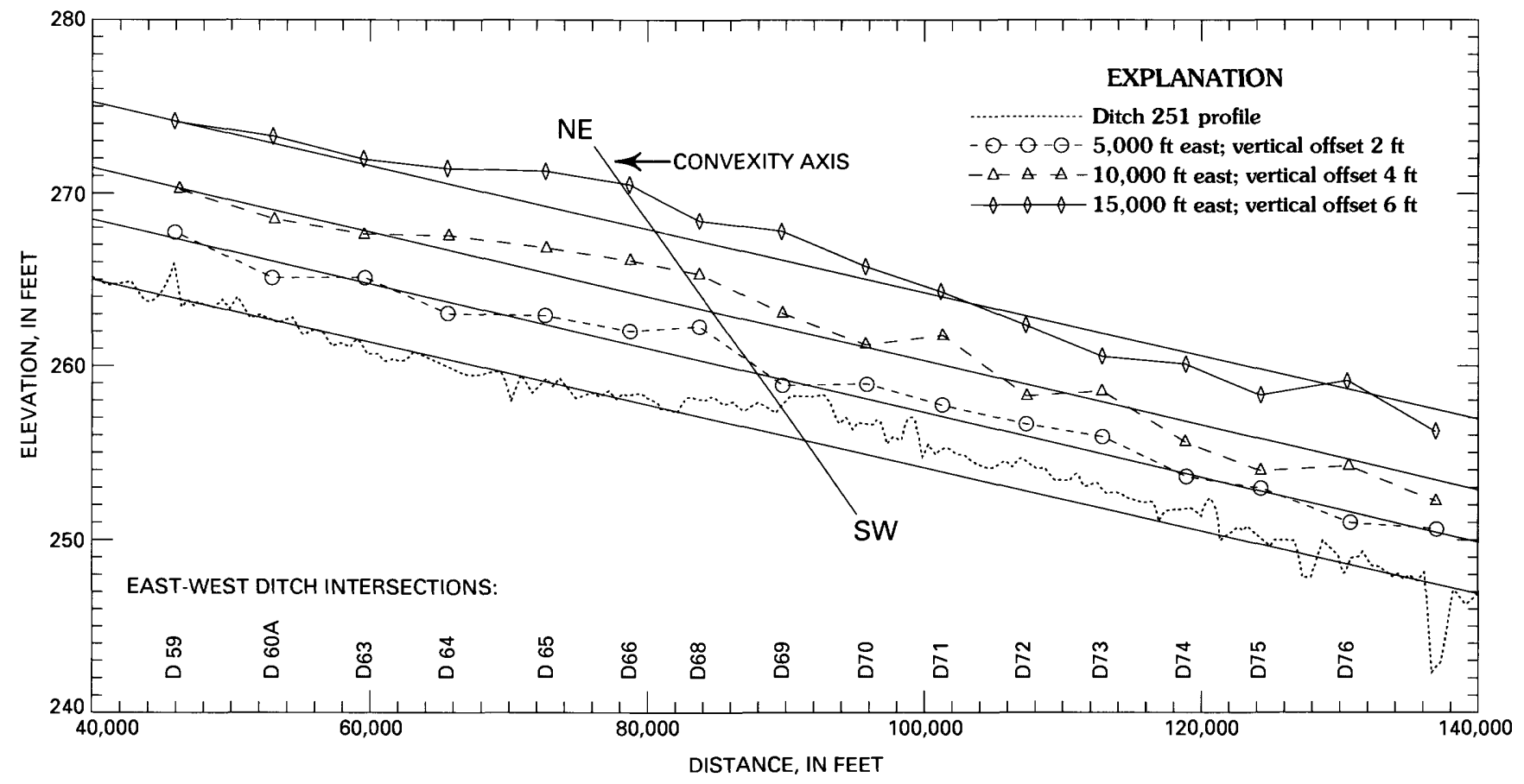

Figure 28. Profile of Ditch 251 and constructed parallel profiles to east, showing regional convexity. 


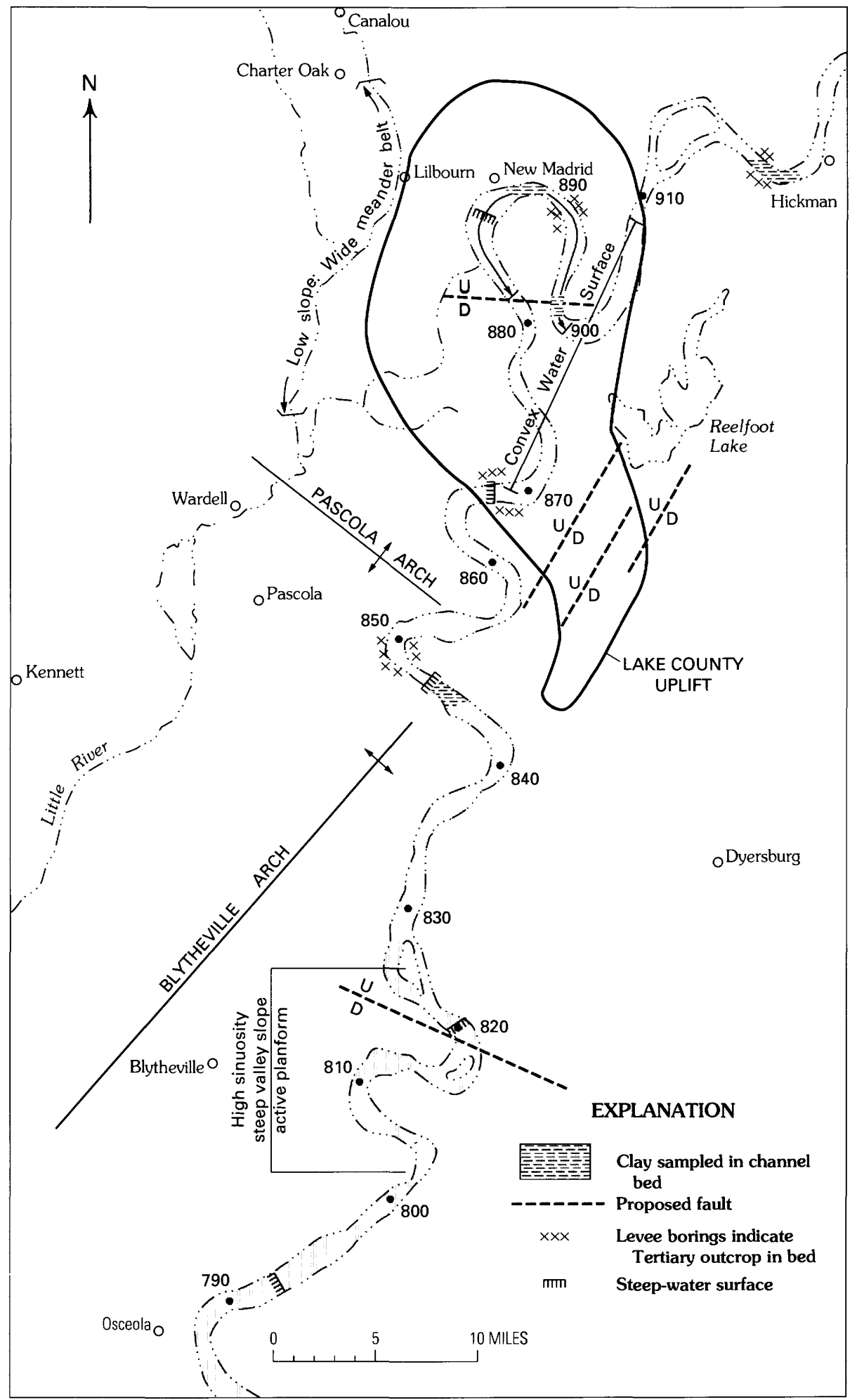

Figure 29. Map showing previously identified structures and anomalous geomorphic conditions along Mississippi River. Locations of geologic structures are from Russ (1982), O'Connell and others (1982), and Heyl and McKeown (1978). 


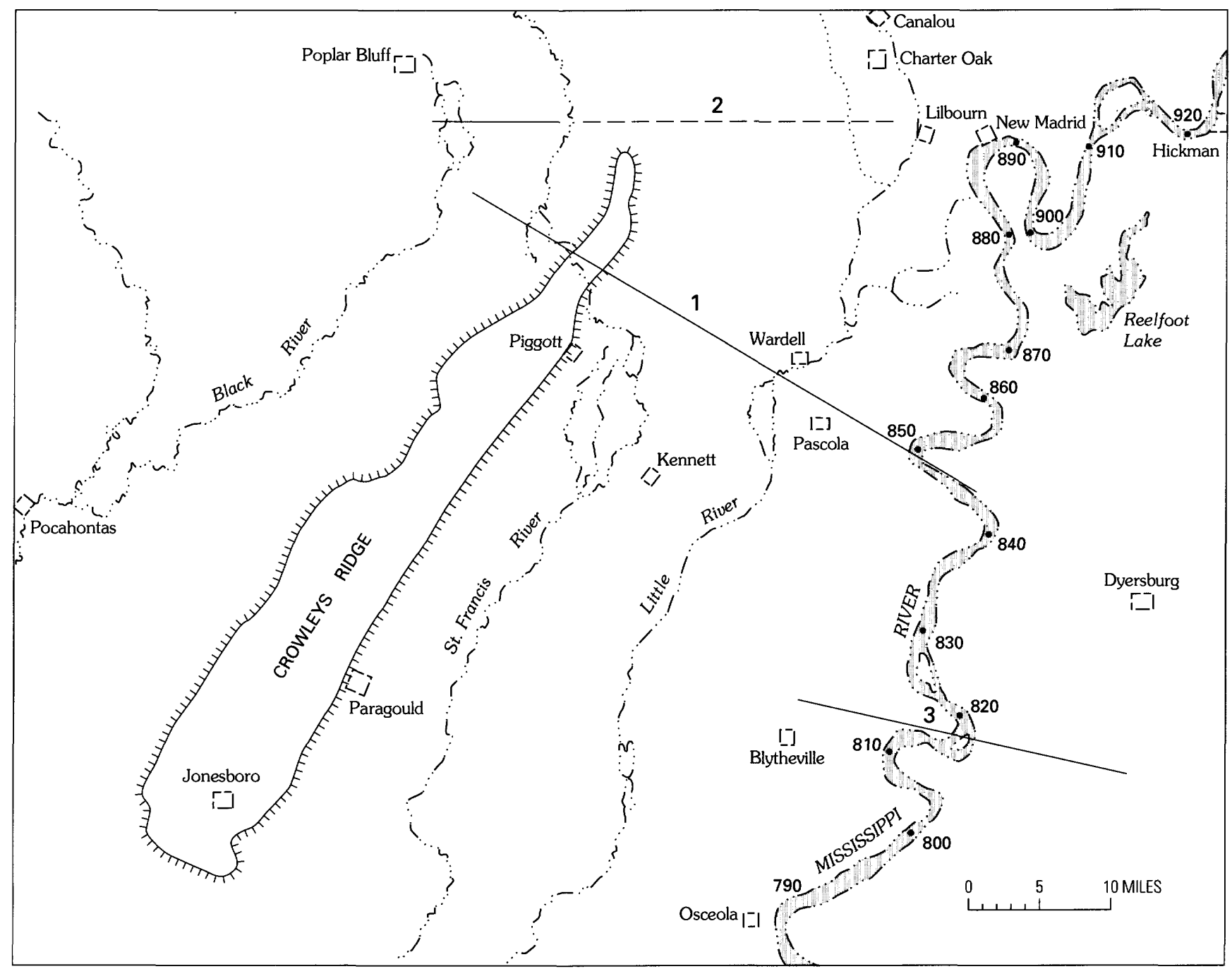

Figure 30. Map showing probable structural trends (numbered lines are discussed in text).

be affected by Tertiary-age sediments that overly the Pascola arch and Blytheville arch (figs. 14 and 29).

Locations of intense seismic activity during 1811-12, as well as recent seismicity, can be related to reaches of anomalous channel morphology. Where the cross-rift seismic trend crosses the river (fig. 2), the river is anomalously wide (fig. 9), shallow (fig. 8), and apparently laterally unstable. The high width-to-depth ratio (fig. 10) is the result of rapid lateral channel migration of the downstream limb of the New Madrid bend, where seismic activity is intense. Convex water-surface profiles (fig. 11) along the New Madrid bend suggest that there has been recent uplift of the New Madrid bend itself. Resistant clay, which is probably of Tertiary age, has been sampled in the bed of the river within the New Madrid bend, suggesting that further channel incision into the uplifted block may be limited. In general, high-flow channel morphology shows the overall pattern of the Lake County uplift, whereas low-flow data depict the effects of more recent subsidiary deformation. For example, low-water profiles (fig. 12) show a steep channel section near New Madrid, Mo., a few miles upstream from where the bed was reported to have been vertically offset in 1811 and 1812 (fig. 29).

Steep water-surface slopes are also present at RM 870 on the downstream margin of the Lake County uplift and at Caruthersville, Mo., and near Osceola, Ark. (figs. 13 and 29). The channel-bed elevation at RM 870 (fig. 13) and at Caruthersville is probably controlled by relatively resistant Tertiary-age clay, as evidenced by levee borings (fig. 14) and bed sampling. Wherever Tertiary units are exposed in the channel bed, the potential for local uplift should be considered, although the top of the Tertiary strata can be highly 
irregular. Levee borings and sampling data indicate exposure of Tertiary units in the channel bed near Hickman, Ky., New Madrid, Mo., and Caruthersville, Mo. (figs. 14 and 29).

Historic river surveys indicate that active deformation of the Lake County uplift has strongly affected the morphology, slope, and course of the Mississippi River in the vicinity of New Madrid, Mo. These variables may provide an effective tool for locating other areas of active deformation in the Mississippi Embayment, but they must be utilized carefully because navigation-improvement projects have strongly impacted channel morphology.

To the west of the Mississippi River, the two major topographic highs, Sikeston Ridge and Crowleys Ridge, appear to be delineated by faults. Crowleys Ridge, between Jonesboro, Ark., and the Castor River, seems to be composed of at least three structural blocks (figs. 15 and 16), and the ridge appears to be bounded by northeast-trending faults.

The Black River, northeast of Pocahontas, Ark., follows a peculiar angular course that suggests fracture control (fig. 17). Other numerous anomalous abrupt changes in direction of the Black, St. Francis, and Little Rivers may be related to subsurface faulting or warping, as well as to differential compaction over structures or the effects of ground-water withdrawal. Nevertheless, many of these anomalies are more than local, and when considered on a larger scale, they suggest major structural trends (fig. 30). For example, between Piggott, Ark., and Pascola, Mo., the St. Francis and Little Rivers flow in eastward arcs, having left abandoned channels to the west. This may be evidence of local uplift and eastward tilting. The Caruthersville bend is due southeast of these features on the Mississippi River. The bend is anomalous, as shown by its long-term stability as an extremely tight bend. The persistence of the bend is apparently due to the exposure of resistant sediments in the channel perimeter, which may be the result of uplift on the northwest-trending Pascola arch or northeast-trending Blythville arch.

The Little River displays course deflections in the vicinity of three structural elements in the New Madrid seismic zone: the western margin of the Reelfoot rift, the axis of the Pascola arch, and the Bootheel lineament (fig. 26). Topographic plots of the area show that natural levee deposits that formed on old Mississippi River crevasse splays have played a significant role in controlling the course of the Little River (fig. 27). For example, the abrupt southern turn of the Little River downstream of Wardell, Mo., occurs as the river emerges from the bounding natural levee deposits. However, ditch profiles that cross the Little River flood plain display a convexity that does not correlate to mapped sedimentologic features (figs. 26 and 28). This presumed upwarp occurs at the point of diversion of the Little River from Big Bayou, an abandoned channel segment to the east. Thus, the avulsion of the Little River to its present course may reflect active uplift at the avulsion point. If so, it may represent a subsidiary feature on the structural trend that extends from the Mississippi
River at Caruthersville, Mo., to the St. Francis water gap near Piggott, Ark. This is shown as trend 1 on figure 30.

Farther north, the St. Francis River and Black River flow in broad eastward arcs, suggesting regional eastward tilting, and the Little River displays a similar arc near Lilbourn, Mo. (fig. 30). Topographic plots of the Little River flood plain in this vicinity (fig. 24) reveal local topographic depressions, which appear unrelated to depositional features and may reflect differential warping on an east-west trend. These anomalies are collectively shown as an east-west trend 2 on figure 30. The Barfield bends of Reach 6 display anomalous geomorphic characteristics and are delineated as trend 3 on figure 30. Within this reach, valley slope is steep (fig. 7), the river channel is highly sinuous (fig. 6) and historic planform maps depict extremely active channel migration and bend development. There is a local steepening of the water-surface profile within the upstream Barfield bend. A fault has been mapped at this location (Heyl and McKeown, 1978); however, subsequent studies have not verified its existence. These trends, plus the segmenting of Crowleys Ridge (figs. 1, 15), appear to represent structural controls on geomorphic features that are normal to the major northeast-southwest structures associated with the Reelfoot rift (fig. 2).

The geomorphic evaluation in this report has identified several anomalous surface features in the New Madrid seismic zone, some of which can be directly linked to mapped structures in the region, primarily the Lake County uplift as delineated by Russ (1982). Of the numerous other features, several suggest that they result from a structural control. The many geomorphic anomalies may reflect a densely fractured suballuvial surface, as in East African rift valleys. Movement on these fractures probably varies in space and time. Although most activity should occur in the seismically active zones (fig. 2), the potential for movement elsewhere is high. The rivers and streams of the Mississippi Embayment are flowing on alluvium, and, therefore, they should be isolated from structural patterns in the underlying Cenozoic rocks. However, the anomalous patterns identified herein suggest that suballuvial structures have a surface expression.

The anomalous geomorphic features delineated in this report have been identified entirely upon compilation of existing topographic and geologic data. Several of the identified anomalies are geomorphically and (or) topographically subtle and require further investigation prior to the adoption of a tectonic explanation for their genesis. However, it is hoped that the identification of these anomalies will aid in the designation of areas where future evaluations of subsurface and surface deformation are warranted.

\section{ACKNOWLEDGMENTS}

This project was funded by the U.S. Geological Survey under the National Earthquake Hazards Reduction Program, Award 14-08-0001-G2119. We gratefully acknowledge the 
advice provided by David Russ, Anthony Crone, and Frank McKeown. During our data-acquisition phase, cooperation provided by Guy Forney, D. Wilbanks, John Monroe, D. Jones, and D. Baretta of the Memphis District Corps of Engineers, Robert Rentschler of the Mississippi River Commission, Larry Dowdy of the Little River Drainage District, Lou Orlowski, Phyllis Steckel, and Roy VanArsdale proved invaluable and is gratefully acknowledged.

The reviews of this report, performed by Anthony J. Crone, Russell L. Wheeler, Roy VanArsdale, and E.S. Schweig, III, were of great value.

\section{REFERENCES CITED}

Brown, B.L., 1971, Soil Survey of Pemiscot County, Missouri: Soil Conservation Service, $47 \mathrm{p}$.

Burnett, A.W., and Schumm, S.A., 1983, Alluvial river response to neotectonic deformation in Louisiana and Mississippi: Science, v. 222, p. 49-50.

Chiu, J.M., Johnston, A.C., and Yang, Y.T., 1992, Imaging the active faults of the central New Madrid seismic zone using PANDA array data: Seismological Research Letters, v. 63, p. 375-393.

Costain, J.K., Bollinger, G.A., and Speer, J.A., 1987, Hydroseismicity-A hypothesis for the role of water in the generation of intraplate seismicity: Geology, v. 15, p. 618-621.

Cox, R.T., 1988a, Evidence of Quaternary ground tilting associated with the Reelfoot rift zone, northeast Arkansas: Southeastern Geology, v. 28, p. 211-224.

1988 b, Evidence of late Cenozoic activity along the Bolivar-Mansfield tectonic zone, Midcontinent, USA: The Compass, v. 65, p. 207-213.

Crone, A.J., and Brockman, S.R., 1982, Configuration and deformation of the Paleozoic bedrock surface in the New Madrid seismic zone, in McKeown, F.A., and Pakiser, L.C., eds., Investigations of the New Madrid, Missouri, Earthquake Region: U.S. Geological Survey Professional Paper 1236, p. 115-136.

Crone, A.J., Harding, S.T., Russ, D.P., and Shedlock, K.M., 1986, Seismic-reflection profiles of the New Madrid seismic zone, data along the Mississippi River near Caruthersville, Missouri: U.S. Geological Survey Miscellaneous Field Studies Map, MF-1863.

Federal Emergency Management Agency, 1990, Map Index Flood Insurance Rate Map, New Madrid County, Missouri.

Ferguson, D.V., and Gray, J.L., 1971, Soil Survey of Mississippi County, Arkansas: Soil Conservation Service, $58 \mathrm{p}$.

Fisk, H.N., 1944, Geological investigation of the alluvial valley of the lower Mississippi River: Vicksburg, Mississippi River Commission, $78 \mathrm{p}$.

Fuller, M.L., 1912, The New Madrid Earthquake: U.S. Geological Survey Bulletin 494, $119 \mathrm{p}$.

Guccione, M.J., Lafferty, R.H., III, and Cummings, L.S., 1988, Environmental constraints of human settlement in an evolving Holocene alluvial system, the lower Mississippi valley: Geoarchaeology, v. 3, p. 65-84.
Hamilton, R.M., and Zoback, M.D., 1982, Tectonic features of the New Madrid seismic zone from seismic-reflection profiles, in McKeown, F.A., and Pakiser, L.C., eds., Investigations of the New Madrid, Missouri, Earthquake Region: U.S. Geological Survey Professional Paper 1236, p. 55-82.

Heigold, P.C., 1991, Crustal character of the Illinois Basin, in Leighton, M.W., Kolata, D.R., Oltz, D.F., and Eidel, J.J., eds., Interior Cratonic Basins, American Association Petroleum Geologists Memoir 51, p. 247-261.

Heyl, A.V., and McKeown, F.A., 1978, Preliminary seismotectonic map of central Mississippi Valley and environs: U.S. Geological Survey Miscellaneous Field Studies Map, MF-1011, scale 1:500,000.

Hildenbrand, T.G., Kane, M.F., and Hendricks, J.D., 1982, Magnetic basement in the upper Mississippi Embayment region-A preliminary report, in McKeown, F.A., and Pakiser, L.C., eds., Investigations of the New Madrid, Missouri, Earthquake Region: U.S. Geological Survey Professional Paper 1236, p. 39-53.

Hildenbrand, T.G., Rosenbaum, J.G., and Reynolds, R.L., 1992, High resolution aeromagnetic study of the New Madrid seismic zone: A preliminary report: Seismological Research Letters, v. 63, p. 204-221.

Howard, A.D., 1967, Drainage analysis in geologic interpretation: A summary: Bulletin of the American Association Petroleum Geologists, v. 51, p. 2246-2259.

Jin, D., and Schumm, S.A., 1987, A new technique for modeling river morphology, in Gardner, V., ed., International Geomorphology, Chichester, John Wiley, p. 681-690.

Johnston, A.C., 1982, A major earthquake zone on the Mississippi: Scientific American, v. 246, p. 60-68.

Kelson, K.I., VanArsdale, R.B., Simpson, G.D., and Lettis, W.R., 1992, Assessment of the style and timing of late Holocene surficial deformation along the central Reelfoot scarp, Lake County, Tennessee: Seismological Research Letters, v. 63, p. 349-357.

King, J.E., 1978, New evidence on the history of the St. Francis Sunk Lands, northeastern Arkansas: Geological Society of America Bulletin, v. 89, p. 1719-1722.

Kolata, D.R., and Nelson, W.J., 1991, Basin-forming mechanisms of the Illinois Basin, in Leighton, M.W., Kolata, D.R., Oltz, D.F., and Eidel, J.J., eds., 1991, Interior Cratonic Basins, American Association Petroleum Geologists Memoir 51, p. 287-292.

Little River Drainage District [LRDD], 1989, The Little River Drainage District of southeast Missouri, 1907-Present: Cape Girardeau, Missouri, Little River Drainage District, 13 p.

Luzietti, E.A., Kanter, L.R., Schweig, E.S., III, Shedlock, K.M., and VanArsdale, R.B., 1992, Shallow deformation along the Crittenden County fault zone near the southeastern boundary of the Reelfoot rift, northeast Arkansas: Seismological Research Letters, v. 63, p. 263-276.

McGinnis, L.D., 1963, Earthquakes and crustal movement as related to water load in the Mississippi valley region: Illinois State Geological Survey Circular 344, 20 p.

McKeown, F.A., 1982, Overview and discussion, in McKeown, F.A., and Pakiser, L.C., eds., Investigations of the New Madrid, Missouri, Earthquake Region: U.S. Geological Survey Professional Paper 1236, p. 2-14. 
McKeown, F.A., Jones-Cecil, Meridee, Askew, B.L., and McGrath, M.B., 1988, Analysis of stream-profile data and inferred tectonic activity, eastern Ozark Mountains region: U.S. Geological Survey Bulletin 1807, 39 p.

McKeown, F.A., Hamilton, R.M., Diehl, S.F., and Glick, E.E., 1990, Diapiric origin of the Blytheville and Pascola arches in the Reelfoot rift, east-central United States: Relation to New Madrid seismicity: Geology, v. 18, p. 1158-1162.

Nelson, K.D., and Zhang, J., 1991, A COCORP deep reflection profile across the buried Reelfoot rift, south-central United States: Tectonophysics, v. 197, p. 271-293.

Nuttli, O.W., 1982, Damaging earthquakes of the central Mississippi valley, in McKeown, F.A., and Pakiser, L.C., eds., Investigations of the New Madrid, Missouri, Earthquake Region: U.S. Geological Survey Professional Paper 1236, p. 15-20.

Obermeier, S.F., 1989. The New Madrid earthquakes: An engineering-geologic interpretation of relict liquefaction features: U.S. Geological Survey Professional Paper 1336-B, 114 p.

O'Connell, D.R., Bufe, C.G, and Zoback. M.D., 1982, Microearthquakes and faulting in the area of New Madrid, Missouri-Reelfoot Lake, Tennessee, in McKeown, F.A., and Pakiser, L.C., eds., Investigations of the New Madrid, Missouri, Earthquake Region: U.S. Geological Survey Professional Paper 1236, p. 31-38.

Penick, J., Jr., 1981, The New Madrid Earthquakes of 1811-1812: Columbia, Mo., University of Missouri Press, 181 p.

Russ, D.P., 1982, Style and significance of surface deformation in the vicinity of New Madrid, Missouri, in McKeown, F.A., and Pakiser, L.C., eds., Investigations of the New Madrid, Missouri, Earthquake Region: U.S. Geological Survey Professional Paper 1236, p. 95-114.

Saucier, R.T., 1970, Origin of the St. Francis Sunk Lands, Arkansas and Missouri: Geological Society America Bulletin, v. 81, p. 2847-2854.

1977, Effects of the New Madrid Earthquake series in the Mississippi alluvial valley: Vicksburg, Miss., U.S. Army Engineers Waterways Experiment Station, Soils and Pavements Laboratory, Miscellaneous Paper S-77-5, 10 p.

1987, Geomorphological interpretations of late Quaternary terraces in western Tennessee and their regional tectonic implications: U.S. Geological Survey Professional Survey Paper 1336-A, 19 p.

Schumm, S.A., 1986, Alluvial river response to active tectonics, in Wallace, Robert, ed., Active Tectonics: Studies in Geophysics: Washington, D.C., National Academy Press, p. 80-94.

Schumm, S.A, Mosley, M.P., and Weaver, W.E., 1987, Experimental Fluvial Geomorphology: New York, John Wiley, 413 p.

Schumm, S.A., Rutherford, I., and Brooks, J., 1994, Pre-cutoff morphology of Mississippi River between Cairo and Old River, in Schumm, S.A., and Winkley, B.R., eds., The Variability of Large Alluvial Rivers: New York, American Society of Civil Engineers Press, p. 13-44.
Schwalb, H.R., 1982, Paleozoic geology of the New Madrid area: U.S. Nuclear Regulatory Commission, NUREG, CR-2909, $61 \mathrm{p}$.

Schweig, E.S., III, and Marple, R.T., 1991, Bootheel lineament: A possible coseismic fault of the great New Madrid earthquakes: Geology, v. 19, p. 1025-1028.

Schweig, E.S., III, Marple, R.T., and Li, Y., 1992, An update of studies of the Bootheel lineament in the New Madrid seismic zone, southeastern Missouri and northeastern Arkansas: Seismological Research Letters, v. 63, p. 277-284.

Schweig, E.S., III, Shen, F., Kanter, L.R., Luzietti, E.A., VanArsdale, R.B., Shedlock, K.M., and King, K.W., 1992, Shallow seismic reflection survey of the Bootheel lineament area, southeastern Missouri: Seismological Research Letters, v. 63, p. 285-296.

Shedlock, K.M., and Harding, S.T., 1982, Mississippi River seismic survey: Geophysical Research Letters, v. 9, p. 1275-1278.

Stahle, D.W., VanArsdale, R.B., and Cleaveland, M.K., 1992, Tectonic signal in bald cypress trees at Reelfoot Lake, Tennessee: Seismological Research Letters, v. 63, p. 439-447.

Stauder, William, 1982, Present-day seismicity and identification of active faults in the New Madrid seismic zone, in McKeown, F.A., and Pakiser, L.C., eds., Investigations of the New Madrid, Missouri, Earthquake Region: U.S. Geological Survey Professional Paper 1236, p. 21-30.

Suter, C.R., 1878, Report to the Secretary of War: House of Representatives 45th Congress, Volumes II and III.

VanArsdale, R.B., Schweig, E.S., Kanter, L.R., Williams, R.A., Shedlock, K.M., and King, K.W., 1992, Preliminary shallow seismic reflection survey of Crowleys Ridge, northeast Arkansas: Seismological Research Letters, v. 63, no. 3, p. 309-320.

VanArsdale, R.B., Stahle, D., and Cleaveland, M., 1991, Tectonic deformation revealed in bald cypress trees at Reelfoot Lake, Tennessee: Report prepared for Division of Engineering, Office of Nuclear Regulatory Research, U.S. Regulatory Commission, Contract No. NRC-04-90-111, 12 p.

Walsh, J., 1966, Geologic map of the Eldama Ravine-Kabarnet area: Mines and Geological Department, Government of Kenya.

Wilbanks, D.C., 1991, Subsidence within the Memphis District: Tectonic movement or subsidence?, in U.S. Army Corps of Engineers 1991 Surveying Conference,, July 16-18, 1991, Louisville, Kentucky, p. 7B-1-7B-7.

Zernitz, E.R., 1932, Drainage patterns and their significance: Journal of Geology, v. 40, p. 598-521.

Zoback, M.D., 1979, Recurrent faulting in the vicinity of Reelfoot Lake, northwestern Tennessee: Geological Society America Bulletin, v. 90, p. 1019-1024.

Zoback, M.D., Hamilton, R.M., Crone, A.J., Russ, D.P., McKeown, F.A., and Brockman, S.R., 1980, Recurrent intraplate tectonism in the New Madrid seismic zone: Science, v. 209, no. 4460, p. 971-976. 




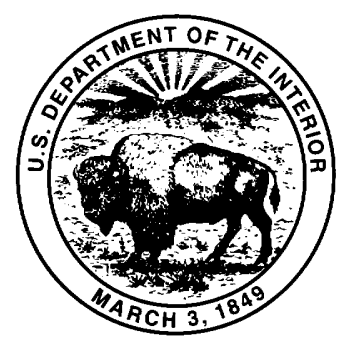

